Historic, archived document

Do not assume content reflects current scientific knowledge, policies, or practices. 


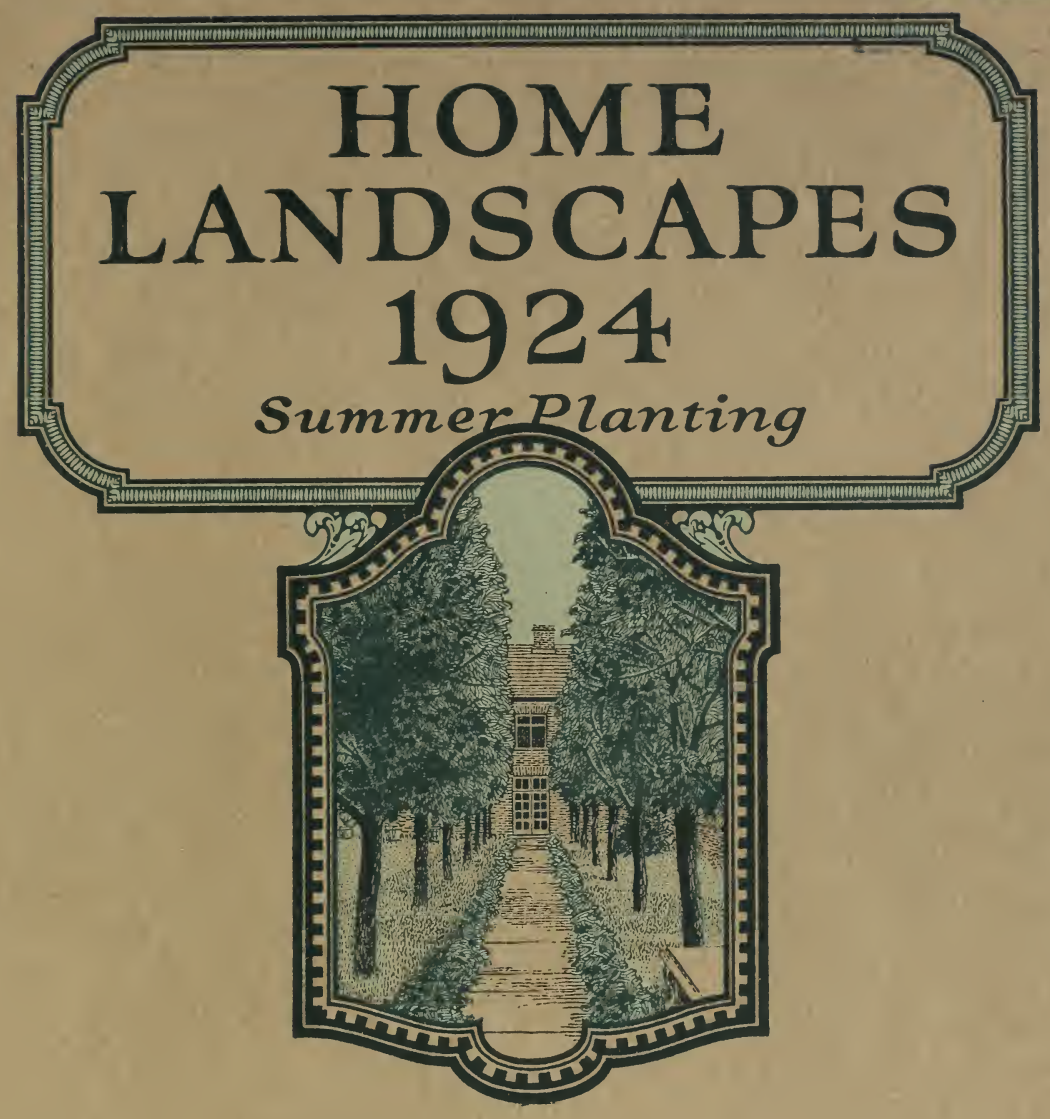

\section{HICKS NURSERIES \\ I. HICKS \& SON \\ Westbury, Long Island}





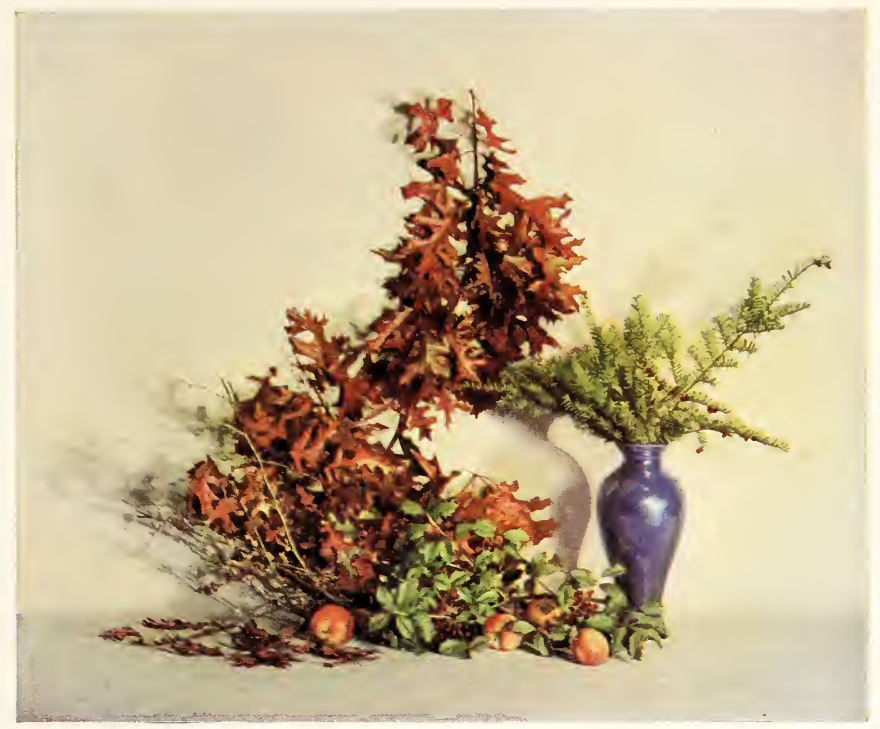

\title{
HOME LANDSCAPES, 1924 SUMMER PLANTING
}

\author{
By Henry Hicks
}

앙

CONTENTS

A Slccessful Large Garden

The Bacon Gardens

A Successful Siall Gardex

Why WAIT ?

Shade Trees

Plannixg the Landscape

Evergreen Trees

The All-Year Landscape

Broad-Leaved Evergreens
Flowering Shrubs . . . . . . . 49

Vines. . . . . . . . . 59

New and Rare Plants. . . . . . . 60

Roses and Climbing Roses . . . . . 63

Hardy Garden Flowers . . . . . 65

Plant all Slimer . . . . . . . 7 i

Plantateria (help yolrself). . . . . 72

Frutts . . . . . . . . . 73

Large Tree Moving . . . . . . . . 79

GLARANTEE-We guarantee every iree and plant from the nursery to grow satisfactorily, or replace free.

IIe prefer you to plant. Transportation and planting of replaced stock is borne by the purchaser

TERUS-Prices are for stock loaded at the nursery. Estimates furnished on delivery and planting or

freight or express. 5 at 10 rate. 50 at 100 rate. Packing free, except for stock of unusual size

\section{HICKS NURSERIES}

I. HICKS \& SON

WESTBURY, LONG ISLAND 


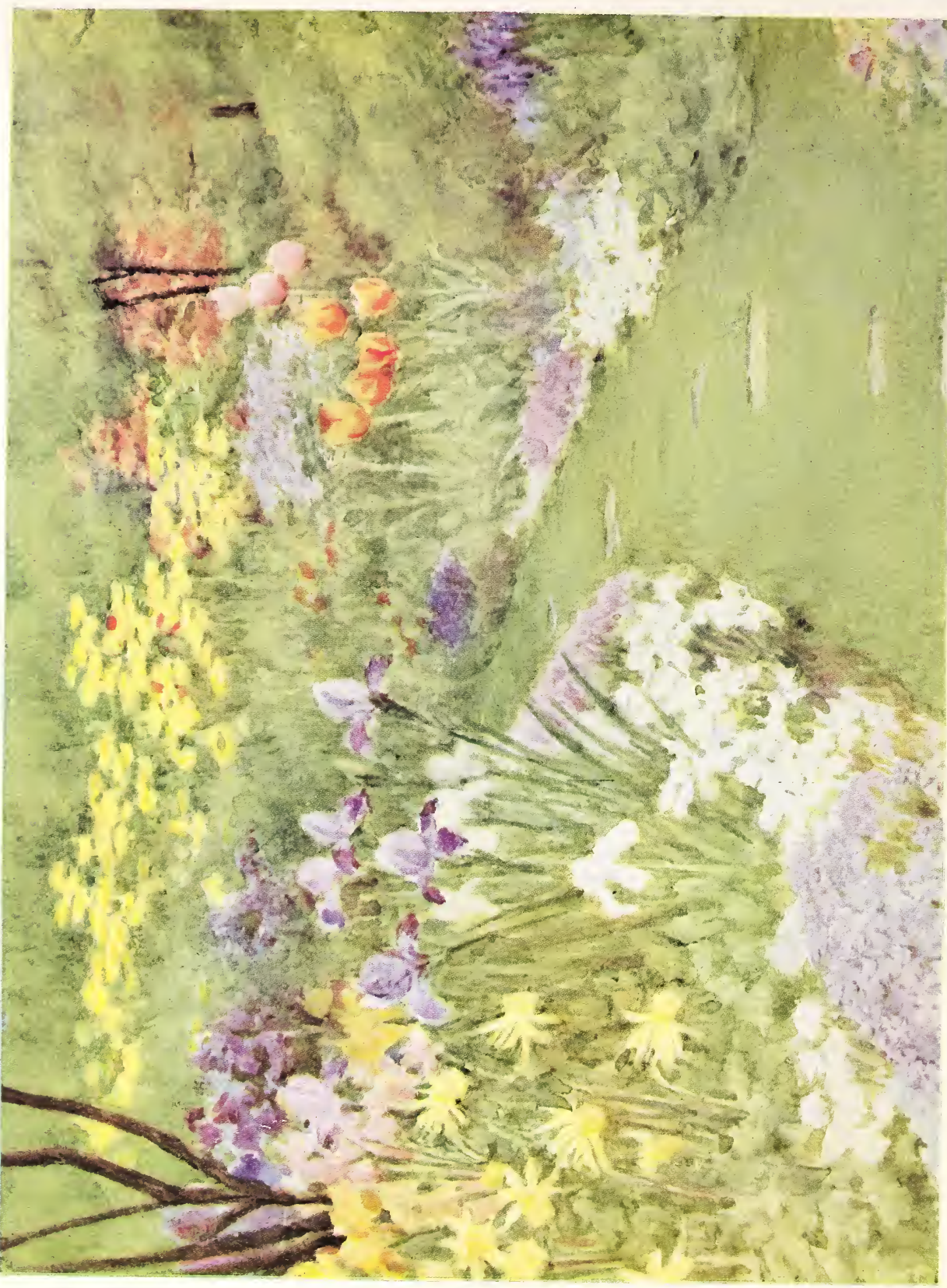




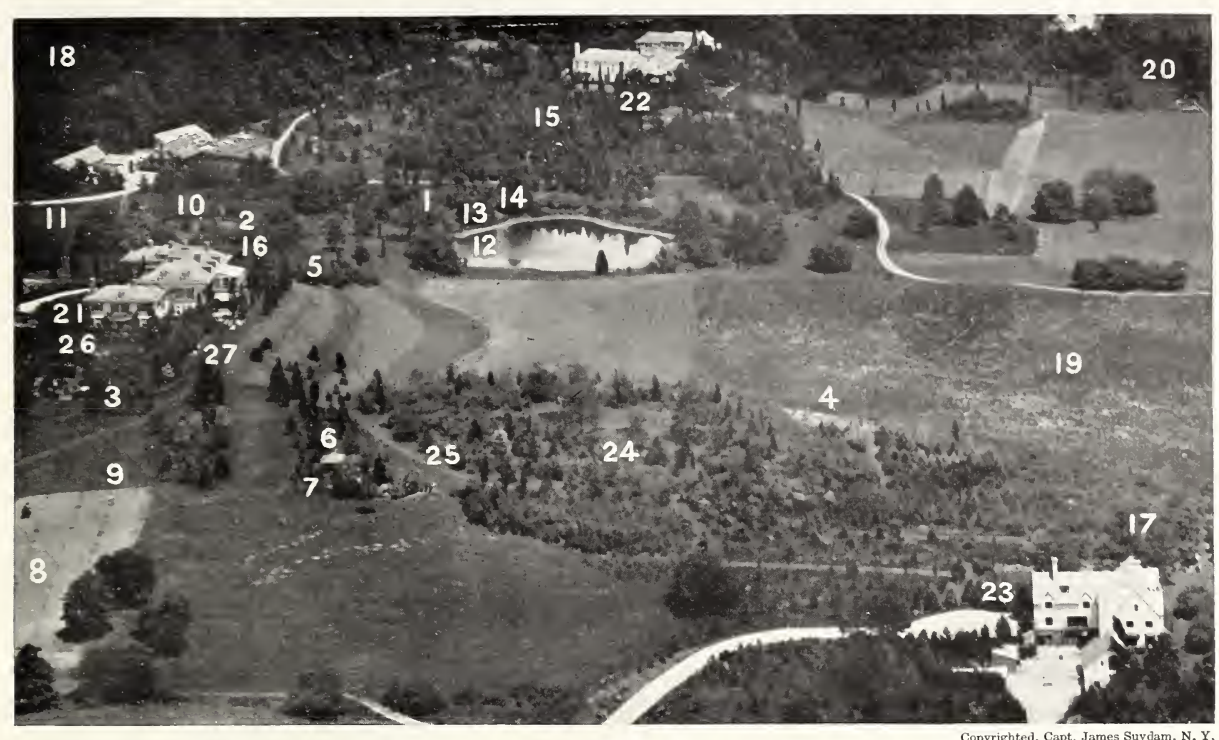

Airplane view of the estate of Mrs. Robert Bacon (21); of her son, Congressman Robert L. Bacon (22); and son-in-law, Mr. George Whitney (23) The numbers refer to the three paintings by Miss Amy Cross and the sketches. See also pages $3,5,7,8$ and 9

\section{A SUCCESSFUL LARGE GARDEN}

\section{By Henry Hicks}

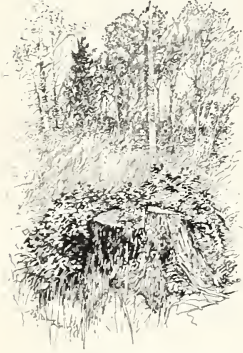

12. A stump garden in the Bluetts or Quaker Lady, Pearlwort and Ferns wildflower sanctuary. On this
old stump are Partridge Berry,

HE greatest beauty of civilized landscape is well-used farmland with its orchards, grain fields and pastures. Some farm regions, like the Bacon place, have achieved it through the growth of centuries.

It was the custom to leave the crest of the hills and the steepest slopes forested. The farmland was divided by fences of locust posts and chestnut rails into fields of ten or more acres for the rotation of wheat, hay, pasture, corn and oats. Along the fences grew an occasional Oak, Hickory, Sassafras or Cedar. Capable farmers prided themselves upon the clean appearance of their hedge rows, but many Wild Cherries did creep in.

With the change from dairy to market gardening and from market gardening to large estates, most of the fences have been taken down, leaving long open sweeps of meadow, the first essential of good landscape. The eye delights to travel down such vistas to restful focus in the distance. Landscape gardening is not dotting shrubs; it is sun, sky and breezeway. The highest pleasure is looking over your own well tilled fields-not "I have spent a hundred thousand dollars on this grading and wall around the house." To enjoy and improve the general landscape of your home grounds is one of the first essentials of landscape gardening. Arranging the fields, gardens, orchards and buildings is the first step.

The big meadow (I9) is the central feature of the landscape on the Bacon estate. The main house (21) faces it in the center; the residence of the son, Congressman Robert L. Bacon (22), is on the east, that of the son-in-law, Mr. George F. Whitney (23), on the west. The three homes 


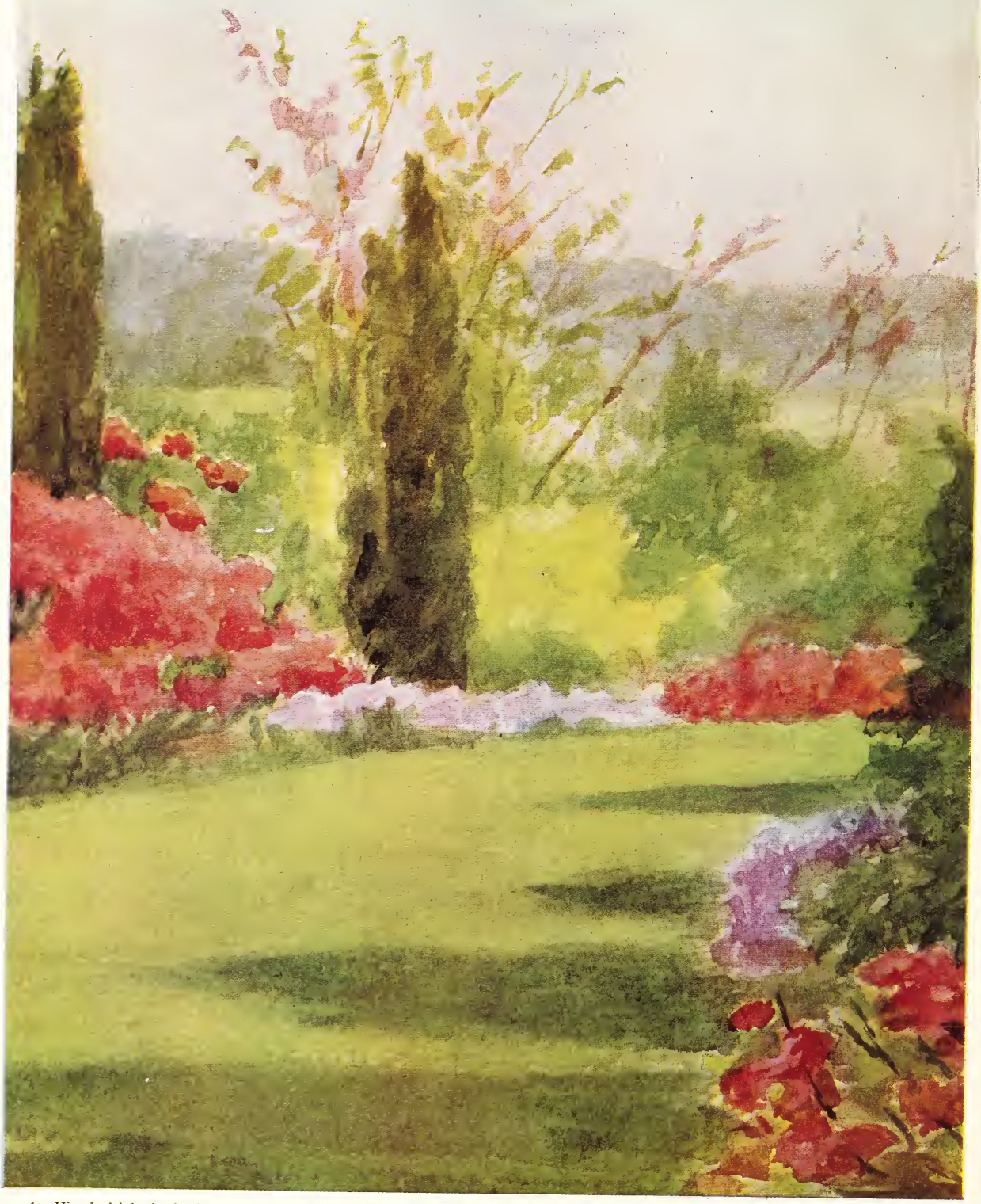
4. Hinodegiri Azalea in the Bacon Garden. The lavender is Phlox laphami. The pink tree is Red Bud. The narrow tree is Cedar. These
were thinned out of the bird sanctuary 
share the same broad meadow, the breezeway from the ocean and the protection of the windbreak (I8) at the north. Each, on its separate hill, is separated from the next by a plantation of Pine and Oak (15, 24). They are connected by smooth grass paths $(25,15)$, dipping into the valleys and up again. On the rolling fields Hay, Corn, Rye, Potatoes and Cow-beets succeed one another according to the best farm practice under the management of Miss Miller, whose home is in the old Titus homestead once used by Hessian soldiers. The old farm buildings are used for cattle; in the orchard is a modern poultry plant. On the level portion of the farm bordering the Hempstead plains is a field for polo practice; on the West and South a Pine and Oak border along the road, shown on page $3 \mathrm{I}$.

\section{() 0}

Now for the details - for the Bacon place has details, each one a lesson for small place or large place; for the man with money or the one with only a shovel, a basket, and a love of beauty. This is not one of the big estates where there has been extravagant expenditure; it has been honestly developed, using big trees where necessary and economical small young plants where they would serve the purpose. Above all, it embodies the personal ideas and good taste of its owners-Mrs. Bacon says, "I decide what to do and ask Professor

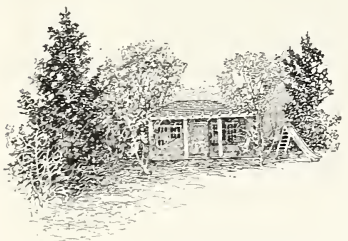

6. A house for school and play; embowered with Japanese Double Flowering Cherry and Christmas tree Sargent if it is all right."

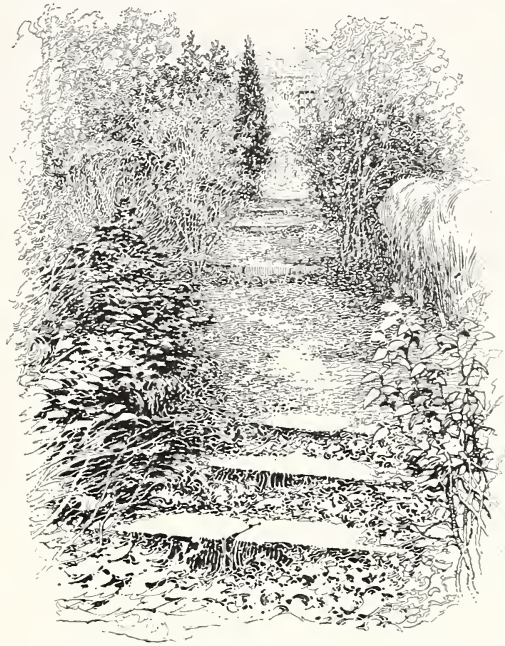

5. Inkberry is a broad leaved evergreen of the Holly family. Professor Sargent says it is the hardiest broad leaved evergreen for New England. The Abelia is wrapped in burlap for winter. This is a shrub with pink wrapped in burlap for winter. This is a shrub with pink killed, but it will bloom anyway. With this wrapping up killed, but it will bloom anyway. Wit

The stone steps that keep the path from being too steep are made from old flag stones set in cement with pockets of soil under the cracks. Little rock plants peep out of the crevices and hang on the sides. A spirit of content-
ment pervades all parts of the garden even the places that are not mowed

Her ability to put the right plant in the right place, where it is happy ever after, is a great help to realize and hold her ideals.

\section{THE AZALEA PATH \\ (Illustrated on page 4)}

During the war these plants were crowded in the bird sanctuary. They grew and were ready to burst forth like a butterfly when the owner's interest could turn back to gardening from raising money for the American Ambulance in Paris. In those anxious days of work and anxiety, little work was done in the garden, but that work helped in renewing strength to support the ambulance.

This path was laid out where it is easy to walk along the hill below the sanctuary. It was an easy matter to bring over a few Azaleas, add some little Cedars to frame a view of the pond, silhouette against the sky a few Red Bud trees, border the path with Phlox laphami. The planting may look a little bit widely spaced, bare ground may show, but this is not important - there may be bare ground beyond in the cornfield. Bare ground invites little Azaleas and Rhododendrons to be tried out. A border of Blueberry and many other shrubs will give the birds a bite as they fly from group to group.

The Azalea Hinodegiri belongs to a large family from Japan. The Japanese love them, they get variations, propagate them more than other people. We may not understand the symbols of their garden design, the meaning of their miniature mountains, stepping stones and pools but we can understand and use their flowers. The Azaleas from Japan culminate in brilliant carmine red, varying from this peak, which is welcome in the cool days of early spring, to the palest pink and white. Another series goes through the lavenders and magenta to purple, another series through the yellows to orange. You will see the varieties and various colors shown here in harmony.

Plants of Azalea and its relatives can be shifted around in full bloom. There is no need for majenta or orange to clash.

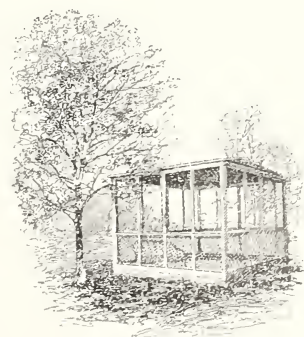

7. Next to the play house is a sand box enclosed with a wire screen. The sturdy Red Oak gives shade. It was moved in as a big
tree with a large ball of earth 


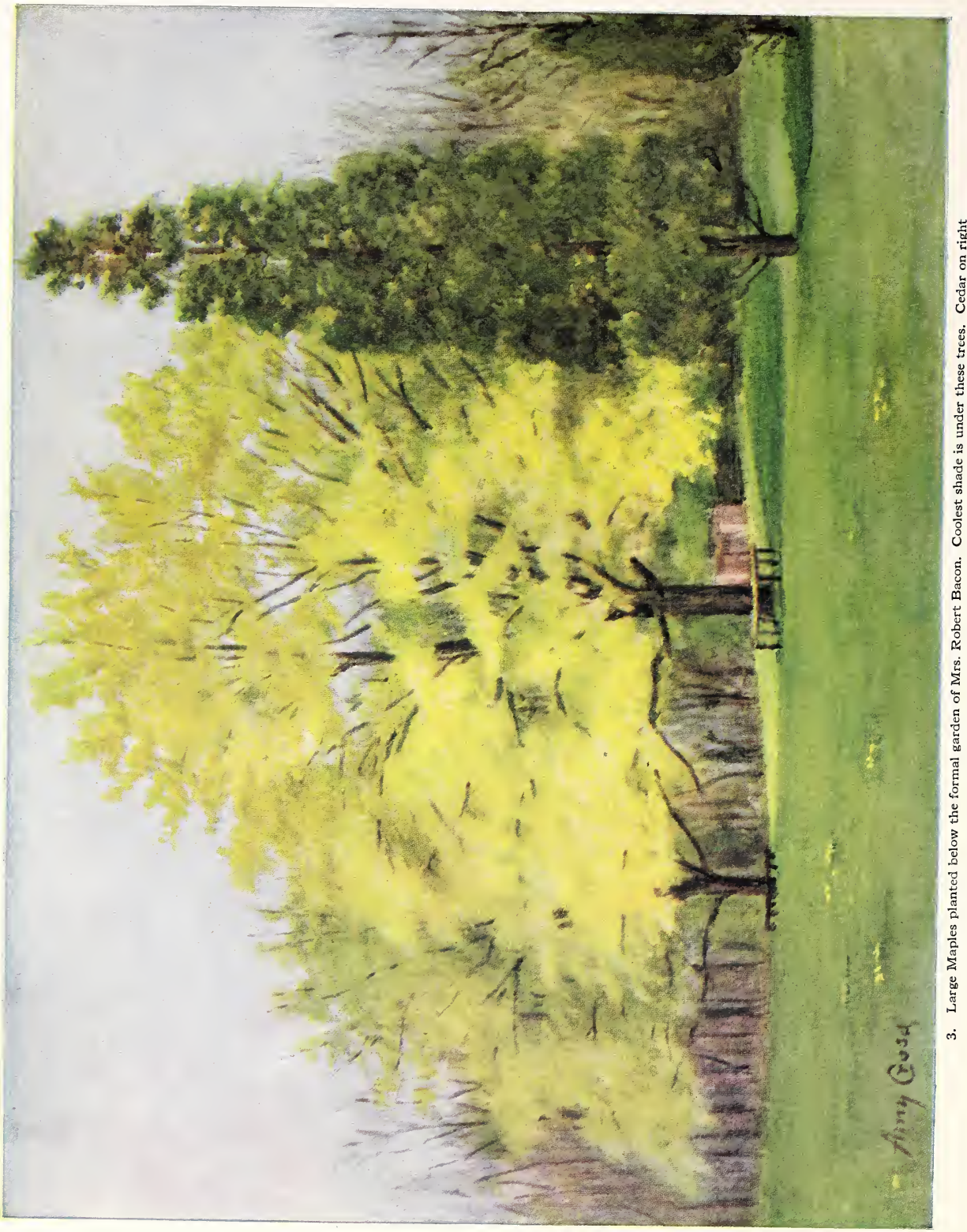




\section{THE BIRD SANCTUARY}

Between the residences of Mrs. Robert Bacon and Mr. Geo. Whitney there was a wind-swept hill (24), once so bleak and bare, so windy and hungry, that the birds could find no shelter and

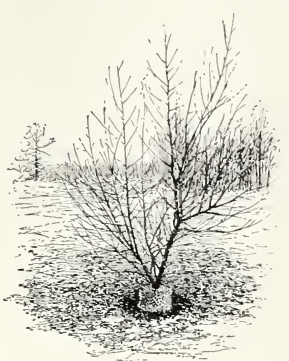

8. This Peach tree is branched low to avoid breakage and help in picking. There is a strip of half inch mesh wire netting around the trunk to keep the rabbits from gnawing the bark. A little later back

but little food. Now it is a-twitter any time of the year, because there is wind shelter, hawk protection by thorny bushes, food from berries and food in bird feeding stands - cracked grains and suet. How has this been accomplished?

First, some large Pines on the estate were moved. They were then sixty years old. They were but the nucleus. Other Pines, Spruce, Fir and Cedars were planted especially as a windbreak from the northwest. An under planting of Dogwood, Laurel, Azalea, Beach Plum Arrowwood, Prairie Rose, Elderberry, Bittersweet, Judas, Cotoneaster or Quince Berry, and many other berry bearing plants make a wildwood tangle.

There is an idea that such a planting costs lots of money and needs a great deal of care. It can cost money if the trees are large. It need not cost much if the plants are small-the birds don't care. 'The care for the first year was to run a water pipe (9) through the grass and attach a hose so that trees and plants could be given a drink once or twice a month during the first part of the summer. Plant some of the things Nature would plant; group them together for mutual protection as Nature would, give them a drink to help overcome the shock of transplanting, pull out the biggest robbers among the weeds, then let Nature take its course for two or three years.

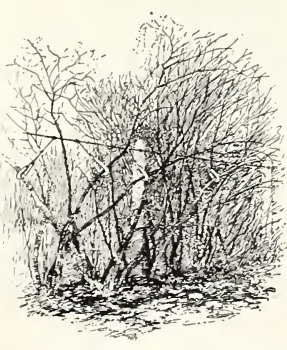

10. The Lilac hedge gets broken by the wind. The branches are fastened to the post and wire by wire and rubber hose. The is the complete gardener gardener who sees a trouble of

\section{THE YELLOW MAPLES}

To balance the house and frame in the west end of the garden and to permit this view to the hills, these two large Maples were planted. They are pictured here in the first flush of spring bloom. They ellow blossoms, brightest just at dandelion time, pass so quickly few people remember them. The main value of these Maples is coolness. The gardener says, "The nurse and children find this tree the coolest place in summer. The foliage seems to attract and hold the breeze, like a canopy."

\section{THE CHILDREN'S GARDEN}

Just north of the bird sanctuary and looking across at the Holly is a little playhouse (7) and schoolhouse (6) and the children's garden. Everything is in scale. The garden is small. The children can plant and hoe if they like and not fear they are interfering with the big folks' garden. It is a place to go of one's very own. It does not have to be kept in order-undoubtedly the gardener helps a bit. Grandmother brings packages of seeds and new plants from her garden. There is a series of children's gardens and playhouses.

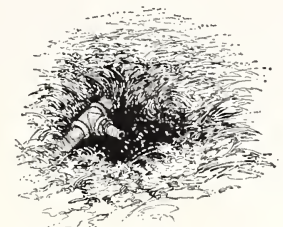

9. Why the trees grow. A water pipe below the ground. The gardener said, "If it is on top of the ground it interferes with mowing. We plowed a furrow and put it underground. We know the lowest point and drain it out in the winter. At this " $T$ ' we can attach a hose" 


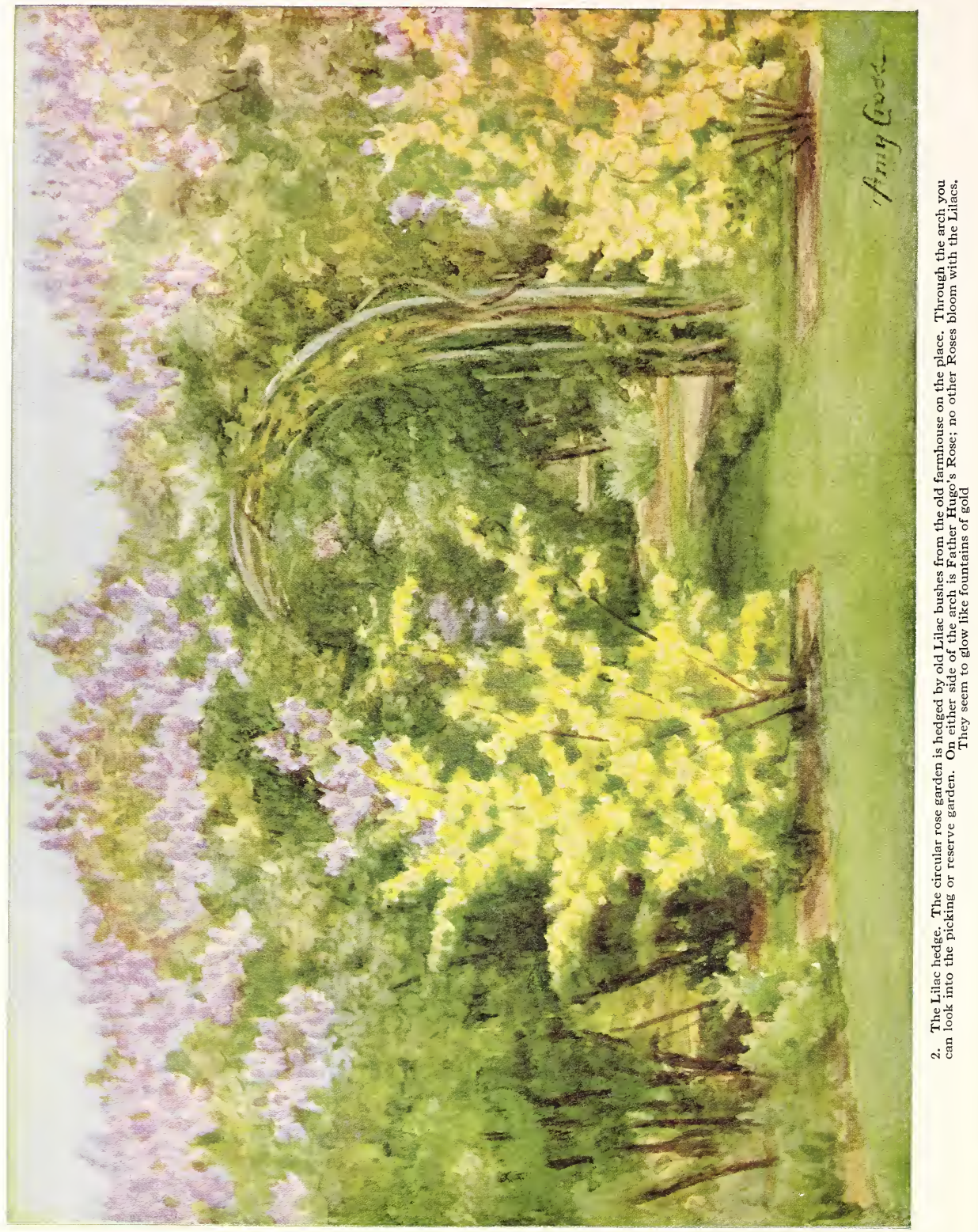




\title{
THE BACON GARDENS
}

\author{
Described by MISS AMY CROSS Landscape Painter \\ "Two Paradises are in one \\ To live in Paradise alone."
}

$\mathrm{F}^{R}$ ROM some forgotten corner of my memory this curious old couplet flasbed into my mind after a long day spent in the beautiful garden of Mrs. Robert Bacon, at Westbury, L.I. It came in answer to the thought "Why! I bave not spoken to, or even seen, a buman being, and yet, bow completely bappy I bave been!"

The weather had been so perfect on that lovely day in early June and after my morning's work was finished, I bad wandered at will over the long stretches of grassy fields and lawns, or through flower bordered or wooded paths in search of new subjects for my brush, coming every now and then upon some charming vista, or new beauty of blossoming shrub or fruit trees.

For many days I had worked in this garden, from the time when

$$
\begin{aligned}
& \text { "Each flower and herb on earth's dark brest } \\
& \text { Rose from the dreams of it's wintry rest." }
\end{aligned}
$$

Until now, when the early summer bad come. Spring in the country was not new to me-many times in long past seasons, I bad gatbered the fragrant Arbutus from under frosted brown leaves in the forests, and searcbed the wooded billsides for the first Hepaticas and star-like Anemones or the meadows for Violets and Cowslips-but never before bad I seen its gradual unfolding where Nature and Art bad combined to bring so many lovely things together in such a luxury of color and fragrance.

And the wild things bad their place there too, for Mrs. Bacon bas preserved as far as possible the natural beauty of ber grounds, and one almost forgets in going through them, the amount of thought and time and labor that have been expended to bring forth this satisfying and barmonious whole.

I shall always feel it to bave been a great privilege to spend so many bours there with my palette and brushes, for it often seemed, indeed, a Paradise, although not always one in which I was alone. Sometimes my work lay near the children's corner and plavground, and I beard their bappy voices mingling with the songs and twitterings of the birds; or again a nurse or governess with a number of little ones as lovely as the flowers themselves, would pass by my easel, and pause a moment for a friendly greeting or kindly comment on my. painting. Also the gardener and bis assistants would often be at work nearbr, and occasionally there were visitors. But again there were days when all the refulgent beauty of the out-of-doors seemed just for me. I am never lonesome with Nature - the trees are my friends, the flowers seem to talk to me, and the birds and bumming insects are my orchestra - and so satisfied bave I always

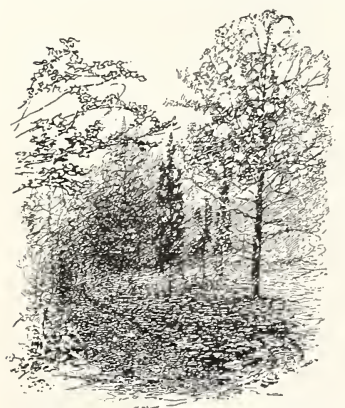

15. Path through the Oak and Pine grove to the residence of Congressman Robert L. Bacon. These were planted as little trees on a bare windswept hill. They have taken care of themselves been with the wild flowers of the fields and woods that I bave never craved a garden of my own, but I bave learned to understand through my friends, the pleasure that may be derived from one-and often most, from the small intimate gardens, where every individual plant is watched with loving care, and without which no country bome, no matter bow small, need be. A tinv patch of ground can be transformed into "a thing of beauty" by one who loves flowers and is willing to give up a little time to them.

\footnotetext{
"A garden is a lovesome thing, God wotRose plot Fringed pool

Ferned grot-

The veriest school

Of peace; and yet the fool

Contends that God is not-

Not God in gardens! when the eve is cool? Nay, but I have a sign:

'Tis very sure God walks in mine."
}
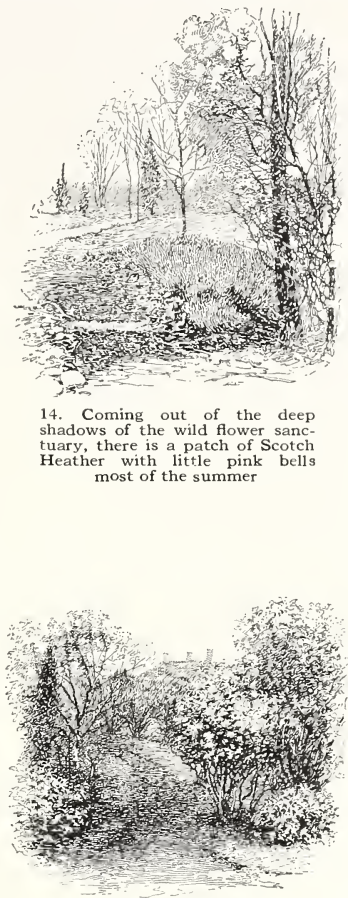

16. The path up the hill from the Rose garden. It is through a grove of tall shrubs such as Mock Orange, Dogwood and Judas. The shiny plants in the right and left foreground are Leucothoe, a relative of the Laurel. Beside the path are Paeonies and Lilies

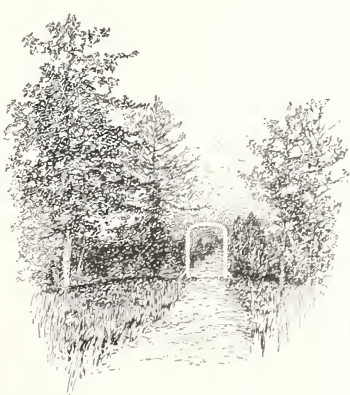

17. A grove of Pin Oaks on a hill separating the residence of Mrs. Bacon from the residence of $\mathrm{Mr}$. Whitney. By the arch there is another children's garden 


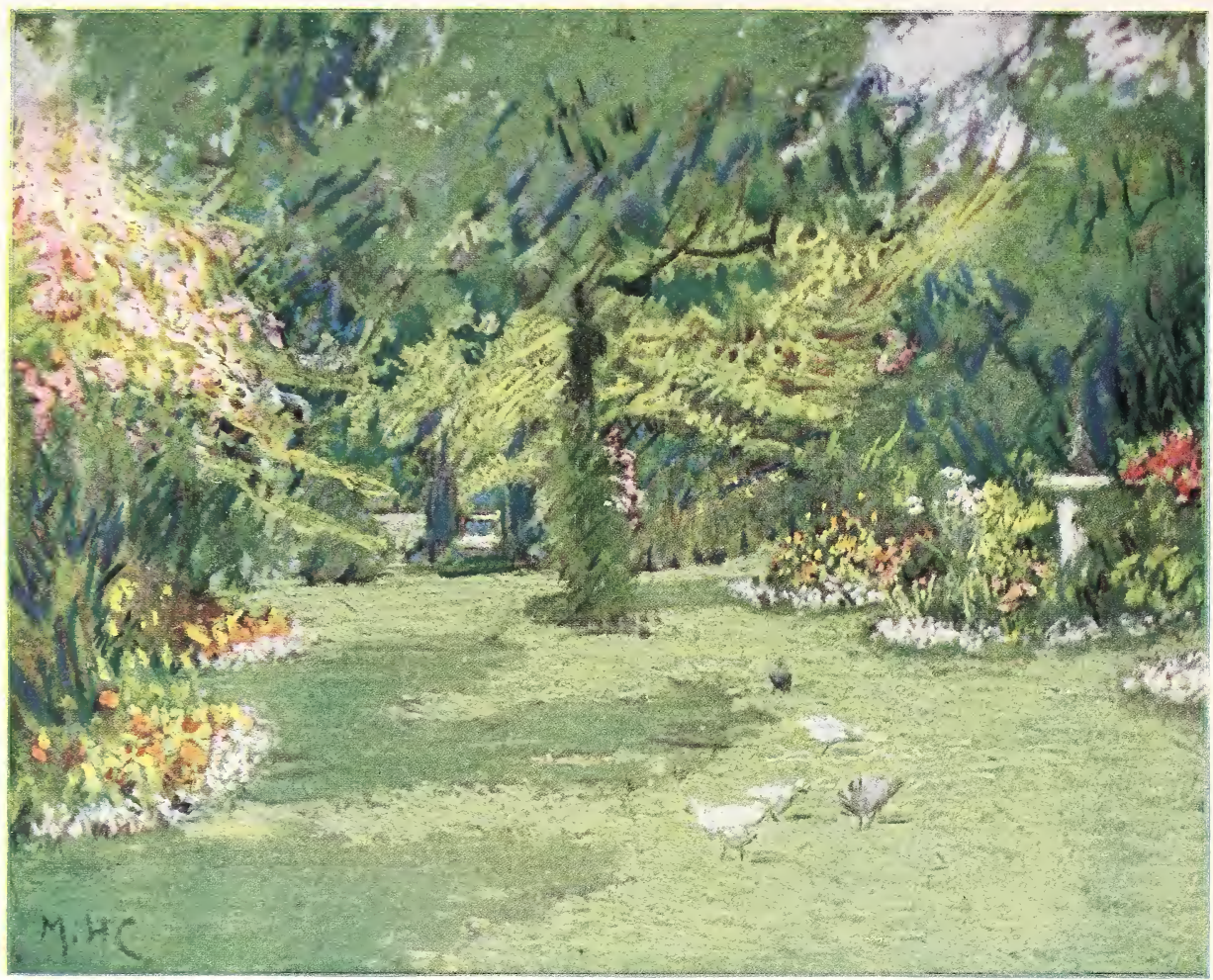

A Successful Small Place-The Harris Place, Westbury

\section{HOW MR. HARRIS DEVELOPED HIS PLACE}

He looked for a balf acre of land where it is not expensive. He found it between Grantrille and New Cassel, two developments in Westbury. Across the road are the coal pockets and ice plant, oil tanks and swimming pool. The railroad track is near. He shuts them all out with a wall of green. The birds like it and be likes it. I saw three or four species of birds that I bad not seen in that vicinity for several years. Probably the reason ther were there is thev were sure of a drink and a bath. This part of Westbury is over a mile from a pond or stream, and the bird-bath is welcome. The picture was taken from $A$ looking toward $B$. This is in a little side lawn between the entrance drive and the south border. $C$ is the poultry bouse. The garage is at the back of the poultry bouse. Between the garage and the bouse is a square gravel court. D represents the rows of Apple, Pear, Plum and other fruit trees. At $E$ are Currant busbes and other berries. IT ben the fruit trees were voung vegetables were grown between, now the area is given over to poultry.

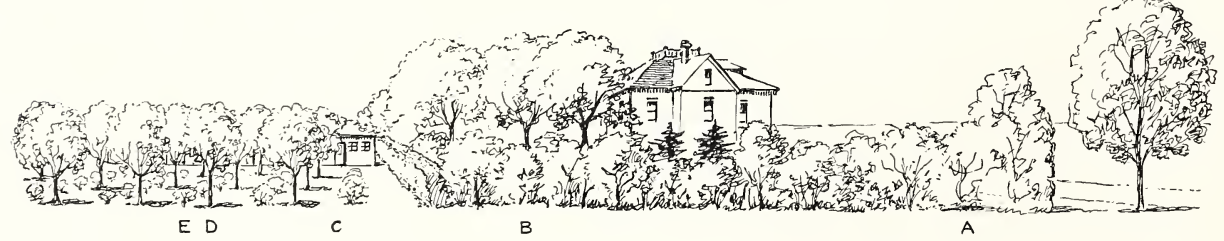




\section{A SUCCESSFUL SMALL PLACE}

\section{By Henry Hicks}

$M^{\prime \prime}$

R. HARRIS is an expert mason and plasterer. He has half an acre of ground at Westbury. His house is white stucco on cement blocks. It is a good warm house in winter, cool in summer, needing no expensive repairs due to decay or wearing off of paint.

Mrs. Harris says: "When Mr. Harris comes home from work, he does not come in the house right away, but stays out in the garden watching the birds." Asked when he filled the bird-baths, she answered: "In the morning before he goes to work."

Not everybody loves the garden as much as that. It is possible to have a good garden if you hire somebody one day a week in summer to take care of it. It is also possible and much more interesting to have a good garden if you are willing to do the work yourself.

Mr. Harris has planned his place carefully, to get as much fun and food as possible. Each little area is treated differently, according to its purpose. The house is on the north side, the garage in the rear, with a square gravel service court where the clothes-line is hung when necessary.

The entrance drive is on the south side of the house, and in front is a little square semi-formal garden, with rectangular flower beds, bordered with a thick tangle of flowering shrubs backed up by a Privet hedge.

Across the drive, to the south, is the lawn shown in this picture. The pink mass is a bower of Dorothy Perkins Roses; the yellow is Nasturtiums; the white border Sweet Alyssum. The big shade-trees in the background shut off the orchard and poultry yard. A vine covers the trunk of the big tree in the center. Only six feet of shrubbery separates the bird-bath on the right from the graveled service court - just enough to make a dark background for the picture and a dense thicket for the birds.

The flower-bed around the bird-bath, bordered with Sweet Alyssum, contains Sweet Williams, Petunias, Geraniums, and whatever else a flower lover would tuck in.

In the rear is an orchard, with rows of Apples, Pears, Peaches and Black Currants. When the trees were young, vegetables were grown between them, but now the orchard is enclosed with wire and enjoyed by the chickens while the little seedlings are started. Afterward, as the picture shows, the fowls are allowed to ramble around the place, where they can do little damage and pick up much food.

Mr. Harris is a catalogue reader. He loves to pick out some new and rare shrub and make room for it in his garden even if some common Privet or Deutzia has to be junked. In a shady out-ofthe-way corner a few flats contain experiments with seeds from far and near.

If your place is not already a beauty-spot like his, why not make it so? You can do it gradually if you like-extend it over spring and fall or even over several seasons, spending fifteen or twenty dollars at a time and adding one unit after another. Or if you want to make one job of it, tell us what you feel inclined to spend-perhaps twenty-five dollars, perhaps two hundred-and let us help you invest it to the best advantage. Whatever you buy from us is guaranteed to grow satisfactorily. 


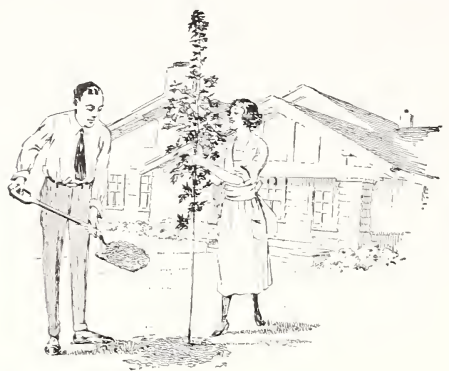

Little trees like this or a group of them for quick shade can be planted at low cost. They can be carried on your running board and planted as illustrated in full leaf in mid-summer and give shade immediately

\section{WHY WAIT?}

$\checkmark$ IME-SAVING is the greatest material achievement of the age. In transportation, merchandising, manufacturing and education it is being carried out. Food from orchards, shade from broad trees, shelter and screens from tall evergreens and big shrubs are yours from Hicks Nurseries. Why Hicks methods are successful you will see from the series of pictures and inscriptions along the bottoms of pages $22-28,34-36,3^{8-4} \mathrm{I}$ and the large tree moving department on page 79 .

In 1870 Edward Hicks, son of Isaac Hicks, who founded the nursery in 1853 , was moving large trees for the arboretum of Charles A. Dana, editor of the New York Sun and A. T. Stewart, founder of Garden City. His inventive genius developed several new machines and patents for agriculture and moving of large trees. Training foremen and expert men to dissect out, protect and plant wide spreading roots or to handle large balls of earth is of equal or greater importance. We have the knowledge and the courage to tell you what is best and worth your while and this knowledge will save you time and money.

The margin shows how Hicks Nurseries have grown the trees for you. Without realizing it when we started, the soil has two advantages mentioned in the Soil Survey of Long Island by the United States Department of Agriculture. Sandy loam produces a great abundance of small fibrous feeding roots near the surface, easy to dissect out. The tap roots do not readily penetrate the subsoil of sand and gravel and it is easy to pull off the ball of earth.

Quick selection is easy at Hicks Nurseries and quick delivery is practical most of the year by a staff of expert men and a fleet of trucks.

It is possible to obtain plants you wish to take with you in your automobile. Some are ready in pots, others are temporarily planted or heeled in ready to pull up; others can be dug for you in a reasonable time. You can arrange to call or send for them later.

The prices are reasonable. They are grown and dug so they can be guaranteed to grow satisfactorily.
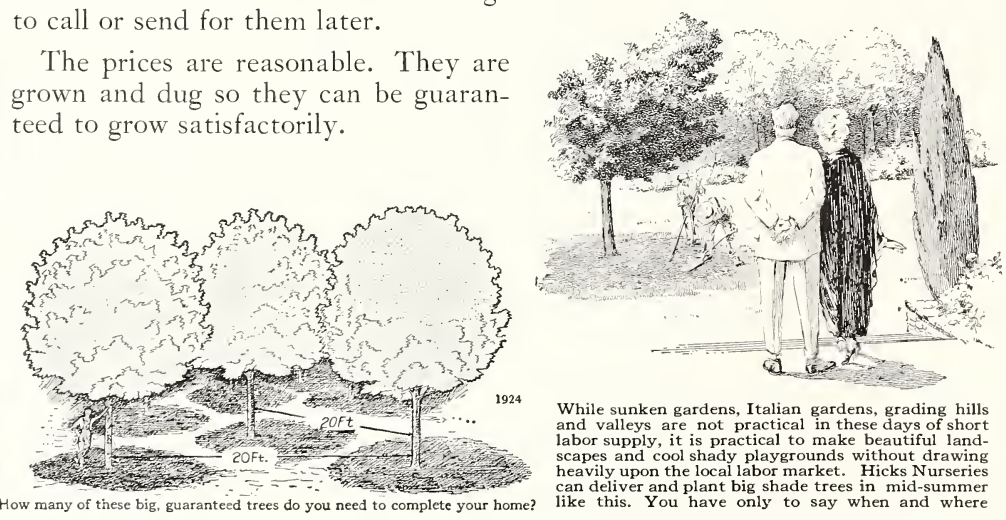

While sunken gardens, Italian gardens, grading hills and valleys are not practical in these days of short labor supply, it is practical to make beautiful landscapes and cool shady playgrounds without drawing scapes and cool shady playgrounds without drawing heavily upon the local labor market. Hicks Nurseries can deliver and plant big shade trees in mid-summer 


\section{Section I \\ SHADE TREES \\ [Deciduous]}

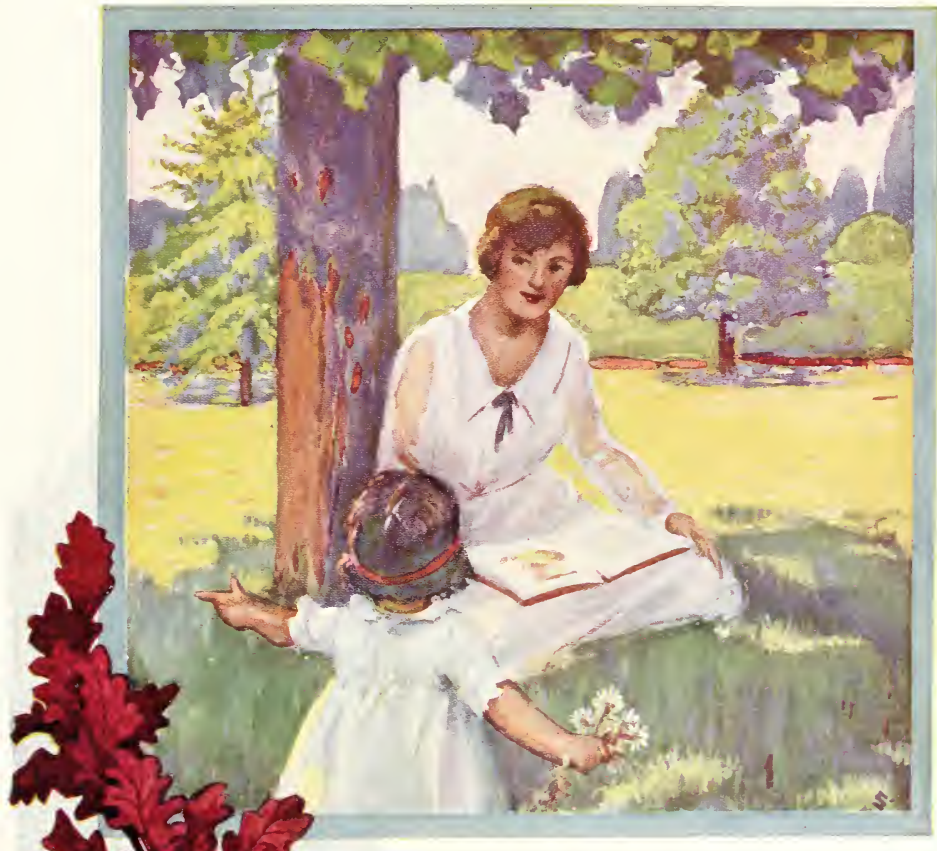

The desire of every man's heart is a comfortable place for the family. You can plant such a tree any week in the year. If you wish it in fune or Fuly in full leaf, it is yours. The size of the trunk is not important. You can have the same cool shade with three trees at $\$ 25.00$ that might cost three times as much if in one tree.

Foliage of White Oak in autumn 


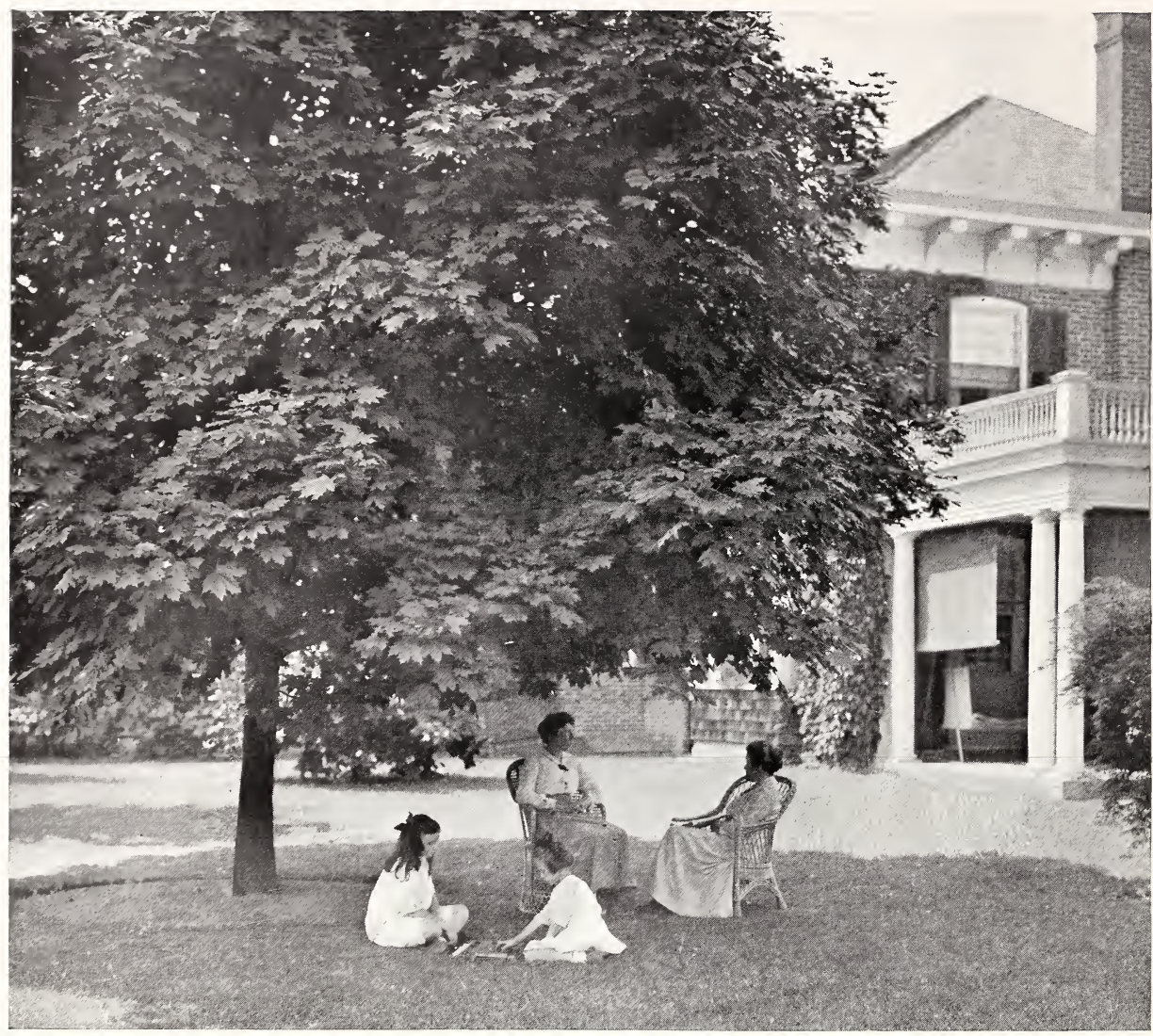

Large Maple planted on lawn of Mr. F. D. Jackson, Plandome, L. I. A large proportion of the places in this community have been planted with large trees from the Hicks Nurseries. Plandome never went through the "awkward age." It was always attractive.

First: Because the plots were large enough to have lawns of their own surrounded by their own trees and gardens.

Second: The streets fitted the contour of the land.

Third: The house sites were arranged to get a good view of Manhasset Bay.

Fourth: They were arranged and planted to receive the cool southerly sea breezes.
Trees like these are more important than the porch shades and many other items now considered essential in building. Mr. Jackson built several houses, planted them with trees like this and sold them.

On the borders of his own place he planted big broad trees instead of the usual hedge and low shrubs. The result was that where tall foliage was needed to shut out neighboring buildings, they were shut out immediately; where there should be a dip in the foliage to let in breeze or for a distant view, the foliage was low. The deep shadows and rounded contours of broad trees made immediately a beautiful home landscape instead of the usual raw new appearance of little trees.

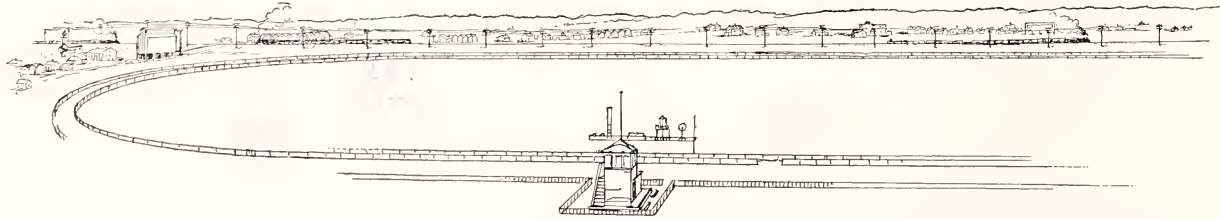

Belmont Park before planting was not a restful, rural scene, but railroad tracks, trains, coal pockets, telegraph poles and houses. The trees were mostly planted in January by the Hicks system of mulcining the ground to prevent freezing. Look up the advantages of winter 


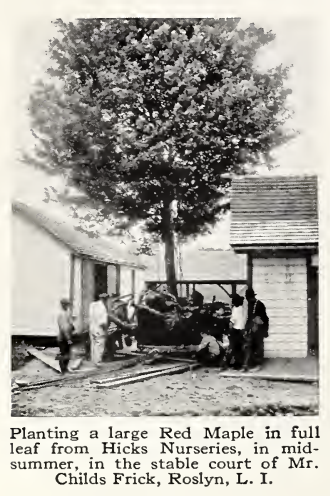

\section{PLANNING THE LANDSCAPE}

W

HEN you look at pictures of old and beautiful homesteads, is not their principal attraction the noble trees surrounding them-the big round mass of dark green foliage in front, behind, or at the ends? If you wish such a home, plant trees.

Every house needs a frame, a setting; some big, broad trees-Maples perhaps, or Lindens, Oaks or Beeches. Not only for outside appearance, but for the view from within, and the comfort their shade affords

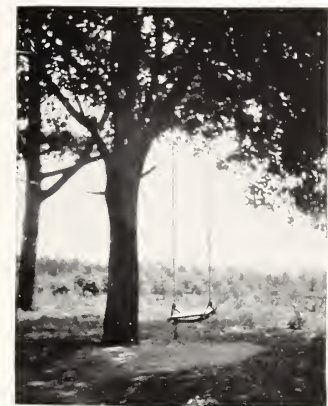

Large Maple in Hicks Nurseries. There are hundreds of trees with branches all ready for swings for the children

your family and friends. Low branched trees make an ideal playground for the kiddies.

We cannot, offhand, describe your tree needs or suggest the particular trees to satisfy them. Take photographs of your place, or sketch out the way you would like it to look. Perhaps a group or grove of trees flanking the house at each end will be best. A group is better than just one at each end; three or four trees will arch over and make a tall, shaded retreat, cooler and more comfortable than if each stands separate in a circle of shade. Perhaps, however, your place is too small for more than one large tree. Consult a landscape architect. Ask us for a list of members of the American Society of Landscape Architects.

In any case, do not place trees so that any rooms are shaded all the time; the sun should shine into every room part of the day. Do not crowd; if the tree you select is now twenty-five feet wide, allow space for it to grow to thirty-five, and place it twenty or thirty feet from the house. The other trees can have less space allowed for them, especially if you wish the effect of a grove.

Decide whether you want the branches high to let the breeze under, or low so that they will hang to the ground. You can have them branched at five, seven, nine or twelve feet, and most of the trees at Hicks Nurseries are trained so they can be trimmed higher.

Come to the Nursery, look around and have the fun of selecting as well as designing your own landscape.

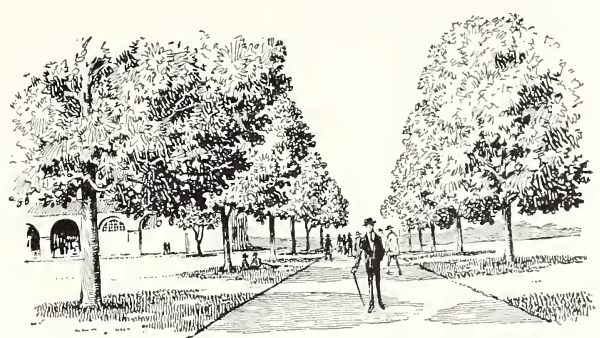

Large Maple trees from Hicks Nurseries planted east of grandstand at Belmont Park. These grew so successfully that next year orders were given for the plantation below

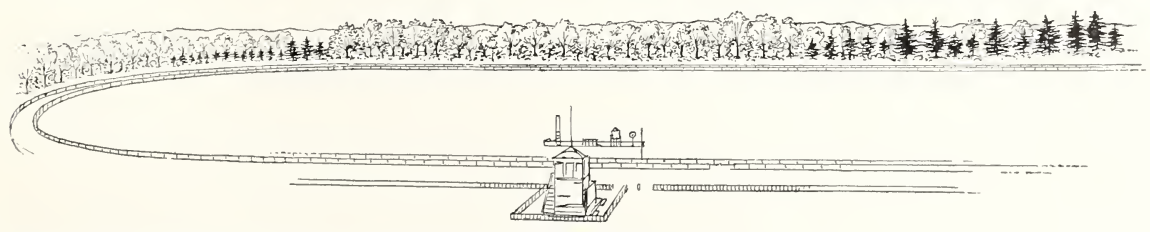

After a boundary of Hicks time-saving trees were planted, the Belmont Park Race Track was enclosed by a beautiful border of foliage-Pines, Maples, Lindens, Oaks; many of which have been growing in the Nursery twenty to thirty years. They were in perfect condition to transplant, and they have carried out the guarantee of satisfactory growth or free replacement by a new tree loaded at the Nursery 

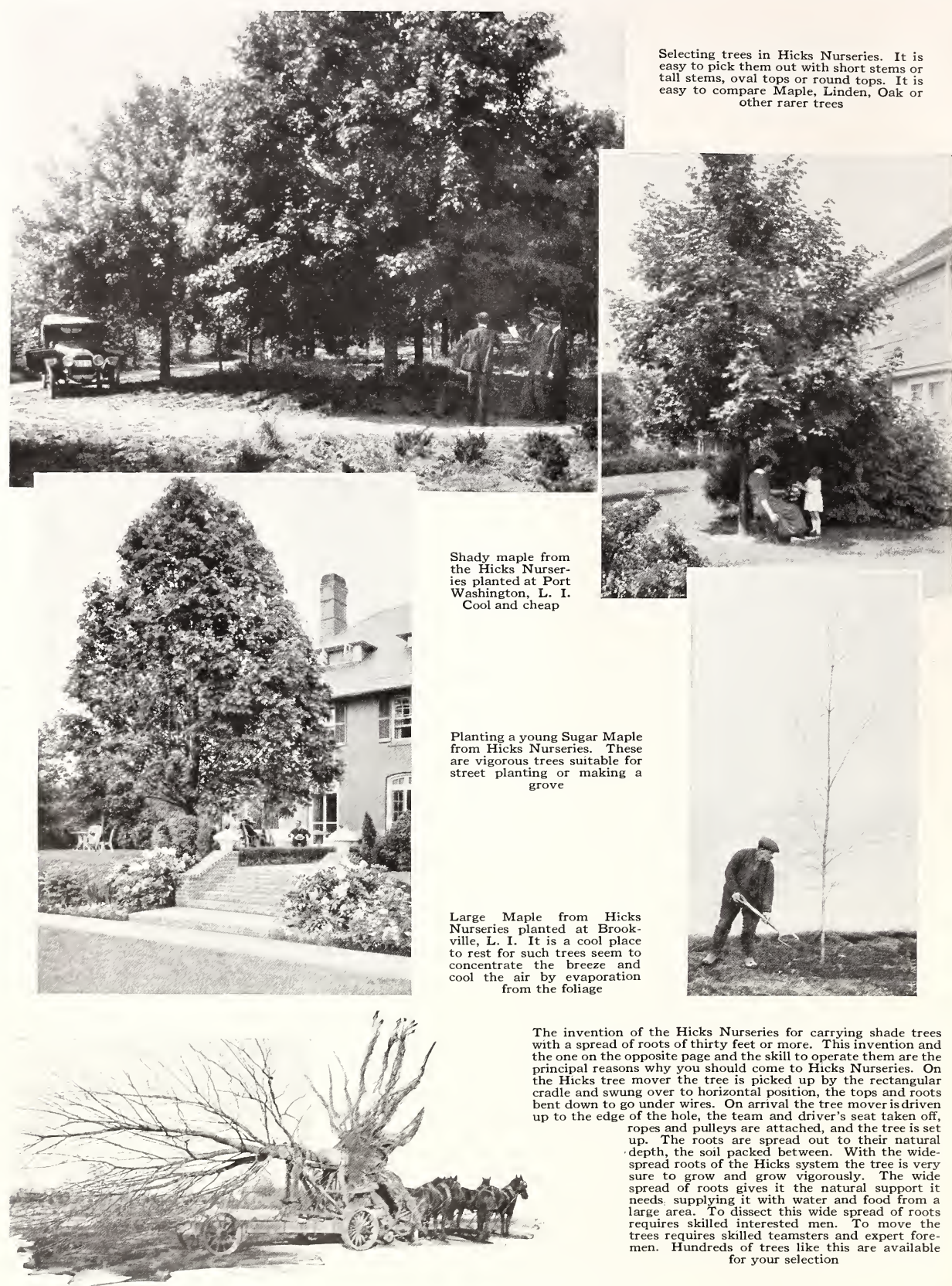

The invention of the Hicks Nurseries for carrying shade trees with a spread of roots of thirty feet or more. This invention and the one on the opposite page and the skill to operate them are the principal reasons why you should come to Hicks Nurseries. On the Hicks tree mover the tree is picked up by the rectangular cradle and swung over to horizontal position, the tops and roots bent down to go under wires. On arrival the tree mover is driven up to the edge of the hole, the team and driver's seat taken off, ropes and pulleys are attached, and the tree is set up. The roots are spread out to their natural depth, the soil packed between. With the widespread roots of the Hicks system the tree is very sure to grow and grow vigorously. The wide spread of roots gives it the natural support it needs supplying it with water and food from a large area. To dissect this wide spread of roots requires skilled interested men. To move the trees requires skilled teamsters and expert foremen. Hundreds of trees like this are available
for your selection 


\section{THE MAPLES}

\section{(Acer)}

HE Maples are a likeable group of trees, cool, comfortable, harmonious. For breadth of shade nothing surpasses them. Hicks Maples are particularly valuable to you because they are broad, and are prepared to economically save you ten, twenty or thirty years. They are guaranteed to grow satisfactorily or replaced free with a new tree loaded at the Nursery.

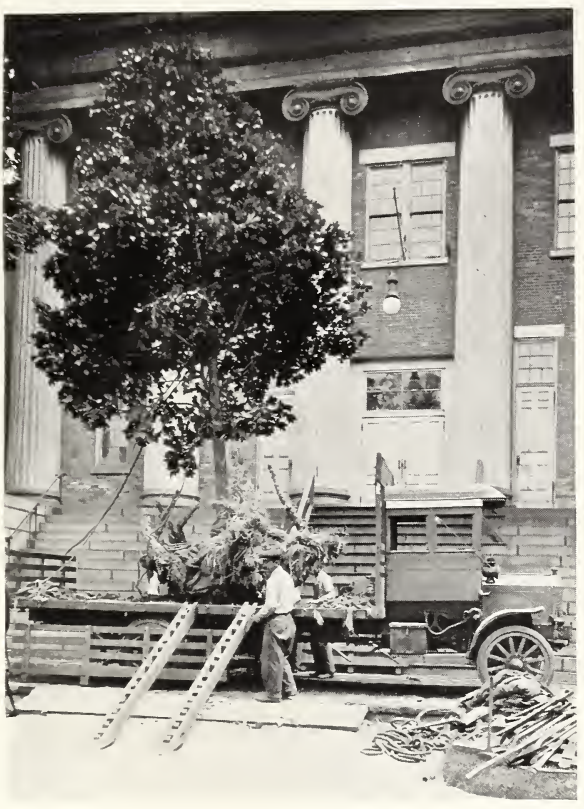

Planting a large Maple in full leaf in mid-summer on a city street. We have recently developed this system of summer planting and recommend it for your trees, because you get shade when you need it most, and the tree is certain to grow better than if moved with bare roots in spring or fall

\section{NORWAY MAPLE, Acer platonoides}

The most serviceable tree of all those that have been planted on Long Island during the past sixty years is the Norway Maple. It's big and shady, no bad habits and no difficulties in transplanting or growing. It seems to like sandy, dry soil, has big, broad, oaklike growth. It's a sturdy, satisfactory all-around good tree.

Where to put one, two or three big Norway Maples is the question now before the house. Some people put it this way, "I want something to take away that bare new look."

The solution is: Come and select, arrange a date of delivery, get a plan of the hole and have the hole dug. Hicks men will plant. Estimates furnished on delivery and planting.

\begin{tabular}{|c|c|c|c|c|}
\hline Height & Age & Diameter & Each & Ten \\
\hline $1 \mathrm{~S}-2$ & & 4 in. & 815. & $\$ 12$ \\
\hline & & $41 / 2$ ir & & \\
\hline & & 5 in. & & 40 \\
\hline & 16 year & & & \\
\hline & & & & \\
\hline & & $8-10 \mathrm{in}$ & & \\
\hline & & & & 1,50 \\
\hline & 25 years & $12-14$ in. & 225.00 & 2,00 \\
\hline
\end{tabular}

\section{RED MAPLE, Acer rubrum}

A broad, oak-like tree with branches just right for a swing. You can pick out trees thirty to forty years old to immediately complete your landscape. In autumn they turn brilliant shades of yellow and crimson.

Carload, barge load and truckload are yours. The time of the year makes little or no difference.

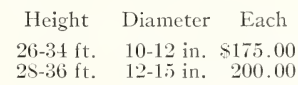

Car load of large trees with roots wrapped in moss and straw. At right. Large shade tree being loaded on freight car. The ball of earth held by canvas and platform is sure to bring the tree to you in good condition
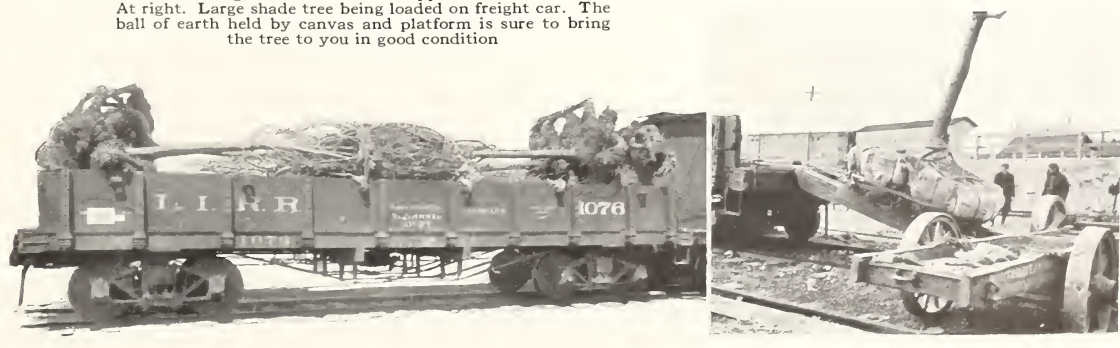


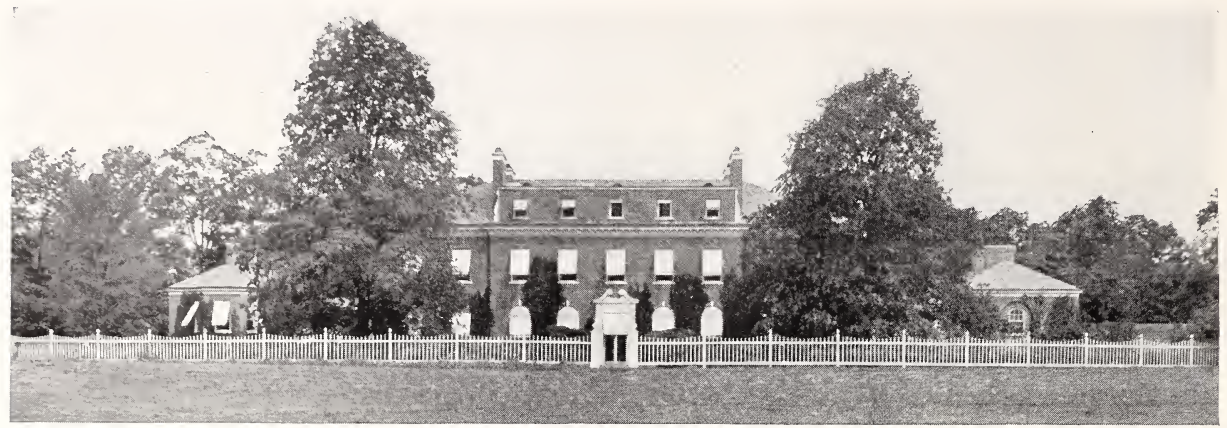

Lindens at the residence of Mr. James A. Burden, Syosset, L. I. Delano and Aldrich, architects. The tree moving department of Hicks Nurseries moved these trees the year before the photograph was taken. The

\section{SUGAR MAPLE, Acer saccharum}

Tall, ovate tree much beloved in northeastern United States for its autumn color and sugar. On Long Island it does well on the heavier soils of the north slope, while the Norway Maple does well on the sandy soils of the south slope. For street and landscape planting we have a quantity of good trees, one and three-quarter inches

achievement of moving such large trees with perfect success is worthy of your investigation. See page 79 for the description of the work of this

\begin{tabular}{|c|c|c|c|c|c|}
\hline \\
\hline Height & Age & Diameter & Each & Ten & Hundred \\
\hline $\begin{array}{l}10-12 \mathrm{ft} . \\
12-14 \mathrm{ft} .\end{array}$ & 10 years & $\begin{array}{r}1 / 2 \\
2\end{array}$ & $\begin{array}{r}\$ 2.50 \\
6.00\end{array}$ & $\$ 22.50$ & $\$ 200.00$ \\
\hline $16-20 \mathrm{ft}$. & & $\begin{array}{c}2-2 \\
3\end{array}$ in. & $\begin{array}{r}0.00 \\
18.00\end{array}$ & & \\
\hline $18-20 \mathrm{ft}$. & & 4 in. & 40.00 & & \\
\hline $22-26 \mathrm{ft}$ & & in. & 75.00 & & \\
\hline $24-28 \mathrm{ft}$. & 16 years & $6-7$ & 95.00 & & \\
\hline
\end{tabular}
diameter.

\section{THE LINDENS}

\section{(Tilia)}

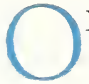

NE of the achievements of the Hicks Nurseries that you will be proud to utilize. When you studied drawing the ellipse was emphasized as a line of beauty. The older books of landscape gardening mention two types of landscape-(I) the beautiful, characterized by the smooth outlines of luxuriant peace and plenty and, (2) the picturesque, showing struggleirregular, wind-torn branches and rocky cliffs. The well-fed and contented outlines of lindens may just complete the picture of your smooth lawn and happy home.

Our enthusiasm for Silver Lindens is based on the condition of two trees at the gateway of Hicks Homestead planted about I880. They have never failed to keep perfect foliage, holding it green for three weeks or more after other trees have turned. You cannot go wrong. Select one or a group of these Lindens for grove, avenue or entrance court. They are prepared to move readily with big balls of earth in full leaf. Therefore the first hot day in June cannot make you feel there is no relief, that you must move to the mountains; you can select a shady grove.

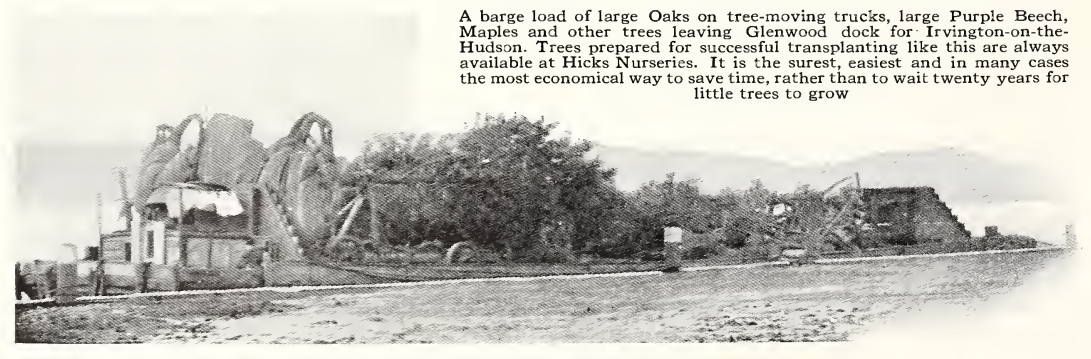




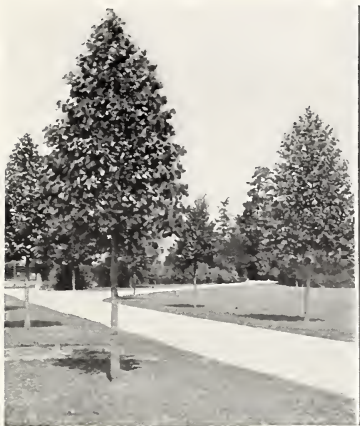

Avenue of Silver Lindens leading to the stable on the Straight, Wheatly, L. I.

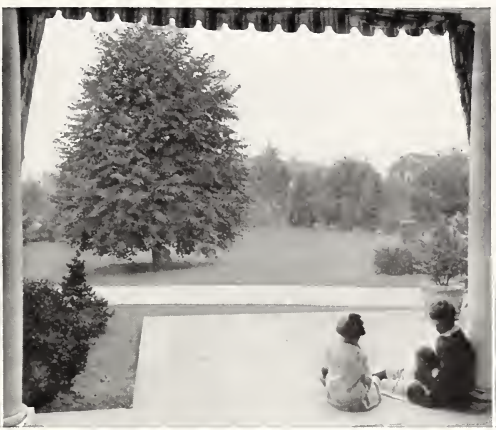

Small-leaved Linden from the Hicks Nurseries on a lawn at Plandome, L, I. The branches come to the ground like a tent making a delightful playhouse

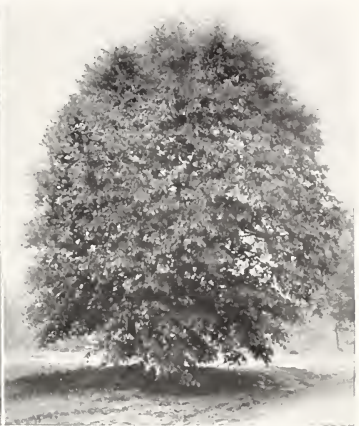

Small-leaved Linden in the Hicks Nurseries waiting to decorate your country place or shade a public park

\section{SMALL LEAVED LINDEN, Tilia cordata}

A great green haystack in shape. The children will delight to play house in the tentlike shade of these Lindens. Their foliage differs from that of the Silver Linden; it is not silver on the under side of the leaves, and the tree is slightly broader. For street planting, low branched specimens to shut off the street and individual specimens, we have a large quantity of excellent trees in the sizes offered.

\begin{tabular}{|c|c|c|c|c|}
\hline Height & Age & Diameter & Each & Ten \\
\hline $12-14 \mathrm{ft}$. & & $21 / 2$ in. & 8.00 & $\$ 70.00$ \\
\hline $14-1$ & & & 18.00 & 160.00 \\
\hline $14-16 \mathrm{ft}$ & & $31 / 2$ in. & 25.00 & 225.00 \\
\hline $14-16 \mathrm{ft}$ & & 4 in. & 40.00 & 350.00 \\
\hline $16-20 \mathrm{ft}$. & & in. & 60.00 & \\
\hline $1 \mathrm{~S}-24 \mathrm{ft}$ & & in. & 75.00 & \\
\hline $18-2+\mathrm{ft}$ & & in. & 125.00 & \\
\hline $20-26$ & year & in. & 140.00 & \\
\hline
\end{tabular}

\section{SILVER LINDEN, Tilia tomentosa}

\begin{tabular}{|c|c|c|c|c|}
\hline Height & Age & Diameter & Each & Ten \\
\hline$-22 \mathrm{f}$ & & $5 \mathrm{in}$. & $\$ 50.00$ & $\$ 450.00$ \\
\hline & & 6 in. & 75.00 & 700.00 \\
\hline $26 \mathrm{ft}$. & & 7 in. & 100.00 & 900.00 \\
\hline $28 \mathrm{ft}$. & & 8 in. & 150.00 & \\
\hline$-30 \mathrm{f}$ & & $10 \mathrm{in.}$ & 180.00 & \\
\hline $3-30 \mathrm{f}$ & years & $11 \mathrm{in.}$ & 200.00 & \\
\hline
\end{tabular}

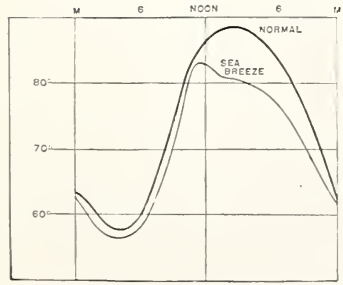

Diagram showing normal daily curve on a hot summer day, and the effect produced by the sea breeze
The best and coolest place for the children can be at for the children can be at
home under a grove of Hicks shade trees. The diagram is from Elementary Physical GeoElementary Physical Geography by R. S. Tarr. During the day the land tends to flow toward the tends to flow toward the warm areas from the cool sea, thus producing a very refreshing sea breeze. You can enjoy the effect planting Hicks Shade can romp and play under their cooling shade. In the hot summer days enjoy your Linden trees of a cool breeze at home by
Below. Pleached alley of Small-leaved Linden on the estate of Mr. Thomas Hastings, Westbury, L. I.

Why are some gardens and terraces hot and unattractive? There is no shaded walk from which to enjoy them
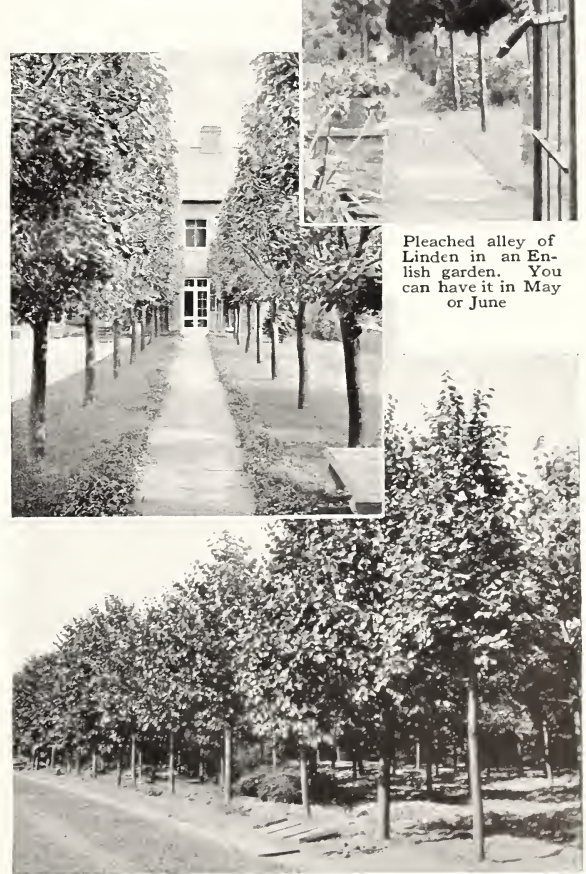

Silver Lindens ready to make pleached alleys, avenues, grovesor specimens. Architects have advised us how they want them. We have marked a circle on the ground, and made an elliptical wire on a pole as a guide for trimming 

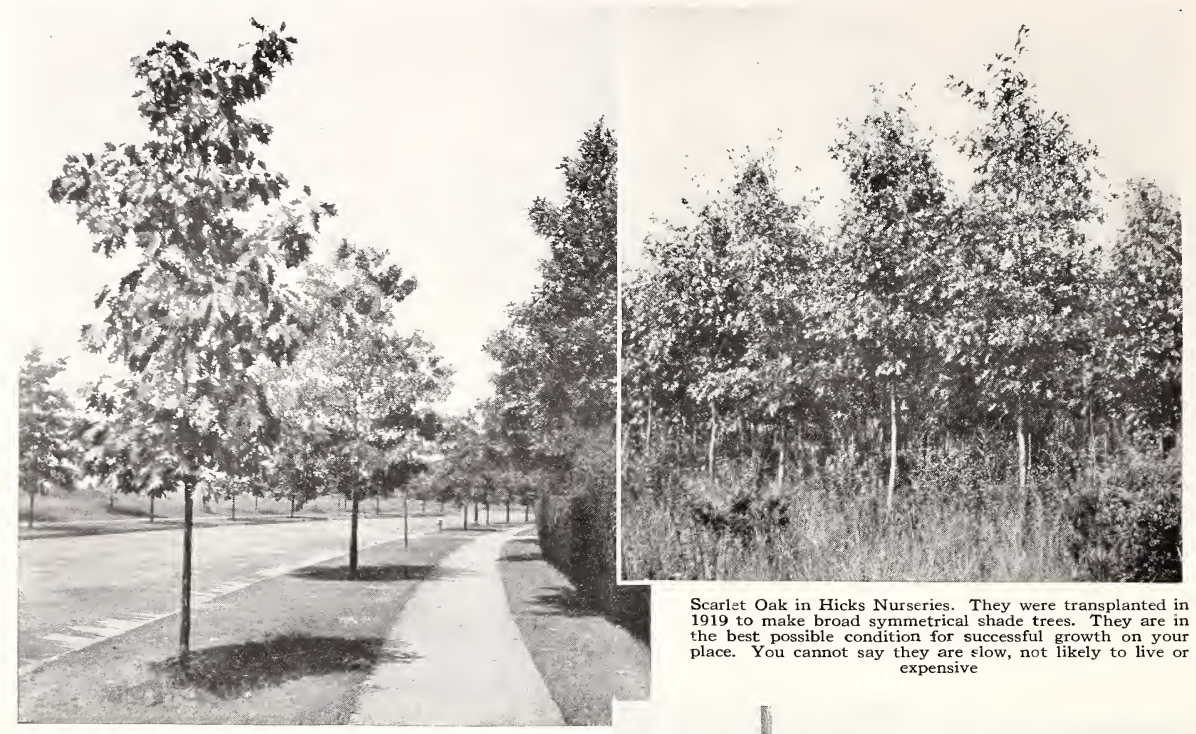

Scarlet Oak in Hicks Nurseries. They were transplanted in 1919 to make broad symmetrical shade trees. They are in the best possible condition for successful growth on your
place. You cannot say they are slow, not likely to live or expensive

Avenue of Oaks in Garden City, photographed September, 1923 when rain fall was less than half normal and many trees were sad, yellow and drooping their leaves

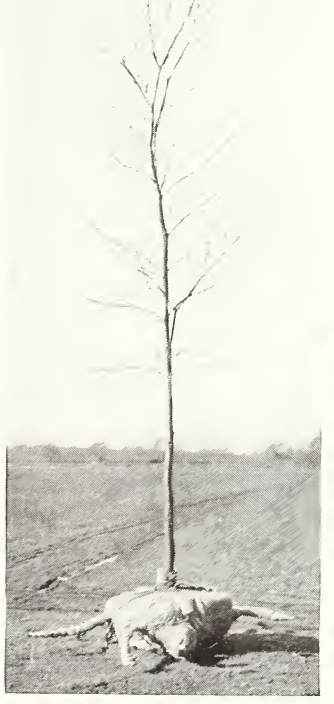

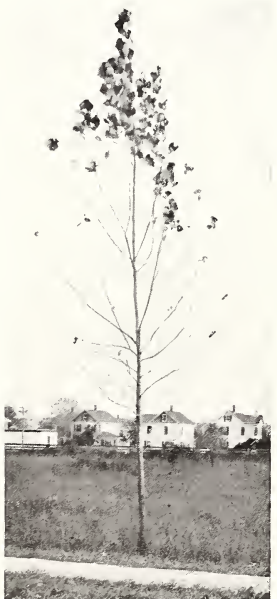

Above. Poplar tree suffering for lack of water. Such trees are soon broken by borers and people
wonder why the landscape is sad Left. Chestnut Oak with ball of earth and roots extending from ball. This is a new method we have invented for moving trees formerly considere
cult to make live

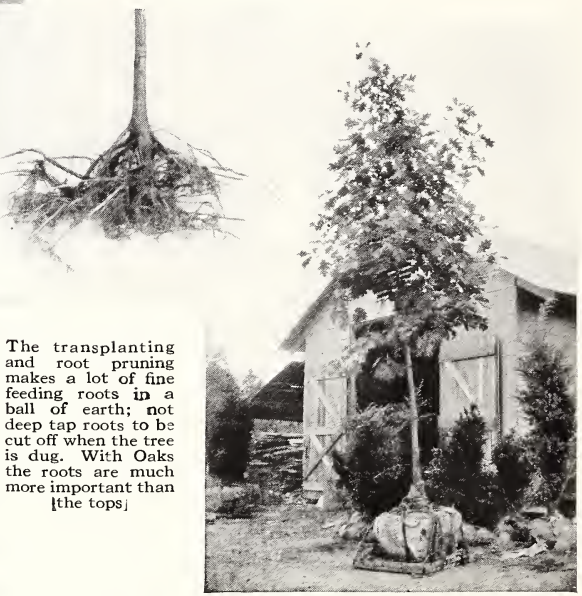

Red Oak with ball of earth held by canvas and platform invented by the Hicks Nurseries. By this system you are assured of the best trees moved in the best way, resulting in the best landscape

SUMMER PLANTING

As you will notice this tree is being delivere in full leaf You can have eighty per cent in full leaf. more of the different kinds of trees and shrubs planted all summer with as good or better results than in ther with a bette summer and have a larger growth next year summer and have a larger growth next year We developed summer planting for evergreens and discovered it is best for Oak Beech, Tulip, Hornbeam and many difficult species. Summer planting pays. Why? 


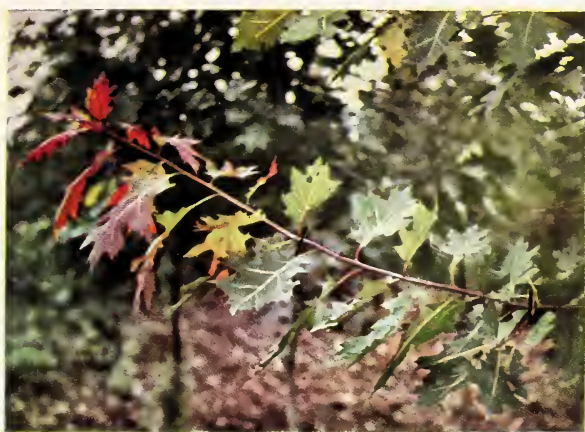

Oaks often make two growths each season. Lower part of this branch grew in June, the upper part in July and August. Maples do not grow

\section{THE OAKS \\ (Quercus )}

P ERHAPS you haven't planted Oaks because they were not offered, or because they were liable to die after being transplanted, or because you thought they were slow-and they were slow when transplanted and cared for in the ordinary way.

We have overcome ninety per cent of these difficulties.

Oaks were not offered because it is difficult to get the acorns. Some years there are none, other years the worms spoil them or the nurserymen are too busy to pick them up. Sometimes mice or chipmunks get them where they are stored or planted. We have a goodly number and variety coming along all the time.

Oaks often died when dug and planted in the ordinary way, with the roots chopped short and the tops left long. Oaks do not put forth a lot of new roots early in the season like some other trees. If the small fibrous roots are broken off or cut off in digging, the top must be cut back very severely and the tree freely watered in dry weather until new roots have had time to grow.

Our stock, carefully transplanted, root-pruned and dug, has more of fibrous rootlets and is guaranteed to live.

Not all Oaks are slow of growth. Our Scarlet Oaks will show an annual growth of two and occasionally three feet. You can't show better growth on Lindens, Maples, or even Planes and Poplars planted in similar soil. Like the "hare and the tortoise" the latter may shoot ahead for the first few years, but the Oaks will catch up with them later on.

Plant Oaks. They are beautiful both in form and color of foliage. Some hold their leaves all winter. They thrive on soils too poor and sandy for many other trees. They stand up against ocean blast and prairie wind, and laugh in time of drought when other trees are feeble and unhappy.

You have the land and money, we have the trees-let's swap.

Large Red Oak leaving the Hicks Nurseries for Mr. R. Waverley Smith, Red Spring, Glen Cove, L. I. With trees like this why plant Poplars where they will be sick in half a dozen years?

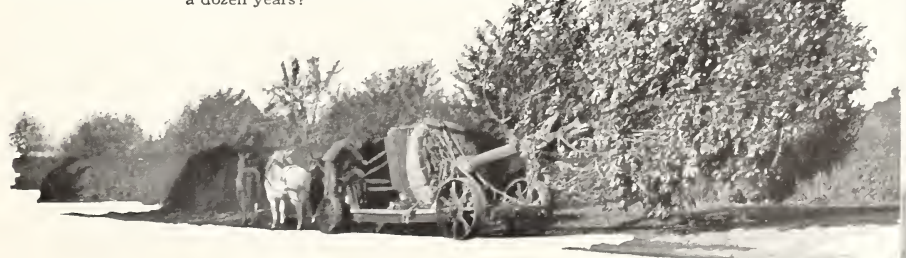




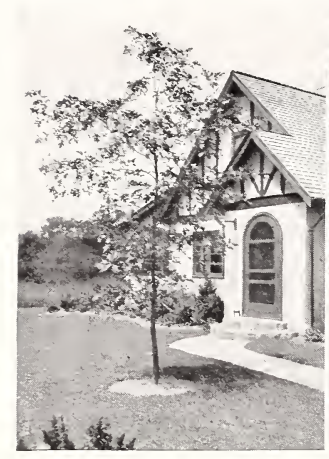

Scarlet Oak planted at

Port Washington, L. I

These small trees are economical and give a wide shade because they are grown wide apart

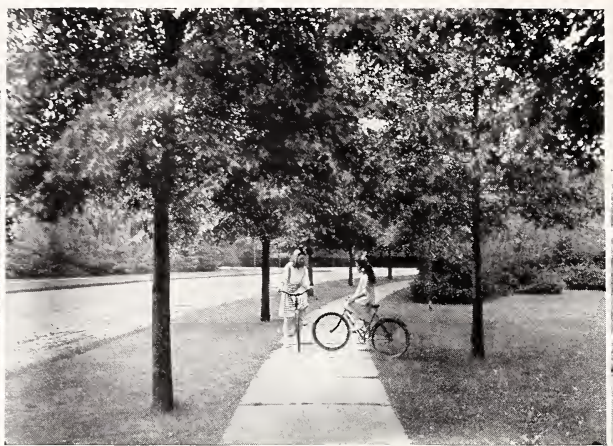

Avenue of Oaks at Nassau Boulevard, Garden City, L. I With good trees like this on the street you need less trees on your land. The Oaks make the best background for your home landscape of lawn, shrubs and flowers

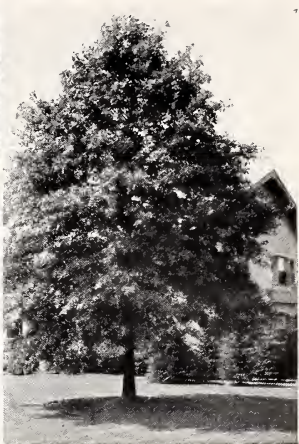

Large Pin Oak from the Hicks Nurseries planted for Mr. J. D. Dann larger than this are ready for you

\section{SCARLET OAK, Quercus coccinea}

Your eye has been trained to the beauty of autumn foliage, but perhaps not to notice and classify the various species of trees that glorify the landscape at this time of year.

It is safe to say that from Long Island southward the greatest amount of brilliance, and the most enduring, is furnished by the Scarlet Oak. It is the predominant bright red species on the hills and plains of Long Island and New Jersey. It is red from mid-autumn until mid-winter or later. The red-russet color remains even until the leaves are pushed off the following spring.

The Scarlet Oak is a noble forest tree of large dimensions, drought-resisting, adapted to sand and gravel, suitable for street trees, boundary plantations, groves, orwith pines and other oaks - for ocean windbreaks.

Its foliage is held throughout the winter, the leaves seeming to hang on longest where the soil is dryest.

\begin{tabular}{|c|c|c|c|c|}
\hline Height & Age & Diameter & Each & Ten \\
\hline $5-6 \mathrm{ft}$. & & & $\$ 2.00$ & $\begin{array}{r}\$ 17.50 \\
35.00\end{array}$ \\
\hline $\begin{array}{l}8 \mathrm{ft} . \\
10 \mathrm{ft} .\end{array}$ & & $1^{1} \cdot 2$ in. & $\begin{array}{l}4.00 \\
6.00\end{array}$ & $\begin{array}{l}30.00 \\
50.00\end{array}$ \\
\hline $12-14 \mathrm{ft}$. & 10 years & $2 \mathrm{in}$ & 12.00 & 100.00 \\
\hline $14-16 \mathrm{ft}$. & & $2^{1 / 2}$ in. & 18.00 & 150.00 \\
\hline
\end{tabular}

\section{SUMMER PLANTING}

With these root pruned Scarlet Oaks with balls of earth, you can plant in summer. Then they are sure to grow and need no cutting back to a narrow top requiring three years to catch up again.

\section{RED OAK, Quercus rubra}

The Red Oak is native on Long Island at Freeport, on the hills round Lake Success and along the north shore above the outcrop of springs on the deep fjords like Hempstead Harbor and at Locust Valley.

People admire the Red Oak with its clean smooth bark, wide gravity defying branches, leaves as big as your hand and acorns as big as your thumb.

You will enjoy picking out one of our Red Oaks that fits into your landscape - with high branches to let the breeze under, or old and spreading like a pasture tree, with limbs strong enough for swing or hammock. No tree is better for the children's playground. For your Oak hunger there are Red Oaks in various sizes up to the thirty-two year old tree on page $2 \mathrm{I}$.

$\begin{array}{lcrc}\text { Height } & \text { Diameter } & \text { Each } & \text { Ten } \\ 10-14 \mathrm{ft} . & 2 \text { in. } & \$ 12.00 & \$ 100.00 \\ 14-16 \mathrm{ft} . & 21 / 2 \text { in. } & 18.00 & 150.00\end{array}$
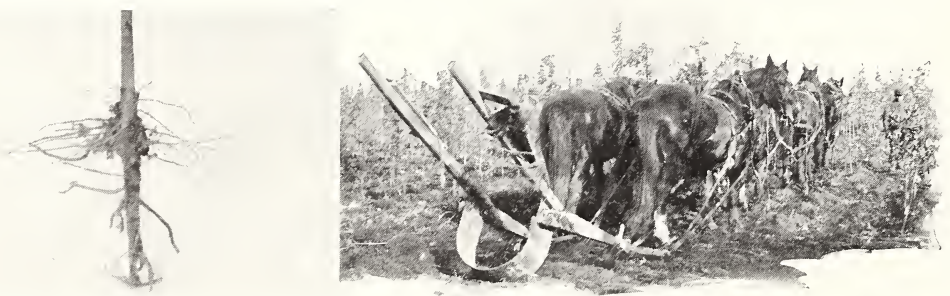

U - blade root pruner with eight horses, to cut the tap roots of young make them like the roots illustrated on page 20

The normal Oak root, with a long tap root like a 


\section{CHESTNUT OAK, Quercus prinus}

Here's a dry ground species you may not know, rapid of growth, and which you will be proud to introduce to your friends. It grows on the gravel of Rockaway and Bayville beaches, on High Hill (the highest hill of Long Island) and on the dry shoulders of Cold Spring Harbor. Some of the trees have horizontal branches reaching out for forty feet, like the old Oaks in English parks as north of Piping Rock in the field east of the school.

Plant Chestnut Oaks along the street, they will grow almost as rapidly as the Oriental Plane and are much hardier. If you want lawn specimens consider the Chestnut Oak, especially if you have a sandy or gravely soil.

$\begin{array}{rllrr}\text { Height } & \text { Age } & \text { Diameter } & \text { Each } & \text { Ten } \\ 12 \mathrm{ft} . & & 2 \text { in. } & \$ 12.00 & \$ 100.00 \\ 14-16 \mathrm{ft} . & 10 \text { years } & 2^{1 / 2} \text { in. } & 18.00 & 150.00 \\ 14 \mathrm{ft} . & & 3 \text { in. } & 35.00 & \\ 1 .-22 \mathrm{ft} . & & 4 \text { in. } & 50.00 & \end{array}$

\section{PIN OAK, Quercus palustris}

A big, fast growing tree. When young it has the grace and symmetry of the Linden, a broad, oval tree. When old it has the rugged strength and wide spreading branches of the other Oaks. You have an opportunity to develop your Oak enthusiasm without extravagance, without risk. There are hundreds of trees available for your selection, fifteen, twenty and fifty years old.

One year seedlings six inches high you can buy for planting with Pines and shrubs for boundary, game cover, bird sanctuary or hill-side.

\begin{tabular}{|c|c|c|c|c|}
\hline Height & Age & Diameter & Each & Ten \\
\hline $\begin{array}{l}-20 \mathrm{ft} . \\
0-26 \mathrm{ft} \\
6-2 \mathrm{ft}\end{array}$ & 20 yrs. & $\begin{array}{lll}4^{1 / 2} & \text { in. } \\
5 & \text { in. } \\
6 & \text { in. } \\
7 & \text { in. } \\
8-9 & \text { in. }\end{array}$ & $\begin{array}{r}\$ 35.00 \\
60.00 \\
100.00 \\
125.00 \\
150.00\end{array}$ & $\$ 300.00$ \\
\hline
\end{tabular}

\section{Shade This Summer}

The Scarlet Oak picture on the right shows what you get in a Pin Oak for $\$ 75.00$. There are hundreds to select from. May, June, July and August are when you need shade, when you can best pick them out and when you can have them delivered, planted and guaranteed.

\section{WHITE OAK, Quercus alba}

The noblest tree of eastern America. We have twentyyear old trees and younger. They are among the slower growing Oaks, but when you get them of this age, you have no excuse not to plant what you know to be the best.

$\begin{array}{ccccc}\text { Height } & \text { Age } & \text { Diameter } & \text { Each } & \text { Ten } \\ 12 \mathrm{ft} . & & 21 / 2 \mathrm{in.} & \$ 20.00 & \$ 18.5 .00 \\ 14 \mathrm{ft} . & 15 \text { years } & 3-4 \mathrm{in.} & 35.00 & 325.00\end{array}$

Close-up front view of U-blade root pruner. This sharp blade cuts off the deep tap root and long side roots. From every cut end a cluster of several small feeding roots grows out again. Without root pruning the single roots reach on and on for many feet, and it is impractical or difficult to save them when digging the tree

\section{BLACK OAK, Quercus velutina}

One of the most widely spread Oaks on Long Island on the hills, among the Pitch Pines, borders of the plains and seashore. Surveyors frequently put down Black and Scarlet Oak as Red Oak. When established it will prove a fast growing, dignified tree. It has red foliage in the autumn similar to the Scarlet Oak. We call them Elm and Poplar substitutes for Garden City.

\begin{tabular}{|c|c|c|c|}
\hline Height & Age & Diameter & Each \\
\hline $\begin{array}{r}10 \mathrm{ft} . \\
12-1+\mathrm{ft} .\end{array}$ & & & $\begin{array}{r}\$ 10.00 \\
18.00\end{array}$ \\
\hline $16-1 \mathrm{~s} \mathrm{ft}$. & & $31 \frac{2}{2}$ in. & 35.00 \\
\hline
\end{tabular}

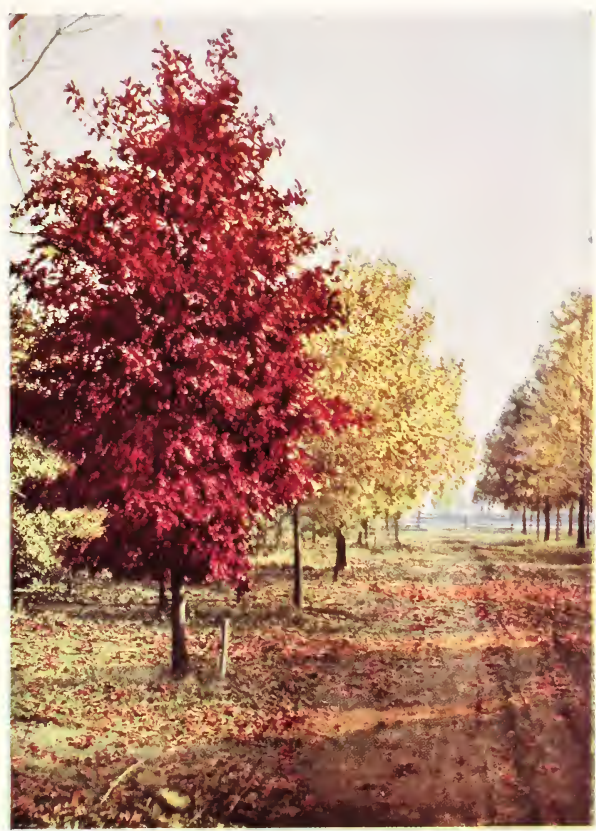

Color photograph taken in the Hicks Nurseries; in the foreground Scarlet Oak, in the background Norway Maple, changing color in the autumn. There are miles of roads like this. You are welcome to explore at any time to pick out trees that fit your needs

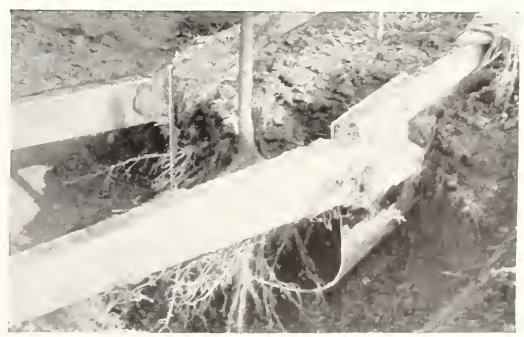




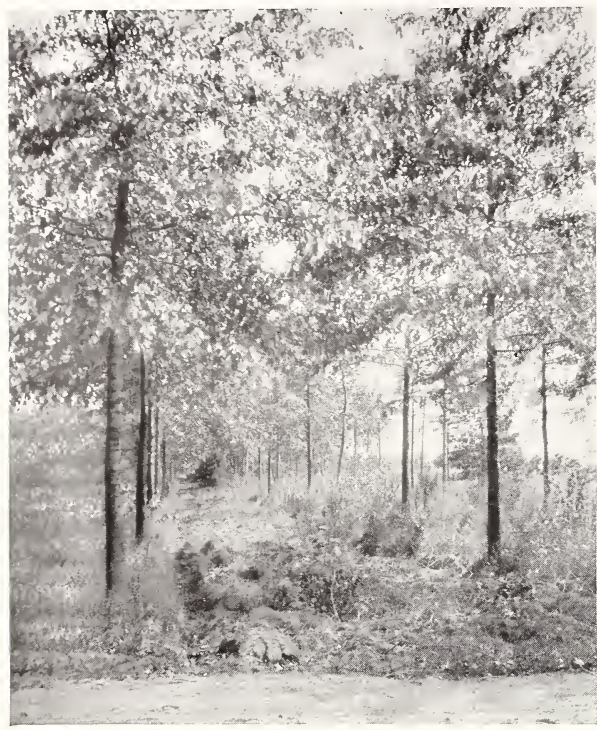

Double row of Pin Oaks in the Hicks Nurseries planted so as to train them to arch a path. With big broad trees like this and larger there know they are best and if you do not plant the best, your mistake is evident now and for a century or more

\section{SHINGLE OAK, Quercus imbricaria}

William Cullen Bryant had an arboretum at Roslyn. We gathered the seed from one of these about twenty years ago, now they are ready for you, big, broad specimens. The habit of the tree is like the Pin Oak. The leaves show no notches like other oaks, but are shaped like a laurel leaf.

\begin{tabular}{ccr} 
Height & Diameter & \multicolumn{1}{c}{ Each } \\
$14-18 \mathrm{ft}$. & 3 in. & $\$ 35.00$ \\
$16-20 \mathrm{ft}$. & $4-5$ in. & 45.00
\end{tabular}

\section{SWAMP OAK, Swamp White Oak, Quercus bicolor}

Tree similar to the White Oak, but quicker. Native on Long Island at Flushing, Glen Head and Westbury on hard pan or clay soils. Big, broad, dignified trees that save your time. Carloads ready for Detroit, St. Louis, Toledo, Kansas City, Louisvi!le, Cleveland and Chicago.

$$
\begin{aligned}
& \text { Height Age Diameter Each Ten } \\
& 16 \mathrm{ft} . \quad 4 \text { in. } \$ 40.00 \$ 375.00 \\
& \text { 18-22 ft. } 16 \text { years } 5 \text { in. } \quad 50.00 \quad 475.00
\end{aligned}
$$

Post Oak, Blackjack Oak, Scrub Oak and Dwarf Chinquapin Oak are happy and beautiful on the dryest and poorest soils. Come and see how they can make your place beautiful, how you can lower the up-keep of your place.

\section{THE BEECH}

\section{(Fagus)}

TF you are a connoisseur of trees, you will sympathize with the landscape architect who looked over our stock and said: "Some day I am going to plant a grove of Beeches!" or with the other who said: "I did not know such fine Beeches were available."

You have seen Beeches in the woods, perhaps have carved your initials-and your sweetheart'son their smooth, gray bark. But have you noticed their ability to be happy under and between other trees? They do not struggle upward with tall bare trunks, but keep their lower branches, arching them downward and outward to the light, beautiful, graceful and strong. They are quietly beautiful all the year.
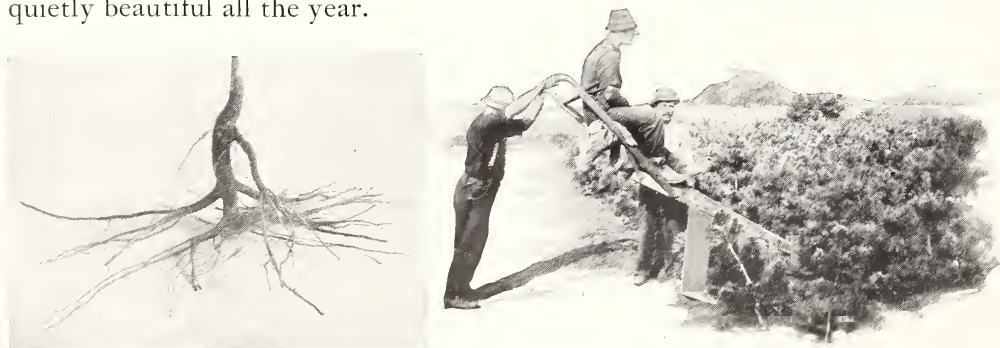

L-blade root pruner. Starting blade at the end of a row of White Pine trees, it cuts the $t$ a p root and the side roots on one side. used on the other side

Oak tree root three years after root pruning. Instead of the tap root going down three to seven feet it branches out sideways. The side roots instead of continuing on as long pipe lines have branched into small feeding roots 


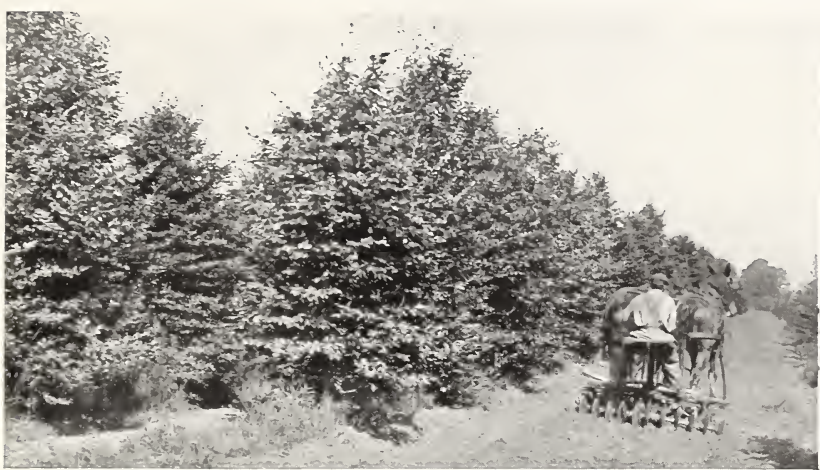

Block of Beeches moved February, 1919. They are just right for a hedge, screen of low branched trees or for specimens. Hornbeams are almost identical and, you can get pleached alleys $20 \mathrm{ft}$. high

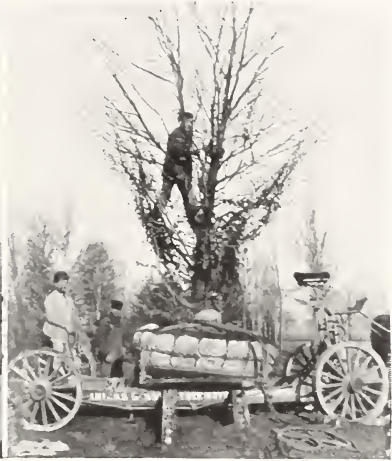

The Hicks way of moving Beeches and other difficult trees makes them sure to

Do you want a hedge that is different, that is better? Consider these Beeches. They will keep their foliage right to the ground, whether you let them grow naturally, clip them to a wall like a vertical line at the sides, or-better-to a sloping line, wider at the bottom. You can keep them small by reaching in and taking out the longest branches.

A good way to use them is as a belt or grove of low-branched trees to bound your landscape or shut out the street. They keep some straw-colored leaves all winter, and may be considered in some degree as an all-year screen.

Taken up with a ball of earth, the Beech may be planted any time. You will see signs in the nursery "This block of Beeches moved Summer, I92 I," “This block of Beeches moved JanuaryFebruary, I920." Make your own selections from these blocks-you will be getting the best in preparation, root growth, tops, and methods of digging and delivery. Pick out the ones suited to your own needs; some are fat and squatty as an old Dogwood, others reach upward like a Poplar; some have tall smooth trunks, but most of them are branched to the ground.

AMERICAN BEECH, Fagus americana

\begin{tabular}{|c|c|c|c|}
\hline Height & Age & Each & Ten \\
\hline $3 \mathrm{ft}$. & & $\$ 4.00$ & $\$ 35.00$ \\
\hline $4 \mathrm{ft}$. & & 5.00 & 45.00 \\
\hline $5 \mathrm{ft}$. & & 8.00 & 75.00 \\
\hline $6 \mathrm{ft}$. & & 10.00 & 85.00 \\
\hline $12 \mathrm{ft}$. & & 40.00 & 350.00 \\
\hline $14 \mathrm{ft}$. & 18 years & 50.00 & 450.00 \\
\hline
\end{tabular}

EUROPEAN BEECH, Fagus sylvatica

\begin{tabular}{|c|c|c|c|}
\hline Height & Age & Each & Ten \\
\hline $3-4 \mathrm{ft}$ & & $\$ 3.00$ & $\$ 27.50$ \\
\hline & & 5.00 & 45.00 \\
\hline & & 10.00 & 85.00 \\
\hline 12 & & 35.00 & 300.00 \\
\hline $14 \mathrm{f}$ & 18 years & 50.00 & 450.00 \\
\hline
\end{tabular}

PURPLE BEECH, Fagus sylvatica purpurea

Deep, red purple foliage in May, changing to dark, purplish green in late summer.

$\begin{array}{rrrr}\text { Height } & \text { Ten } & \text { Height } & \text { Ten } \\ 1-5 \mathrm{ft} . & \$ 10.00 & 8-10 \mathrm{ft} . & \$ 30.00 \\ 5-6 \mathrm{ft} . & 18.00 & 10-12 \mathrm{ft} . & 40.00\end{array}$
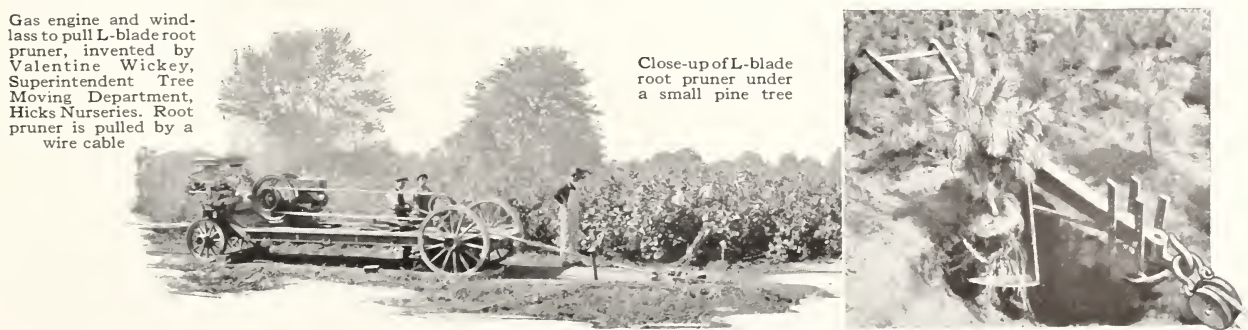


\section{THE SWEET GUM}

\section{(Liquidambar)}

T F you do not know the Sweet Gum, permit us to introduce it. Plant a Sweet Gum on the street in front of your place, or put one on your lawn; you and your grandchildren will be proud of it. If you have a grove or belt of trees and there are no Sweet Gums, find a place for one, even if you have to take out a more ordinary tree. If you need an extensive mass planting or street planting at low cost, we have small sized Sweet Gums, one and a quarter inches in diameter and ten feet tall, just right for these uses.

The Sweet Gum can be the crowning glory of your landscape in Autumn. It turns early, and no tree is more varied in coloring, ranging as it does from lemon-yellow through orange, scarlet and crimson to purple-red.

\begin{tabular}{|c|c|c|c|c|}
\hline Height & Age & Diameter & Each & Ten \\
\hline $10-12 \mathrm{ft}$. & & $1 \frac{1 / 2}{\text { in. }}$ & $\$ 3.50$ & $\$ 30.00$ \\
\hline $12-14 \mathrm{ft}$. & & $2-3$ in. & 15.00 & 100.00 \\
\hline $14-18 \mathrm{ft}$. & & $3-4$ in. & 40.00 & 350.00 \\
\hline $14-18 \mathrm{ft}$. & 17 years & $4-5$ in. & 60.00 & \\
\hline $16-18 \mathrm{ft}$. & & $5-6$ in. & 75.00 & \\
\hline
\end{tabular}

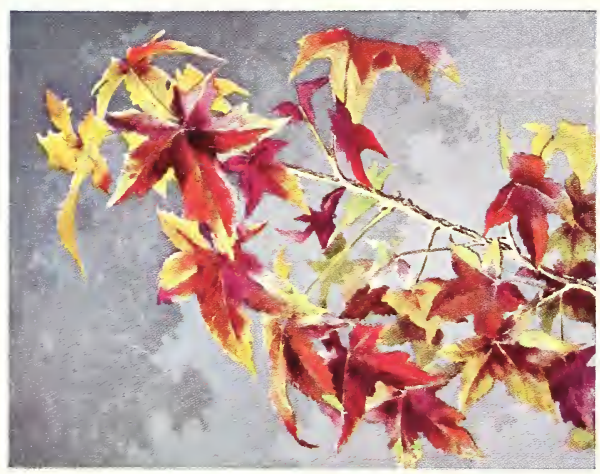

Sweet Gum in early autumn. No printing can show the glory of sun shine through the foliage

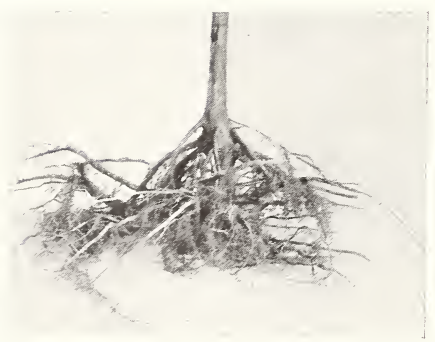

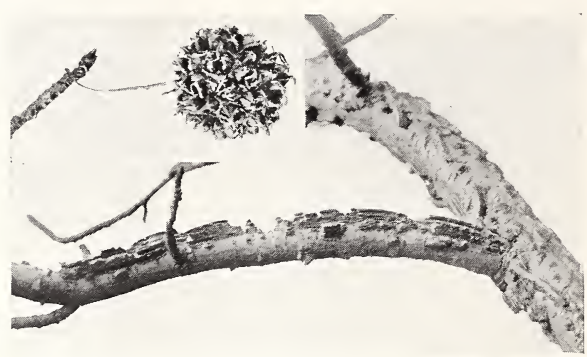

Know the Sweet Gum by the seed ball and the corky ridges on the bark which give you something interesting in the winter

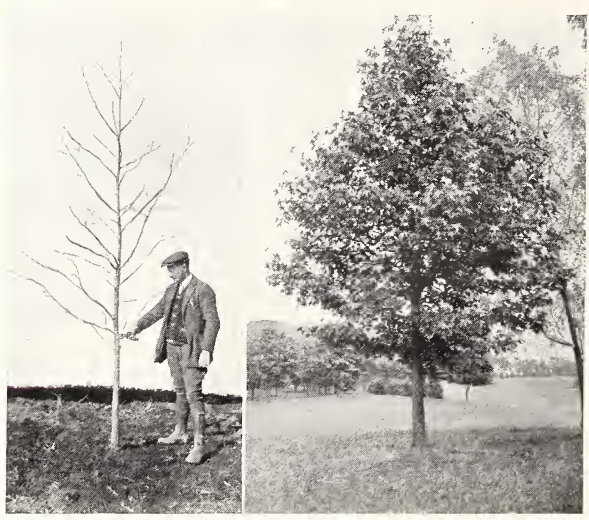

The quality of Sweet Gum you can buy at the Hicks Nurseries at low prices
Sweet Gum on the lawn of Mr. Charles Steele, Westbury, L. I.

Root of Oak tree after three times root pruning. Compare this with the long carrot-like tap root on page 22 . When this tree is dug, with or
without a ball of earth, there are enough small feeding roots to supply food and water to the tree

(A) On the opposite page are shown the roots of a tree that have not been root pruned, and the small amount of feeding roots on such a tree. A gardener in Cleveland, Ohio, said of this kind of tree, "I would not have them. They set out a little tree and leave it alone for seven years, and it don't have roots enough to live. Your trees, Mr. Hicks, have the right kind of roots." (B) The same kind of a Spruce tree that has been repeatedly root pruned with U-blade. (C) Shows portion of root as indicated. (D) A cross section of this root pruned tree to compare with $\mathrm{A}$ 


\section{THE DOGWOOD}

\section{(Cornus )}

M

ANY know the Dogwood and have seen the signs, "Spare the Dogwood. It takes years for a branch to grow," in an effort of the Garden Club to prevent breaking by autoists.

You can have the beauty of the Dogwood on your own place, however small, back it up with Pines, and underplant with Laurel and Azalea.

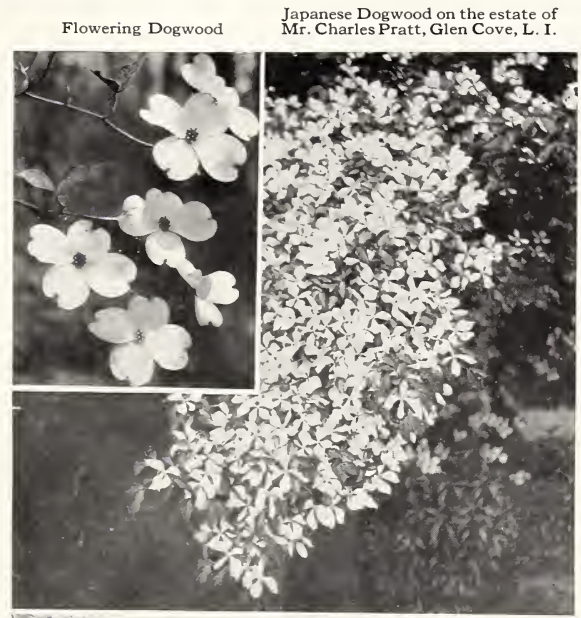

The strata of white which its blooms produce on the edges of the forest and in the forest have made people love it. You can safely use Dogwood in your shrubbery to raise up the sky outline, but more especially to underplant Oak, Pine, Tulip, Liquidambar, and other trees, for it delights in a partly shaded position and does not like to stand alone in a dry, windy situation.

Plant ten, fifty, one hundred, five hundred. Try it to border your woodland drives, bridle paths and walks. Play the game according to the rules. Do what nature would do but do it first. Our Dogwoods are available any time of the summer.

WHITE FLOWERING DOGWOOD, Cornus florida

$\begin{array}{rrr}\text { Height } & \text { Each } & \text { Ten } \\ 5 \mathrm{ft} . & \$ 4.00 & 837.50 \\ 6 \mathrm{ft} . & 6.00 & 55.00 \\ 8 \mathrm{ft} . & 8.00 & 75.00 \\ 10 \mathrm{ft} . & 10.00 & 90.00\end{array}$

RED FLOWERING DOGWOOD, Cornus florida rubra $2-3$ ft. $\$ 5.00$ each

\section{JAPANESE DOGWOOD, Cornus kousa}

Like our Dogwood except that it is a month later. Plant it in your woods, groves and shrubbery.

$$
\begin{array}{rrc}
\text { Height } & \text { Each } & \text { Ten } \\
3-5 \mathrm{ft} . & \$ 3.00 & \$ 27.50 \\
5-\mathrm{fft} . & 6.00 & 55.00
\end{array}
$$

Dogwood on the estate of Mrs. J. Rodgers Maxwell, Red Spring, Glen Cove, L. I. Trees of this size are available
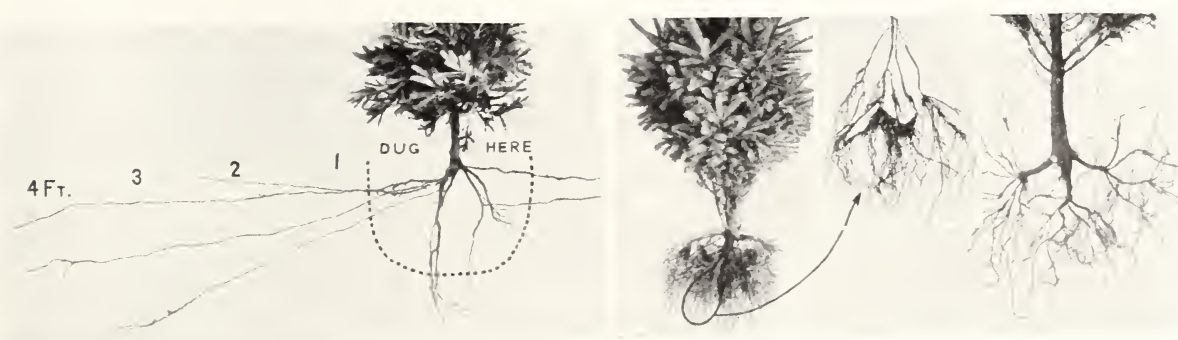


\section{TULIP TREE \\ (Liriodendron Tulipifera)}

TALL, ovate tree native on the northern slope of Long Island and at Wantagh on the southern slope. Flowers appear in June and resemble large yellow tulips, shaded with green. You will admire the tree on street, lawn, or in the forest, for its straight trunk is as graceful as a Grecian column. Because they are difficult to transplant, we take them up with big balls of earth, like an evergreen, any time of the year.

$\begin{array}{cc}\text { Height } & \text { Each } \\ 16 \mathrm{ft} . & \$ 30.00 \\ 18 \mathrm{ft} . & 45.00\end{array}$

\section{GOLDEN RAIN TREE, Koelreuteria paniculata}

A Chinese tree with panicles of lemon yellow flowers in July when flowers are scarce. These panicles are a foot long making a showy little tree to add to your boundary.

$$
\begin{array}{ll}
\text { Height } & \text { Each } \\
4-6 \mathrm{ft} . & \$ 4.00 \\
6-8 \mathrm{ft} . & \$ .00
\end{array}
$$

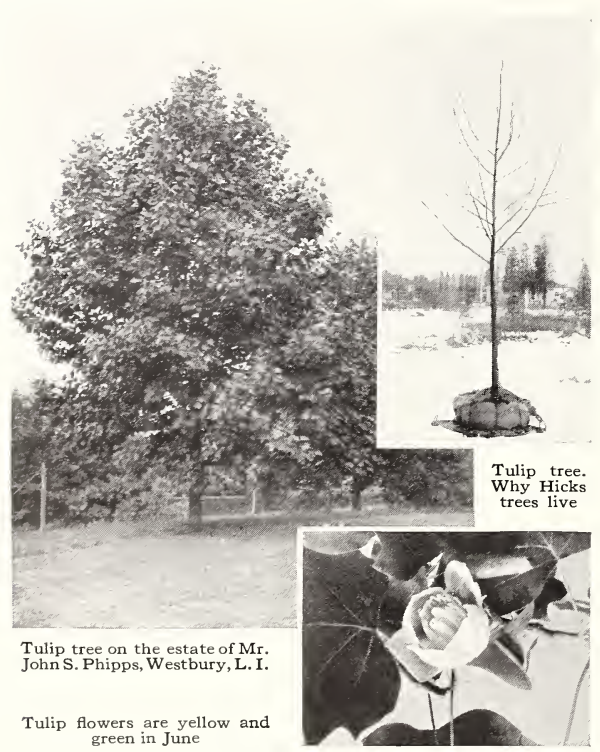

WHY HICKS TREES ARE THE BEST TO PLANT

Digging a shade tree in Hicks Nurseries. They don't start close up to the tree and hack off the roots. The Hicks operators take delight in saving the small feeding roots. They start out near the ends of the roots, dig a trench below the roots, undermine the bank, then they pick out the soil with a slender iron picking rod or with a digging fork. The soil falls to the bottom and is shoveled out, as is shown by. the man on the left. The roots are carefully lifted up by the hands, gatheredin bundies, tied with string and bent up toward the trunk of the tree, as shown in the center and on the right. When this operation has continued to within three or four feet of the center, the roots are wrapped with damp material, as shown on pages 15 and 20. The ball of earth is undermined, wrapped and loaded on a platform, as shown on page 17. These methods are safe to transplant the trees in full leaf so when you want shade you can get it the next week. Another method is to continue to dissect out the roots and load the tree as shown on page 16

\section{PEPPERIDGE, Nyssa sylvatica}

In the swamps and on the hillsides, the horizontal branches of this tree make it easily recognized by tree overs. The small, oval leaves turn as early as the Liquidbefore the Scarlet Oak. Use them as small trees in your shrubbery, in groves of Pines, Liquidambars and Oaks.

$\begin{array}{lrr}\text { Height } & \text { Each } & \text { Ten } \\ 2-3 \mathrm{ft} . & \$ 3.00 & \$ 27.50 \\ 6-8 \mathrm{ft} . & 6.00 & 50.00\end{array}$

SILVER BELL, Halesia tetraptera

Beautiful little tree hung with snow drops in early May. Use them for the high points in the shrubs or low points of the tree grove.

$$
\begin{array}{cr}
\text { Height } & \text { Each } \\
3 \mathrm{ft} . & \$ 2.50
\end{array}
$$

\section{OTHER TREES}

In addition to the trees described in this catalogue there plied only in small sizes, but even so any plant enthusiast will be well repaid by them. varieties, and Hornbeams we want you to make a personal are especially adapted for formal gardens while the Maidenhair or Ginkgo and Japanese Walnut should be given plenty of room on the lawn. If you have in mind any tree not listed in our catalogue, write us about them.

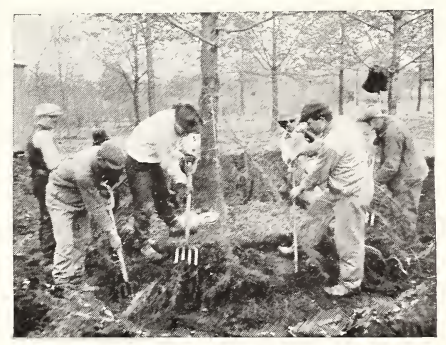




\section{Section II EVERGREENS}

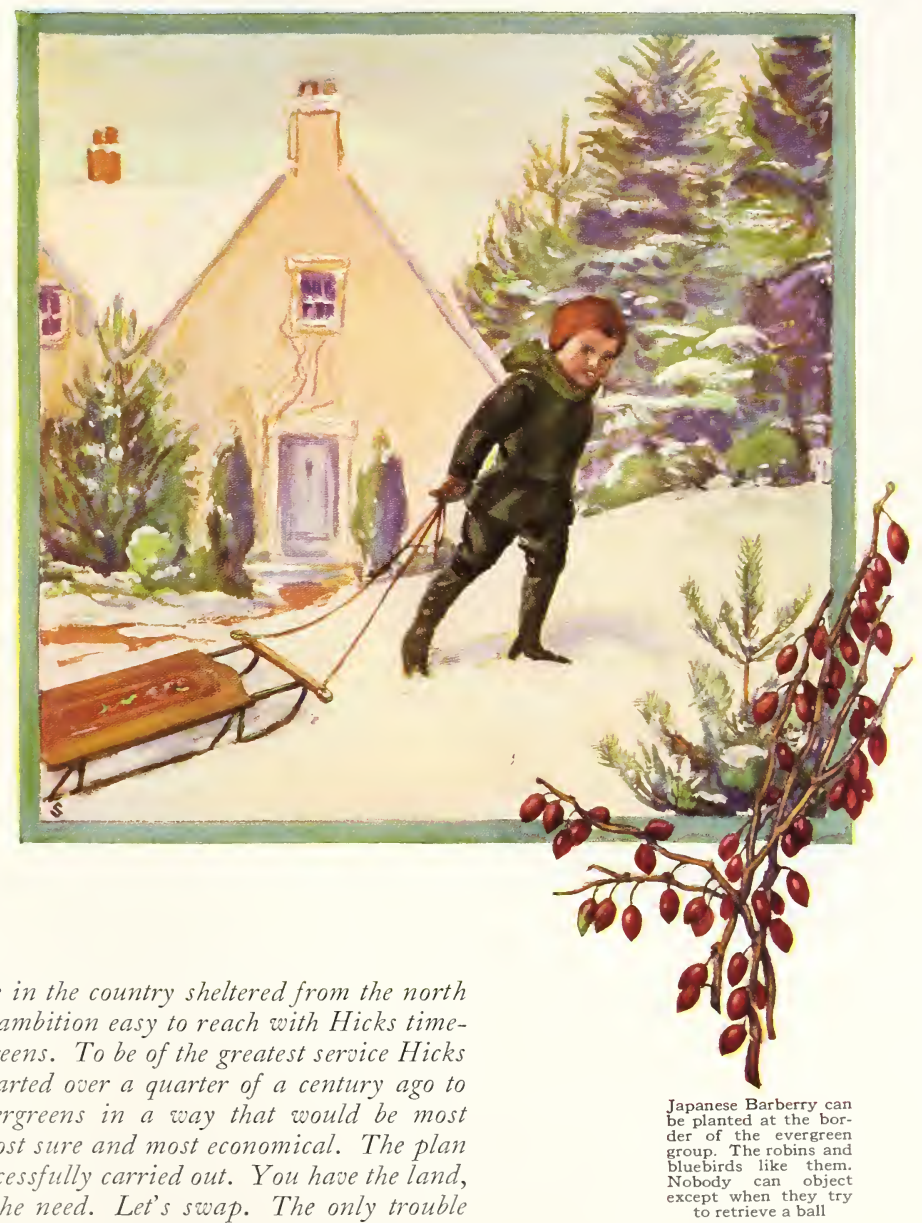

$A$ little place in the country sheltered from the north winds is an ambition easy to reach with Hicks timesaving evergreens. To be of the greatest service Hicks Nurseries started over a quarter of a century ago to grow big evergreens in a way that would be most beautiful, most sure and most economical. The plan has been successfully carried out. You have the land, the money, the need. Let's swap. The only trouble with the picture is that the artist has put the trees too near the house, and the Pine at the corner should have been cut back every Fune. 

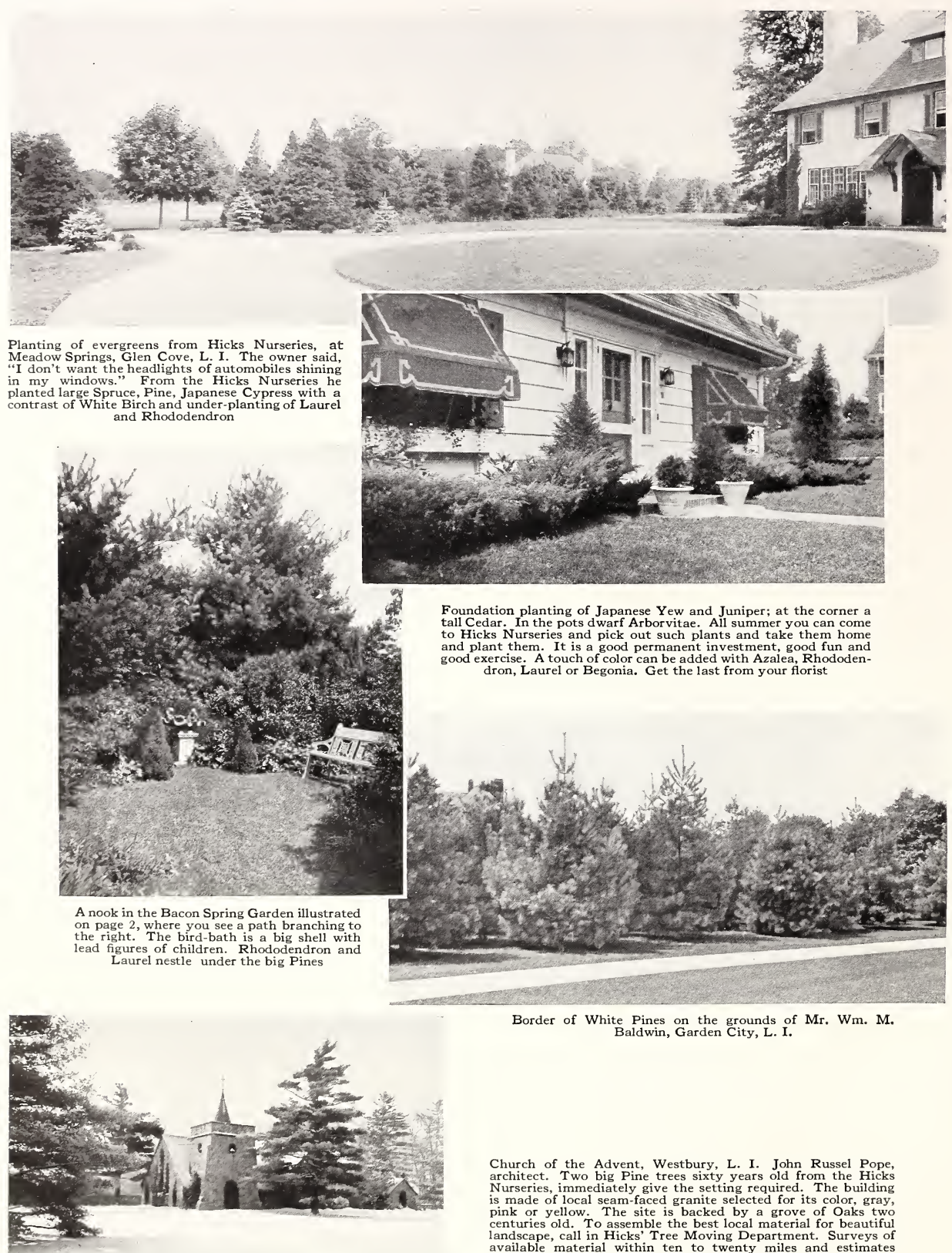

Border of White Pines on the grounds of Mr. Wm. M. Baldwin, Garden City, L. I.

Church of the Advent, Westbury, L. I. John Russel Pope, architect. Two big Pine trees sixty years old from the Hicks Nurseries, immediately give the setting required. The building is made of local seam-faced granite selected for its color, gray, pink or yellow. The site is backed by a grove of Oaks two centuries old. To assemble the best local material for beautiful landscape, call in Hicks' Tree Moving Department. Surveys of available material within ten to twenty miles and estimates on what is best worth moving are economically supplied 


\section{THE ALL-YEAR LANDSCAPE}

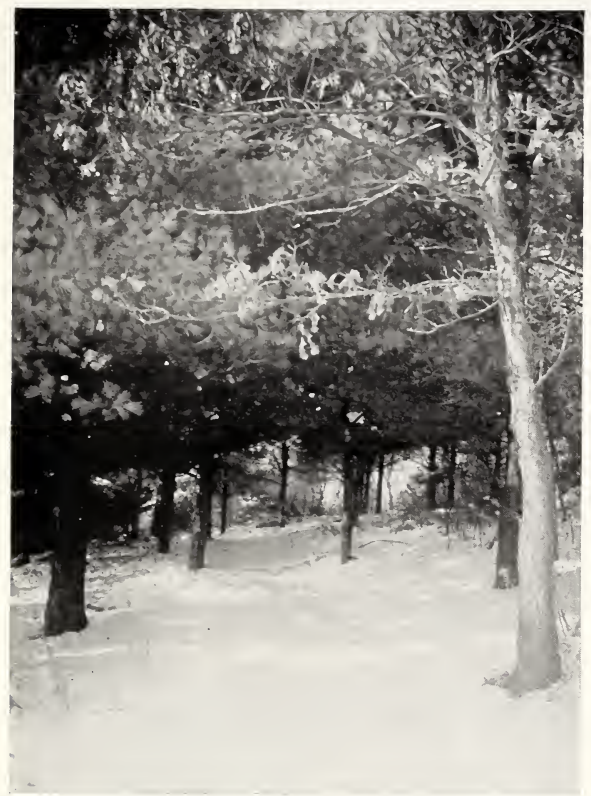

Pine forest planted in 1893 for Mr. Edwin D. Morgan, Wheatley, L. I. Now they are twelve inches in diameter, big enough to build a house. You can carry out the Roosevelt-Pinchot-Sargent idea by protecting
and planting forests like this. On the right a White Oak shows the best partnership
COU need evergreens for service, comfort, privacy, beauty and all-the-year enjoyment of nature. Frank J. Scott, author of "The Art of Beautifying Suburban Home Grounds," says, "Some of the most prized pictures of great landscape painters are scenes that lie close to the eye, which derive their beauty from breadth of view, or variety of objects, and yet they may be marvels of lovely or picturesque beauty."

With walls of evergreens or evergreens and the Winterleaf-holding Oaks, Hornbeams and Beeches, you can create these beautiful pictures to be enjoyed all winter.

Men like evergreens, women like flowers; evergreens are the best background for fiowers. Children like the grove of their Christmas trees.

Long Island is an all-the-year residence region. Evergreens like the sandy soil of Long Island. Hicks Nurseries have for seventy years experimented with the evergreens of the northern hemisphere (those of the southern are not hardy) and now have ready for you thousands that keep the highest beauty. They have developed methods of root pruning, transplanting and delivering with large balls of earth to make them highly successful and economical.

Dwarf Evergreens. Here is a new hobby-ride it hard or easy. You had best come and pick them out. You will find here low spreading carpets, flat domes and picturesque miniature trees of low stature that will reward your hike through Hicks Nurseries.

Bring us new evergreens, we will introduce and name them for you. There is need of dwarf Pitch Pine, short-leaved Yellow Pine, Red Pine, Jack Pine, Jersey Pine, Table Mountain Pine, Hemlock and Red Cedar. S. A. Everett, treasurer of Doubleday Page and Company, found a Golden Hemlock.

Redecorating Your Place. Rip out some old shrubs in the border like Privet, Deutzia or Spirea, and put in Pine, Hemlock and Holly. It takes courage. It is not as easy as redecorating walls. It is easier than getting rid of old and friendly furniture.

Oaks and Pines border the Bacon estate at Westbury. This view is at the entrance to the house of Mr. George Whitney shown in the airplane view on page three. When this was planted in 1912, the late Ambassador Robert Bacon said, "Mr. Hicks, I cannot make my farm pay growing alfalfa. I'd like to plant trees. I have been told I should buy the next farm across the road, but you can keep on doing that indefinitely. We should plant it out." I said, "The best way to do is as Mr. J. F. D. Lanier did on the estate now owned by Mr. Charles Steele. He planted little trees." "Yes, I went by there the other day. I thought that looked right," I said, "The trouble with planting little trees is that people have to be old enough planting little trees is that people have to be old enough little trees." Mr. Bacon looked at Mrs. Bacon, smiled and said, "It was about then, wasn't it?"

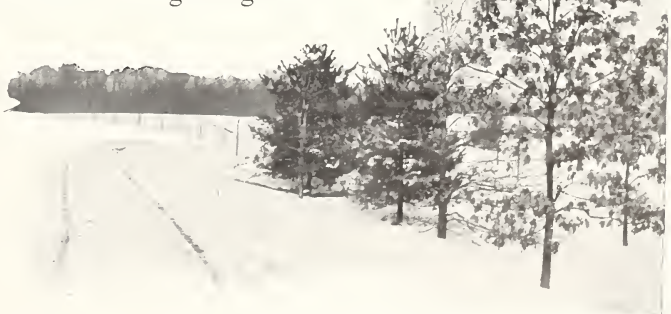




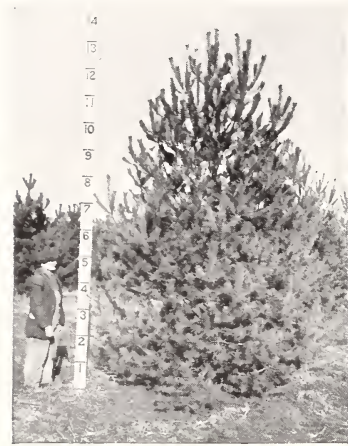
Scotch Pine. These will
give you the most cubic
yards of dense foliage for
the least money. (There
are hundreds like this for you to choose from)

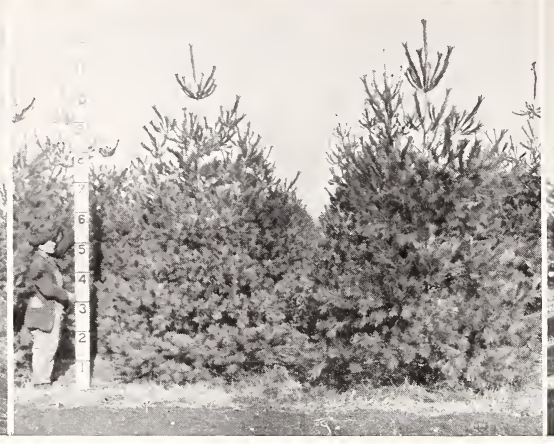

White Pine twelve to fourteen feet high. There were hundreds of them selected when they were last transplanted in 1920 because they did not have long bare necks. The branches grow upward making dense solid screens

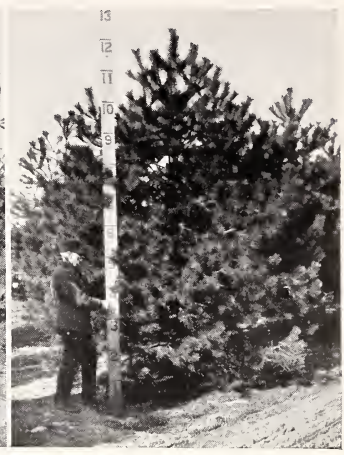

Austrian Pine thirteen feet high. A car load of these has gone to Pittsburgh this spring. Smoke, salt and wind do not affect them

\section{THE PINES}

\section{(Pinus)}

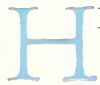

ICKS NURSERIES specialize on Pines because Pines specialize on Long Island. They like dry, sandy soils, exposed wind swept shores and mountain sides. Most other evergreens prefer swamp and ravine.

Pines are not freely offered in nurseries because to get their food from gravelly, sandy and rocky soils they have long coarse roots. The founder of Hicks Nurseries said when Pines were six feet high, "We will cut down these Pines and mulch the strawberry bed." It was not then considered practical to transplant them larger. Now it is done by the invention, skill, foresight and investment of Hicks Nurseries.

Our invention of canvas and platform system is one part of it, but not all. Previous training of the tree, knowledge of the requirements of the tree applied while digging, and after care are essential if you are to get the best results for your investment in land, time and money.

Joseph Wickey, veteran tree mover, shifts the Pines in the nursery like checkers. Therefore when you get them they hold their own. They do not get thin, yellow and doubtful. You can look right back on the annual growths and see that each year is a

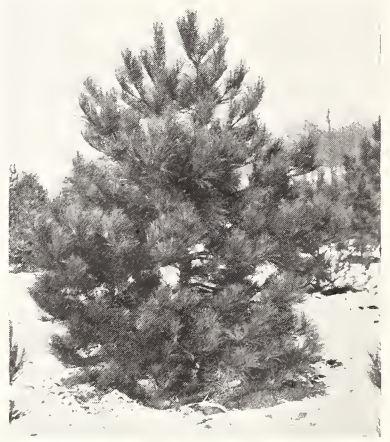

Red Pine, the most beautiful velvety dark green foliage. These were moved in 1922 and are in the best possible condition to give you big value
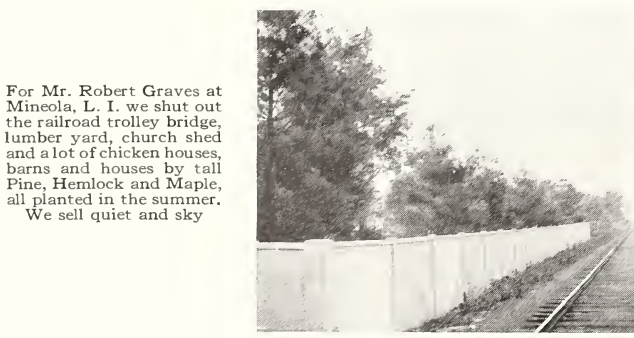

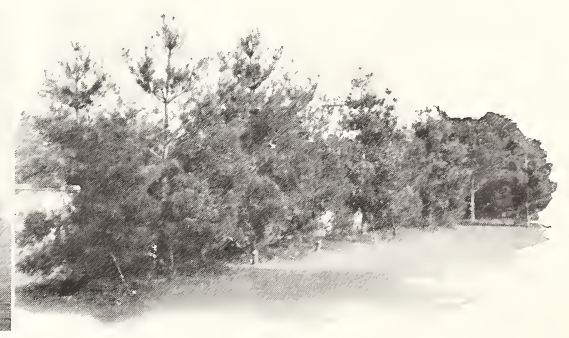




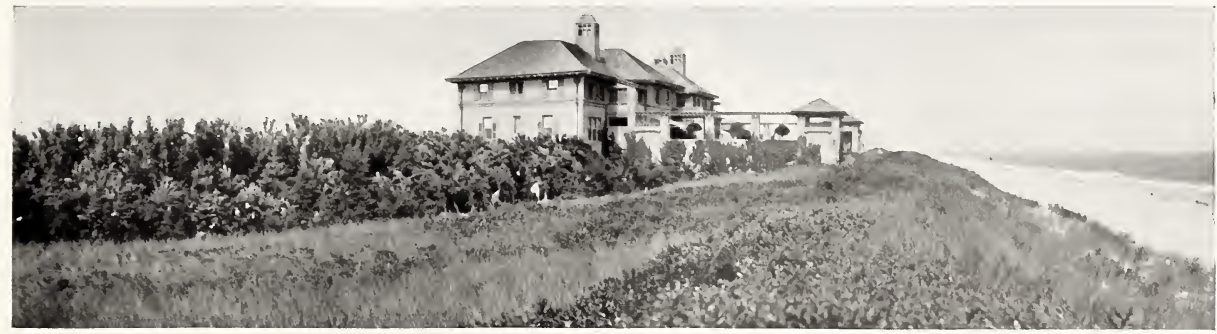

Eight carloads of salt spray resistant Pines from Hicks Nurseries planted here in August to screen an outdoor gymnasium. For trees to stand the severe conditions of the seashore they must learn from the sand dunes. The sand establishes an equilibrium between surf and wind

The trees must slope at the same angle, so that the wind slides over the inclined top of the forest. The salt kills the tops of the first tree, but the second tree can be a few inches higher

nearly full normal growth even the year when it says they were moved, as "This Block of Pines moved January, I9I9" or "This Block of Pines moved, February, I920."

These trees are now standardized. You can order a carload, truck load or barge load from the catalogue with guarantee of satisfactory growth.

You can come to the nursery as did a young couple from Garden City who inaugurated the practice. They would spend holidays going through the nursery, picking out specimens. When the young man was complimented on his ability to pick perfect trees, he said: "I am in the machine tool business and when a thing is I Ioooth of an inch out it is wrong.'

We will show you in June how to keep your Pines down to the job. You want them twelve feet high to shut out the street and the first and second story of adjacent houses and not the sky. Cut them back one-quarter, one-half or three-quarters of the present year's growth, then perhaps ten, not five, buds will form, resulting in a dense, fluffy growth next year. Let the base be broader than the top. Let the sun shine on the bottom limbs or as the lower limbs die off, do as in the forest, plant an undergrowth of other evergreens. Don't expect them always to retain their juvenile lower branches. That is contrary to nature and good landscape. Under the best designed landscapes there is an undergrowth of ferns, shrubs, young trees.

\section{WHITE PINE, Pinus strobus}

The noblest evergreen of eastern America.

The trees six feet high are just right to shut out the street. They will grow one foot in June and one and onehalf feet next year; they are immediate and economical. The trees twelve feet high are just right for a hedge or irregular boundary planting. They could not be better and they are worth the price to you now and in their certainty of future beauty. We will show you some here over eighty years old. They are native in many parts of Long Island. If you are on the Hempstead Plains see how perfectly they grow in our nursery. You can plant them all summer and all winter the same as you can most other trees in this catalog.
Outdoor gymnasium and tennis court screened by tall trees. It is easier
to play when the ball shows against a green background

Your home grounds give the most pleasure when they are divided by pleasure when they are divided by for different uses

\begin{tabular}{rrrr} 
Height & \multicolumn{1}{c}{ Each } & Ten & Hundred \\
$2 \mathrm{ft}$. & $\$ 2.00$ & $\$ 17.00$ & \\
$4 \mathrm{ft}$. & 6.00 & 55.00 & $\$ 500.00$ \\
$6 \mathrm{ft}$. & 12.00 & 100.00 & 900.00 \\
$8 \mathrm{ft}$. & 18.00 & 150.00 & \\
$10 \mathrm{ft}$. & 30.00 & 250.00 & \\
$12 \mathrm{ft}$. & 40.00 & & \\
$14 \mathrm{ft}$. & 50.00 & & \\
$16 \mathrm{ft}$. & 60.00 & & \\
$18 \mathrm{ft}$. & 90.00 & & \\
$20 \mathrm{ft}$. & 115.00 & & \\
$22 \mathrm{ft}$. & 135.00 & & \\
$24 \mathrm{ft}$. & 150.00 & & \\
$26 \mathrm{ft}$. & 175.00 & &
\end{tabular}

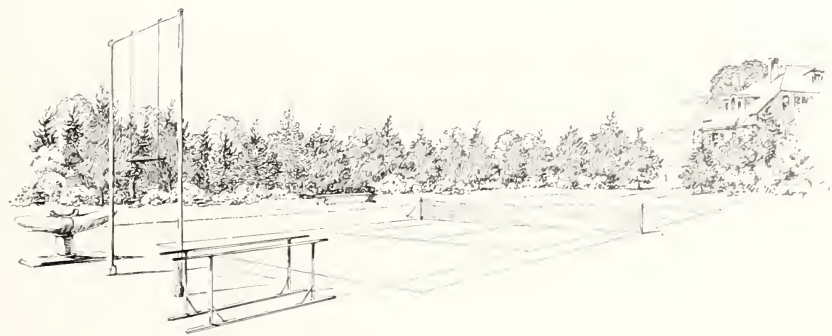




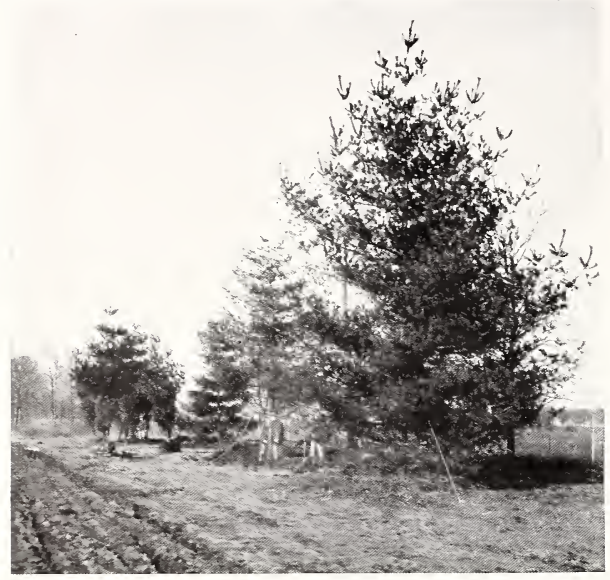

Belmont Park. Planting White Pines. There are many more like these for you at any time as offered on the previous page

\section{RED PINE, Pinus resinosa}

Native from Maine to Minnesota. It is named from its reddish bark. It has deep velvety green soft foliage in long tassels. It is native on the dry sandy plains and thin soil on ledges of rock, therefore it will not be unhappy on the dry soils of Long Island. Use Red Pines for a dividing hedge or windbreak on the north side of your homestead. Plant them among your shrubs, then keep the shrub; cut back so that the Pines will keep their lower foliage. Use them to screen your garage or poultry house. For foundation planting their needles may be a little too long, but for an immediate mass of green on the corner you will not make a serious mistake. Nipping in June will make them dense and symmetrical. Later they can be replaced with something of smaller texture. If good evergreens are your need, don't forget to see our Red Pines. They are in the southwest corner of the nursery.

\begin{tabular}{rrr} 
Height & Each & \multicolumn{1}{c}{ Ten } \\
$1-2 \mathrm{ft}$. & $\$ 2.00$ & $\$ 17.50$ \\
$4-5 \mathrm{ft}$. & $\$ .00$ & 75.00 \\
$5-6 \mathrm{ft}$. & 15.00 & 125.00 \\
$6-\$ \mathrm{ft}$. & 25.00 & 220.00 \\
$8-10 \mathrm{ft}$. & 60.00 & \\
$12 \mathrm{ft}$. & 70.00 &
\end{tabular}

\section{MUGHO PINE, Pinus montana mughus}

Little cushions one foot high and two feet wide. In five years they may be three feet high and six feet wide. Bright green, hardy. Use in sunny, windy places.

$\begin{array}{cccccc}\text { Spread } & \text { Each } & \text { Ten } & \text { Spread } & \text { Each } & \text { Ten } \\ 1 \mathrm{ft} . & \$ 4.00 & \$ 35.00 & 11 / 2 \mathrm{ft} . & \$ 5.00 & \$ 40.00\end{array}$

\section{AUSTRIAN PINE, Pinus nigra (Austriaca)}

Seashore planting cannot omit this salt spray resistant Pine. Are you at Newport, Easthampton, Southampton, Long Beach, Cedarhurst, Woodmere, Far Rockaway, Long Branch, Atlantic City, carloads or truck loads are ready any time of the year.

\begin{tabular}{|c|c|c|}
\hline Height & Each & Ten \\
\hline $2 \mathrm{ft}$. & $\$ 5.00$ & $\$ 40.00$ \\
\hline $3 \mathrm{ft}$. & 6.00 & 70.00 \\
\hline $6-8 \mathrm{ft}$. & 35.00 & 300.00 \\
\hline $8-10 \mathrm{ft}$. & 50.00 & 450.00 \\
\hline $10-12 \mathrm{ft}$. & 65.00 & 600.00 \\
\hline $16 \mathrm{ft}$ & 100.00 & 900.00 \\
\hline
\end{tabular}

\section{KOREAN PINES, Pinus koraiensis}

A blue green tree of compact growth and long graceful foliage. It is related to the White Pine and has large edible nuts.

$\begin{array}{crc}\text { Height } & \text { Each } & \text { Ten } \\ 1-2 \mathrm{ft} . & \$ 3.00 & \$ 25.00 \\ 2-3 \mathrm{ft} . & 5.00 & 40.00 \\ 3-4 \mathrm{ft} . & 7.00 & 60.00\end{array}$

\section{SCOTCH PINE, Pinus sylvestris}

Here is where you get the most Pine for the least money, because they grow fast when young. Scotch Pine makes a big, broad-shouldered tree highly resistant to wind or drought or cold. Our plants are especially fine because they were nipped back two or three years ago to make them broad and dense.

$\begin{array}{rrrrrr}\text { Height } & \text { Each } & \text { Ten } & \text { Height } & \text { Each } & \text { Ten } \\ 4-5 \mathrm{ft} . & \$ \$ .00 & \$ 70.00 & 10-12 \mathrm{ft} . & \$ 35.00 & \$ 300.00 \\ 8-10 \mathrm{ft} . & 25.00 & 220.00 & 12-14 \mathrm{ft} . & 50.00 & 400.00\end{array}$

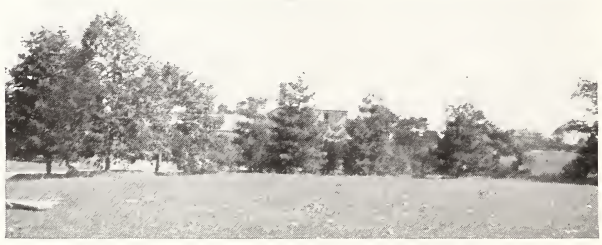

Planting of large Lindens and plants for Mr. Arthur Ryle, Locust Valley, L. I. The trees were selected and planted last September

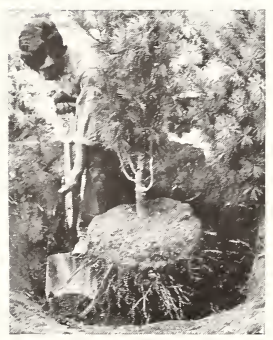

How Hicks trees are dug with a ball of earth. This tree was root pruned a few years previously so there are numerous small feeding roots in the ball of earth. The circle is marked on the ground by a string and peg. The trench is dug by placing the shovel on the radius. The roots are cut off on the outside of the trench. The man goes around the tree several times until the trench is down below the roots

The man on the right is trimming down the ball of earth with a fork to the right taper for the canvas, while the other is shoveling out the loose dirt and making an undercut

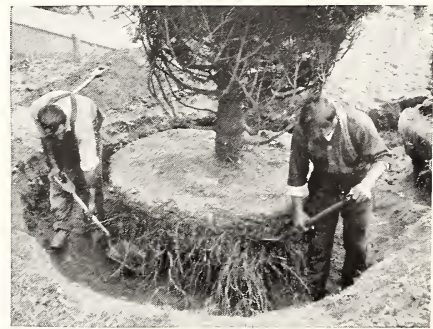




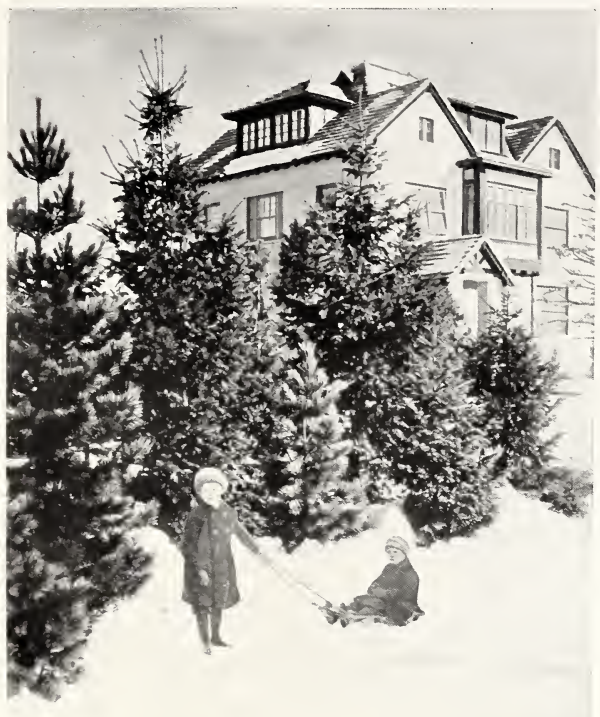

Windbreak of Spruce, Fir and Pine on the grounds of $\mathrm{Mr}$. Meissonier, Garden City, L. I. Each year a Christmas tree can be added or trees taken out to prevent crowding

\title{
THE SPRUCES AND FIRS
}

\author{
(Picea and Abies)
}

HESE are the pointed topped evergreens of Christmas tree shape. The fragrant balsam you know is a Fir. They are native in the mountains. You can use them to make your grove of Christmas trees, enclose a sheltered nook for playground or make a tall and narrow boundary screen.

Your community can pick out a big one for a permanent Christmas tree.

In color the Spruce and Fir range from dark green to the silvery blue of the Colorado Blue Spruce and White Fir, With them you will find new elements for composing your landscape not generally available. Trying to describe the different sizes, ages and colors is not as practical as sending you a branch; then you will see the color and smell the balsam perfume. The best way of all is to spend half an hour looking them over. To make up a carload of shade trees and evergreens, some of these should be included for most landscapes. Suppose you have a place in the suburbs of Buffalo, Rochester, Schenectady, Le Roy, Binghamton, Batavia, Scottsville, Easton, Bethlehem or Reading, you wish a dark setting for the house or natural background for the flower garden; suppose you like to roam out a mong your own trees to see the birds build nests in them and your children play hide and seek among them; suppose you want trees you can look up to, not little things you can pat on the head. These time saving Firs and Spruces are the best investment we know of for you. They are guaranteed to grow satisfactorily.

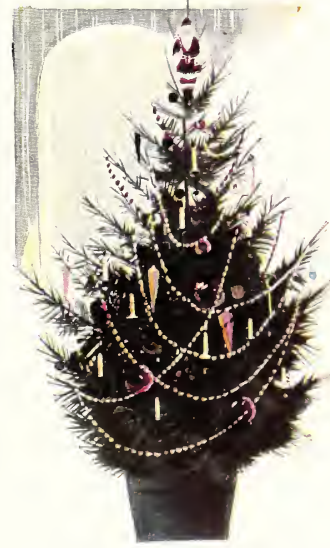

Live Christmas tree to plant after Christmas. It seldom freezes early enough on Long Island to make planting inconvenient. Mulching the planting inconvenient. Mulching the
ground will prevent freezing and permit planting all winter

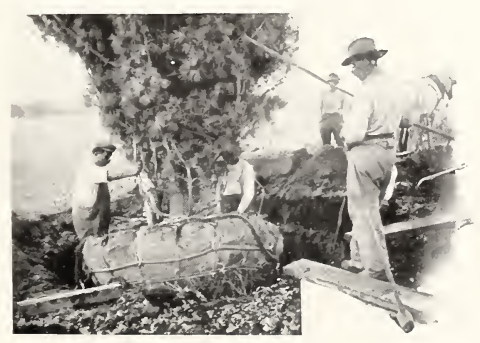

Carload shipments to indicate wide spread service of Hicks time-saving trees. The following are among those who have recently had carload shipments. They find it the most satisfactory way to save time

Jas. B. Neal, Easton, Pa.
E. L. Woodward, Leroy, N. Y. C. W. Woodward, Leroy, N. Y. Ciliver Greif, Baltimore, Md. Oliver Greif, Baltimore, Md. H. T. Hayward, Franklin, Mass. H. T. Hayward, Franklin, Mass. Whilip Wickser, Buffalo, N. Y Philip Wickser, Buffalo, N. $\mathrm{Y}$. $\mathrm{Pa}$ Mrs. J. S. Wood, Beavertown, Pa.

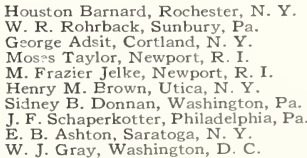

The canvas cover invented by Edward Hicks of Hicks Nurseries clamps the ball of earth securely. Our somewhat boastful statement, "It is the greatest improvement since the Garden of Eden," is based on the fact that with this canvas and men that know how to use it almost any kind of tree can be moved successfully at any time 


\section{DOUGLAS SPRUCE,}

Pseudotsuga (Picea) douglasi

The form of this species native in the high elevations of the Rocky Mountains is at home here. The form from the Pacific slope may winter kill after twenty years. You can keep Douglas Spruce taller and more narrow than most other evergreens, therefore consider the plants fourteen feet high for situations where you need a screen not over ten feet wide. The foliage is a light bluish green, the growth is dense and symmetrical.

$\begin{array}{rcc}\text { Height } & \text { Each } & \text { Ten } \\ 2 \mathrm{ft} . & \$ 4.00 & \$ 35.00 \\ 7 \mathrm{ft} . & 20.00 & 175.00 \\ 8 \mathrm{ft} . & 25.00 & 200.00 \\ 10-12 \mathrm{ft} . & 45.00 & \\ 14-16 \mathrm{ft} . & 70.00 & \\ 16-18 \mathrm{ft} . & 85.00 & \end{array}$

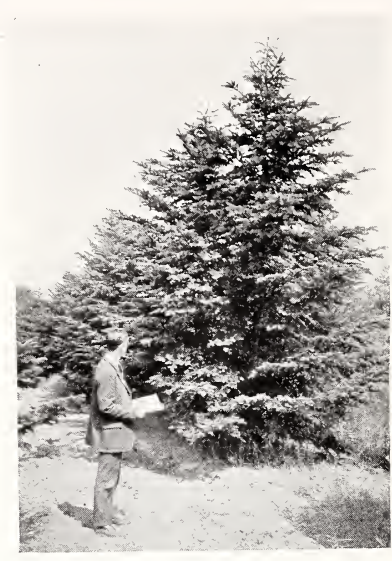

Nikko Fir ready for a community Christmas tree

WHITE FIR, Abies concolor

A big, broad-shouldered, sturdy tree you will be proud to add to your collection. We have sent a carload of these and Douglas Spruce to plant on the shores of Lake Ontario. If you have a place in that latitude or further south you will find them happy.

$\begin{array}{rrr}\text { Height } & \text { Each } & \text { Ten } \\ 1 \mathrm{ft} . & \$ 2.00 & \$ 17.50 \\ 2 \mathrm{ft} . & 2.50 & 22.50 \\ 3 \mathrm{ft} . & 6.00 & 50.00 \\ 5 \mathrm{ft} . & 12.00 & \\ 6 \mathrm{ft} . & 25.00 & \\ 8 \mathrm{ft} . & 40.00 & \\ 10 \mathrm{ft} . & 50.00 & \end{array}$

\section{NIKKO FIR, A. homolepis}

(brachyphy11a)

From the Nikko Mountains in Japan. This tree likes our climate better than its own relative, the Balsam Fir.

\section{COLORADO BLUE SPRUCE, Picea pungens glauca}

A conspicuous tree of bluish or sage green foliage.

$$
\begin{array}{rrr}
\text { Height } & \text { Each } \\
6-8 \mathrm{ft} . & \$ 40.00 \\
10-12 \mathrm{ft} . & 100.00
\end{array}
$$

\section{ORIENTAL SPRUCE, Picea orientalis}

A species from Asia Minor with very dark green foliage. Use it as the dark green background for the others.

\begin{tabular}{rcc} 
Height & Each & \multicolumn{1}{c}{ Ten } \\
$4 \mathrm{ft}$. & $\$ 10.00$ & $\$ \$ 5.00$ \\
$5 \mathrm{ft}$. & 12.00 & 100.00 \\
$6 \mathrm{ft}$. & 25.00 & 220.00 \\
$14-16 \mathrm{ft}$. & 60.00 &
\end{tabular}

\section{SERBIAN SPRUCE, Picea omorika}

A tall, narrow tree that seems to be at home here. The underside of the foliage is blue, giving it a distinctive appearance.

$$
\begin{array}{ccc}
\text { Height } & \text { Each } & \text { Ten } \\
6-8 \mathrm{ft} . & \$ 35.00 & \$ 300.00
\end{array}
$$

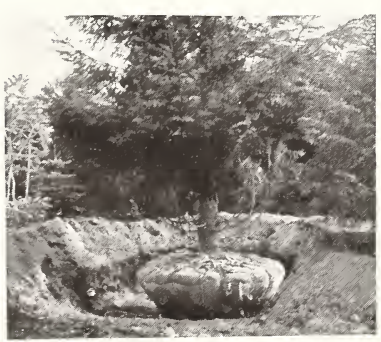

Height Each

$8 \mathrm{ft} . \quad \$ 40.00$

$10 \mathrm{ft} . \quad 50.00$

$12 \mathrm{ft} . \quad 75.00$
Height Each

$14 \mathrm{ft} . \quad \$ 100.00$

$16 \mathrm{ft} . \quad 150.00$

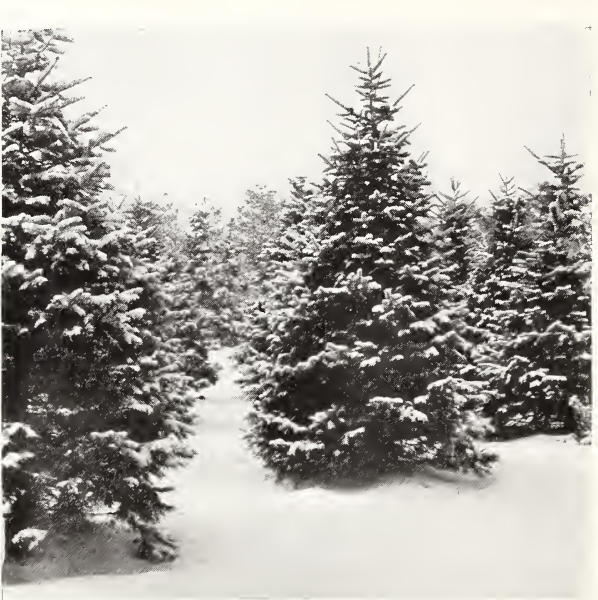

White Firs at Hicks Nurseries. You will find them labeled "Planted June, 1920." The most perfect specimens were selected and they have been grown in the most perfect way for you. A truck load or carload will be a good investment

The tree looks like this when it is in the hole ready for loading or ready for planting. The top of the ball shows intricate lashing of rope to pull up the conical canvas on the conical ball, mak ing it very tight. Burlap is placed under the cross lashing and under the bottom of the ball to prevent the soil sifting out on long journeys

A Christmas tree for your community can be planted at any time of the year. Let your committee call to pick out the tree. The Madison Square Christmas tree, sixty feet high, which we set up for several years, has helped start the movement for community Christmas trees. The trees do not like to be lonesome. You had better make a grove. Under-plant with Laurel, mulch with leaves and have somebody make sure they have a drink every two weeks 


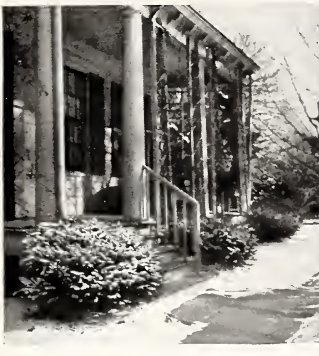

Japanese Yew Flat Form trees at the Hicks homestead. A little pruning makes them as round and velvety as Boxwood
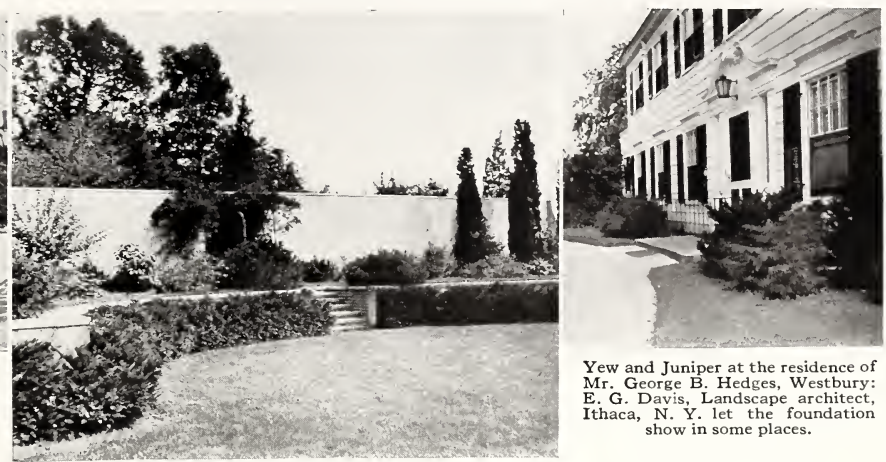

Yew and Juniper at the residence of Mr. George B. Hedges, Westbury: E. G. Davis, Landscape architect, Ithaca, N. Y. let the foundation show in some places.

Japanese Yew Flat Form below the wall in the garden of Mr. Victor Marowetz, Syosset, L. I.

\section{YEW (Taxus)}

F all the evergreens for small places these are pre-eminent. Dark green foliage, not affected by cold or heat, fine texture of foliage and small stature is the technical analysis, but you will have to get acquainted to know why the Yew trees are better for your place. No matter how fully planted, there is room to redecorate with Japanese Yew.

JAPANESE YEW, Taxus cuspidata

Height Each Ten Height Each Ten $\begin{array}{lllll}1 \frac{1}{2} \mathrm{ft} . & \$ 4.00 & \$ 35.00 & 5-6 \mathrm{ft} . \quad \$ 35.00 & \$ 325.00\end{array}$

\section{JAPANESE YEW, Flat Form, Taxus cuspidata}

It is the best plant we know for low green against the house, is perfectly hardy and weaves together in graceful masses, free from the disquieting spikes frequently seen. In late summer and autumn it is thickly hung with clusters of red cups.

\begin{tabular}{|c|c|c|c|c|c|c|}
\hline & & & Height & & & \\
\hline & & & $21 / 2 \times 21 / 2 f$ & & & \\
\hline & & & $\begin{array}{l}3 \times 3 \\
3 \times 4\end{array}$ & & 18.00 & \\
\hline
\end{tabular}

\section{SPREADING YEW, Taxus baccata repandens}

A hardy form of the English Yew making a mound four feet high by two feet broad with graceful arching branches. Put it on the shaded side of your evergreen group or house or among Pines and Hemlocks. Don't set it out as a single specimen on the lawn.

$\begin{array}{cccccc}\text { Spread } & \text { Each } & \text { Ten } & \text { Spread } & \text { Each } & \text { Ten } \\ 1 \times 1 \frac{1}{2} \mathrm{ft} . & \$ 5.00 & \$ 45.00 & 1 \times 21 / 2 \mathrm{ft} . & \$ 12.00 & \$ 100.00\end{array}$

DWARF JAPANESE YEW, Taxus cuspidata nana brevifolia

A compact little mass of green with horizontal or upward arching sprays. Use it to feather down the flat form,

The photograph at the right shows Hicks Japanese Yew, Taxus cuspidata hicksii, which was raised from the seed we collected twenty-four years ago. The drawing shows Irish Yew in an English garden. Hicks Yew is fasti exactly the same frorm as the Irish Yew (Taxus baccata, variet by winter-killing. Add one to your collection. Have the pride of being the first to possess a good new plant
DWARF JAPANESE YEW Continued)

as a little touch of green in the rock garden, through the evergreen garden and for borders in the flower garden.

\begin{tabular}{rrr} 
Height & Each & \multicolumn{1}{c}{ Ten } \\
$\$-10 \mathrm{in.}$ & $\$ 3.00$ & $\$ 25.00$ \\
$1 \times 11 / 2 \mathrm{ft}$. & 6.00 & 50.00 \\
$11 / 2 \times 2 \mathrm{ft}$. & 10.00 & 90.00 \\
$2 \times 2 \mathrm{ft}$. & 15.00 & 125.00
\end{tabular}

\section{HICKS JAPANESE YEW,}

\section{Taxus media hicksi}

A new variety destined to be very popular for its interrogation point form, dark color and hardiness. We discovered it among thousands of seedlings of an old plant in Chas. A. Dana Arboretum, Glen Cove, which is now thirty feet wide and almost as high.

$$
\begin{array}{ll}
\text { Height } & \text { Each } \\
1-11 \frac{1}{2} \mathrm{ft} . & \$ 5.00
\end{array}
$$

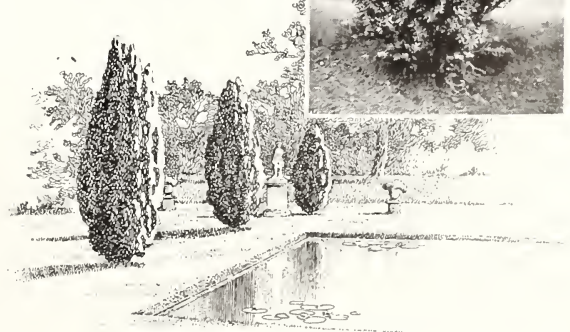




\section{THE JUNIPERS (Juniperus)}

HIS genus contains various low evergreens. 'They all like full sun, while Hemlock, Yew, Holly and Laurel prefer or tolerate shade.

Use the low Junipers on the sunny side of the house to feather down groups of evergreens and shrubs, to cover dry banks, and for rock gardens.

You can become a Juniper fan and even find your own new varieties in pasture and rocky shore.

Don't despise the little plants only a foot wide. They will cover the ground anyway and it is better to plant three little ones than one bigger one. 'The same principle doesn't apply with a broad shade tree or tall evergreen.

Therefore come to the nursery and study them. They are not generally known; we have not pictures of their uses, and pictures do not show their character. A landscape architect said: "It's best to pick out Junipers." In other words, he meant Junipers were not standardized as well as other plants. In summer they can be dug any time. In winter there are some in pots in frames.

\section{COMMON JUNIPER, Juniperus communis}

Saucer-shaped plants frequent in New England pastures. You can get here exceptionally good and cheap plants. They are two to three and one-half feet wide and one to two feet high. Just right for the sunny side of the house or the long horizontal lines that should supplement the vertical lines of many landscape compositions. Have you

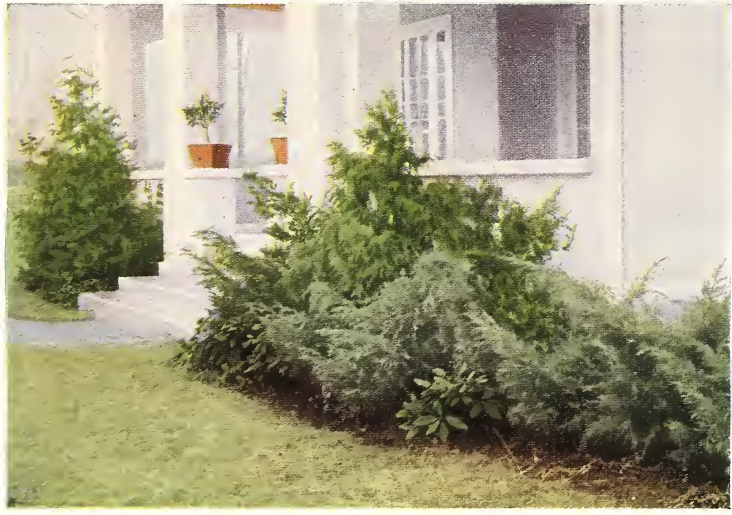

Foundation planting at Plandome, L. I. Pfitzer Juniper, Rhododendron, Japanese Cypress. It's lots of fun to do over the foundation planting. Bring a sketch, photograph or ask a salesman to call

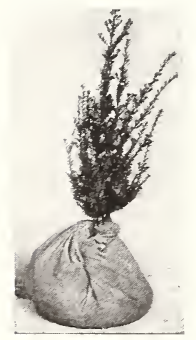

The ball of earth on small trees is held by burlap. This can be tied across like a bandanna handkerchief, as illustrated, or held still better by sewing with binder twine with a needle seven inches long. The picture shows a
Japanese Yew two feet high, illustrating the large balls of earth usually shipped on Hicks small evergreens. You can let the burlap stay on, loosening it at the top. It soon decays

White Pine with ball of earth lashed down to the platform. Thousands upon thousands of these trees have left Hicks Nurseries, and we do not recall a dead White Pine; whereas it used to be a very risky thing to transplant such trees before the invention of the Hicks platform and canvas system. It is now simple and certain

\section{PFITZER JUNIPER, Juniperus chinensis pfitzeriana}

Not saucer-shaped, but taller, like a tea cup in height and spread. The branches are plumy, the color light blue green. It grows about three feet high and equally broad.

$\begin{array}{lll}\text { Spread } & \text { Each } & \text { Ten } \\ 11 / 2 \mathrm{ft} . & \$ 3.00 & \$ 27.50\end{array}$

\section{SHORE JUNIPER, Juniperus litoralis}

On the sand dunes of Japan it holds the sand. It is light green.

$\begin{array}{clc}\text { Spread } & \text { Each } & \text { Ten } \\ 1 \mathrm{ft} . & \$ 2.50 & \$ 20.00\end{array}$

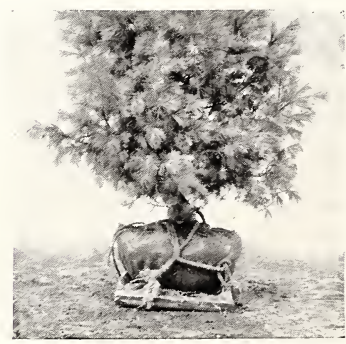




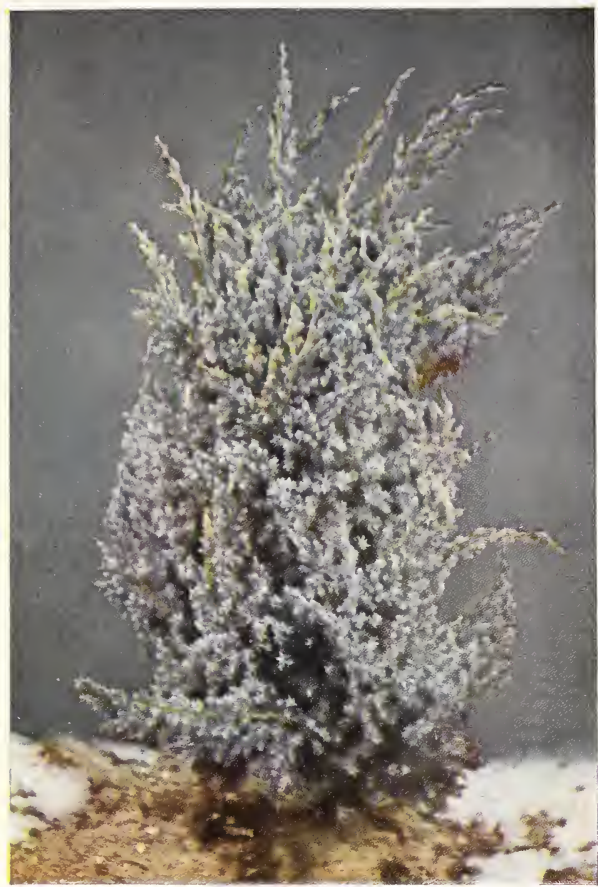

Meyer Juniper

\section{MEYER JUNIPER, Juniperus squamata meyeri}

Introduced by Frank Meyer, agricultural explorer, United States Department of Agriculture. He sent us two plants grafted in China. We are the first to introduce this and regard it as one of the most distinct and beautiful of all the dwarf evergreens. It has a new color combination that is very charming-steel blue and red. The general effect is blue like the Colorado Blue Spruce and White Fir, but look at it closely and there is a tinge of red in the new growth. How big it will get we do not know, but in five years it may be four feet high and three feet broad. Use it on the sunny side of the house, to feather down your taller evergreens or add a bit of contrasting color against the dark background at the end of a vista. If you start collecting evergreens here is a good place to begin.

$$
\begin{array}{crc}
\text { Height } & \text { Each } & \text { Ten } \\
1 \mathrm{ft} . & \$ 3.00 & \$ 27.50 \\
2 \mathrm{ft} . & 6.00 & 50.00
\end{array}
$$

SWEDISH JUNIPER, Juniperus communis suecica

Exclamation points soon becoming three feet high and one foot broad like a stove pipe.

$$
\begin{array}{llc}
\text { Height } & \text { Each } & \text { Ten } \\
11 / 2 \mathrm{ft} . & \$ 2.00 & \$ 17.50
\end{array}
$$

\section{RED CEDAR, Juniperus virginiana}

Tall, spiry Red Cedars along fence rows and in abandoned fields are familiar. To use them in home landscapes requires careful moving with big balls of earth and watering the roots. A strong spray in the evening to knock off the red spider during dry, hot periods is a great help. Cedars have their thin and thick years and this hint of a shower bath is from expert gardeners. Nipping back the tops will also thicken the plants. As mentioned under Juniper they are light-demanding and they may not like a draughty place at the corner of the house or the dryness under the eaves. At the base of the Cedars plant low evergreens and shrubs like common Juniper and Bayberry. We can deliver to you a truck load of Cedars any time of the year and plant them in the best possible manner.

Do you want an evergreen grove thirty feet high as a screen or as a background? Use tall Cedars for the high points. Feather down with White Pine twenty feet, Hemlock five feet and Laurel one foot.

\begin{tabular}{rrr} 
Height & Each & \multicolumn{1}{c}{ Ten } \\
$3 \mathrm{ft}$. & $\$ 3.00$ & $\$ 25.00$ \\
$4 \mathrm{ft}$. & 4.00 & 35.00 \\
$5 \mathrm{ft}$. & 5.00 & 40.00 \\
$6 \mathrm{ft}$. & 6.00 & 50.00 \\
$8 \mathrm{ft}$. & 15.00 & 125.00 \\
$10 \mathrm{ft}$. & 20.00 & 170.00 \\
$12-30 \mathrm{ft}$ & price on application
\end{tabular}

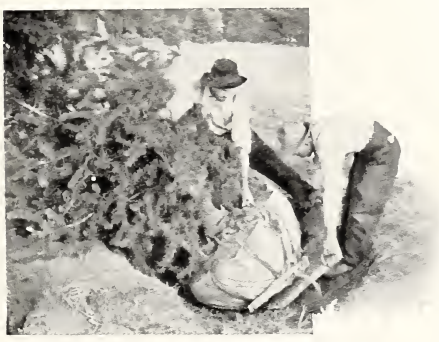

DIRECTIONS FOR PLANTING HICKS TREES DELIVERED WITH BALL OF
EARTH, CANVAS AND PLATFORM

The hole should be dug amply large to work in, about $11 / 2$ feet of space all around the pull out the platform this way. With larger trees pull out the platform by team or tractor

Next straighten the tree and tamp the earth solid under it until it stands vertical. Planteasiest and surest of all planting operations

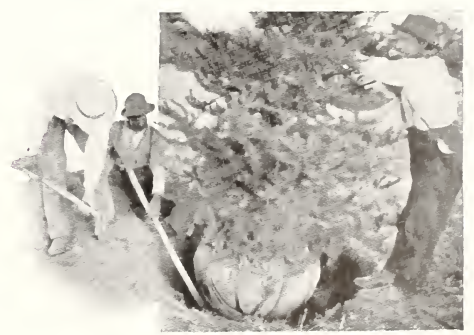




\section{JAPANESE CYPRESS (Retinospora)}

HESE have become more widely planted than any other evergreen from Asia. There are two species in Japan, Sawara Retinospora, light green and plumy from which have been derived blue and golden evergreens, all rapid growing. The other species is Hinoki Cypress, with much darker green foliage, and from it there has been derived a whole series of smaller trees.

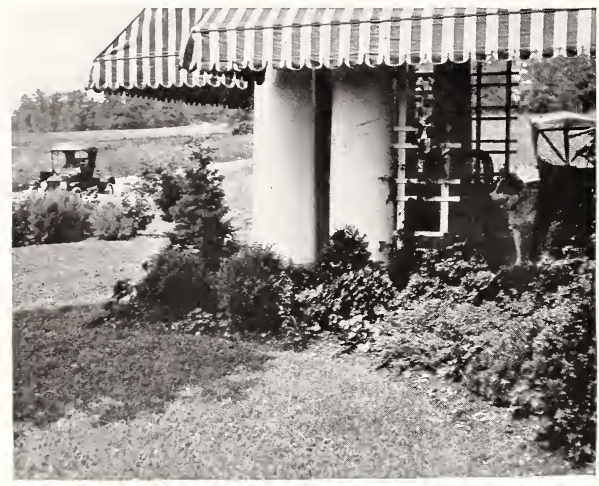

Foundation planting from Hicks Nurseries at Port Washington, L. I. There are three ways to plant the foundation. First-have a representative call, measure the property, submit plan and estimate for delivery and planting. Second-Bring to the nursery a sketch or photograph, pick out the plants. Arrange and plant them yourself. That is the way we like people to do and a way that will give you the fun of being master of your own landscape. Third-Take some standard groups in our sixteen page booklet of "Gardens for Commuters," designed by Chas. D. Lay, landscape architect, New York

\section{PLUME RETINOSPORA,}

Chamaecyparis pisifera plumosa

You will be delighted to take home on the running board of your car a box of these fluffy little green plants. They show in the nursery just how they will look on your place. They are broad, symmetrical and dense, almost as perfect as if they had been made to order of green feathers. The roots are a mass of sponge-like fibre so they are easy to transplant and sure to grow. You can keep them sheared so they do not close your windows, as you of ten see. Better than shearing is to reach in and thin them out. This leaves the natural grace of the foliage. They are frequently used for window boxes.

$$
\begin{array}{rr}
\text { Height, } \begin{array}{r}
1 \mathrm{ft} . ; \\
2 \mathrm{ft} .
\end{array} \quad 3.00 \text {; Ten, } \$ 12.50 \\
25.00
\end{array}
$$

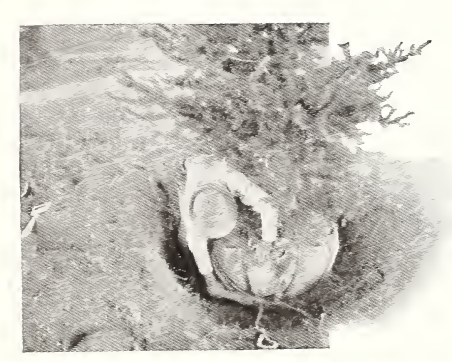

\section{GOLDEN PLUME RETINOSPORA, Chamaecyparis pisifera plumosa aurea}

It is a relief to the eye to see change and contrast. It is especially true on small places where it is not practical to have naturalistic landscapes. Against a background of dark evergreens it will show up the best. You can redecorate the foundation planting around your house, rearrange the little evergreen garden or make a new one with these plants.

$$
\begin{aligned}
& \text { Height, } 1 \mathrm{ft} \text {; Each, } \$ 1.50 \text {; Ten, } \$ 12.50 \\
& 2 \mathrm{ft} \text {. } 3.00 \quad 25.00
\end{aligned}
$$

\section{MOSS RETINOSPORA, \\ Chamaecyparis pisifera squarrosa}

To our mind the brightest blue evergreen in the summer. It's so sprightly and cheerful; brightest of all when sparkling with dew.

$$
\begin{aligned}
& \text { Height, } 1 \text { ft.; Each, } \$ 2.00 \text {; Ten, } \$ 17.50
\end{aligned}
$$

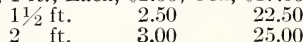

\section{HINOKI CYPRESS,}

\section{Chamaecyparis obtusa}

Shell-like fronds of dark green foliage. Grows to be a tall tree in Japan, but here use it where you want a plant about six feet high.

$$
\begin{array}{rrr}
\text { Height, } & 6-12 \text { in.; Each, } \$ 1.50 ; \\
2 \mathrm{ft} . & 6.00 & \text { Ten, } \$ 12.50 \\
& 50.00
\end{array}
$$

Many more varieties of the Retinospora or Japanese Cypress are at the Hicks Nurseries, but to list them here would be confusing. Come to the nursery, look through the greenhouse and propagating frames, buy the little plants as you would a book for your library. Some have crested foliage like moss, others long fountain-like growth of green or gold.

Do not cut the ropes. Swing the levers over, then the ropes can be easily slipped out of
holes in the levers This lever draws tight the

The earth is so firmly held by the fitted canvas that the ball of earth is held intact. You will readily see that the tree is like a plant in a pot and suffers no serious surgical Pull out the canvas at the bottom a short space at a time, and tamp in the earth to hold the bottom of the ball

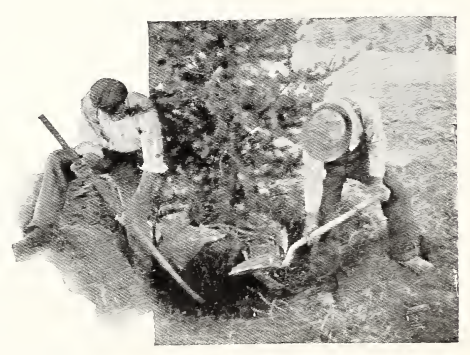




\section{DWARF RETINOSPORA,}

\section{Chamaecyparis obtusa gracilis nana}

Distinctly a darker variety, eminently fitted for dwarf evergreen gardens and foundation planting. You will delight in the deep shadows and crested fronds of happy dark green foliage.

Height, 6-10 in.; Each, \$1.00; Ten, $\$ \$ .50$

\section{Chamaecyparis obtusa magnifica}

Another dwarf form with deep green foliage. They will do well on the shaded side of your house or out in the sunny evergreen garden.

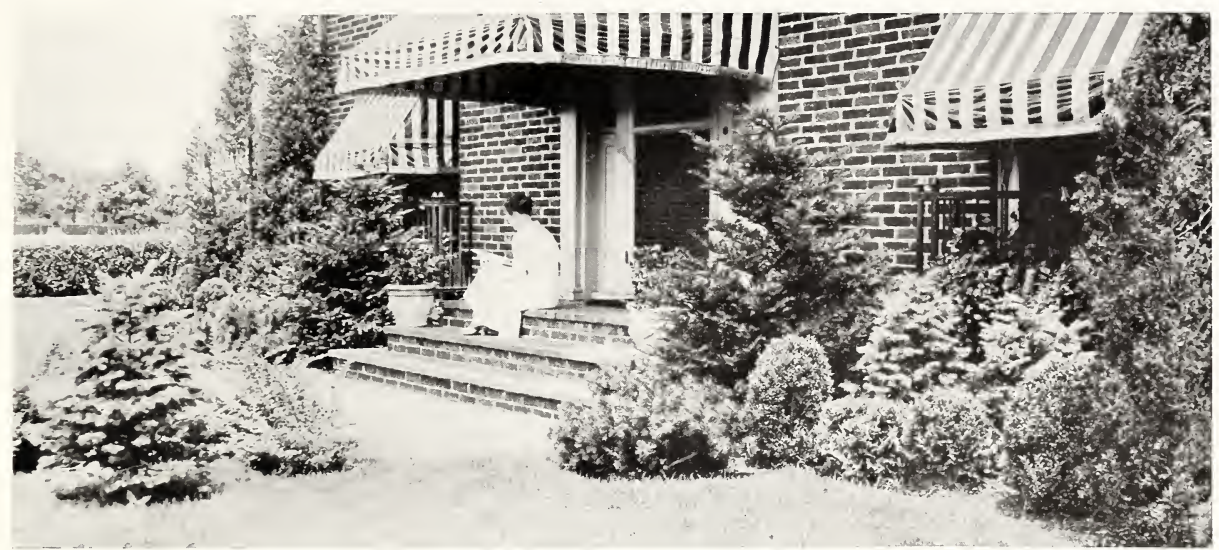

Foundation planting. A group of Red Cedars at the corners. Japanese Yew in the corner of the steps, Mugho Pine in front. Blue Spruce under the window with dwarf Arbor-vitae and Boxwood in front. There are too many kinds and too big. Just time to rearrange

\section{ARBOR-VITAE (Thuja)}

HE White Cedar of the northern New England States, northern New York and Canada. Was once very popular because its fibrous roots permitted transplanting without ball of earth. It prefers the cool and limestone regions and on Long Island begins to look thin and brown in a few years. In the moist, sandy soil along the south shore of Long Island it keeps in fair condition longer.

PYRAMIDAL (DOUGLAS) ARBOR-VITAE,

Thuja occidentalis douglasi pyramidalis

Dense, dark green foliage not unlike the Retinospora obtusa.

$$
\begin{array}{rr}
\text { Height, } 1 \frac{1}{2} \mathrm{ft} \text {.; Each, } \$ 2.00 ; \text { Ten, } \$ 17.50 \\
2 \mathrm{ft} \text {. } & 25.00
\end{array}
$$

BOOTH ARBOR-VITAE,

$T$. occidentalis boothi

A little globe that will stay about one and one-half feet high.

$$
\text { Height, 1-1/2 ft.; Each, \$2.50; Ten, \$22.50 }
$$

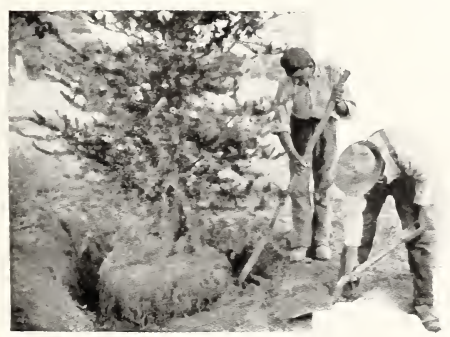

Spread out the side roots in layers and continue filling around the tree, tamping in the earth firmly. Stakes and wires to keep from tipping over are rarely necessary

Mulch with manure. Don't be stingy, and don't veto the be stingy, and don't veto the untidy. If you fear it will blow about or look unkempt, you may cover it with a layer of soil

Mulch is the greatest asset of the human race. Plants support mankind, and plants live on the mulch of decaying vegetable matter. Go into an unburned forest and see the even ten inches deep

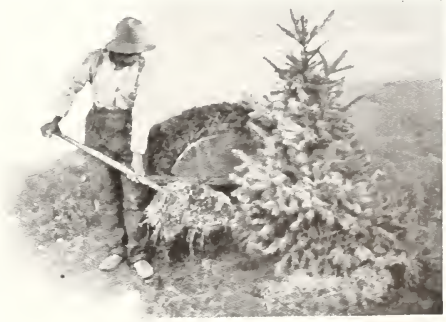




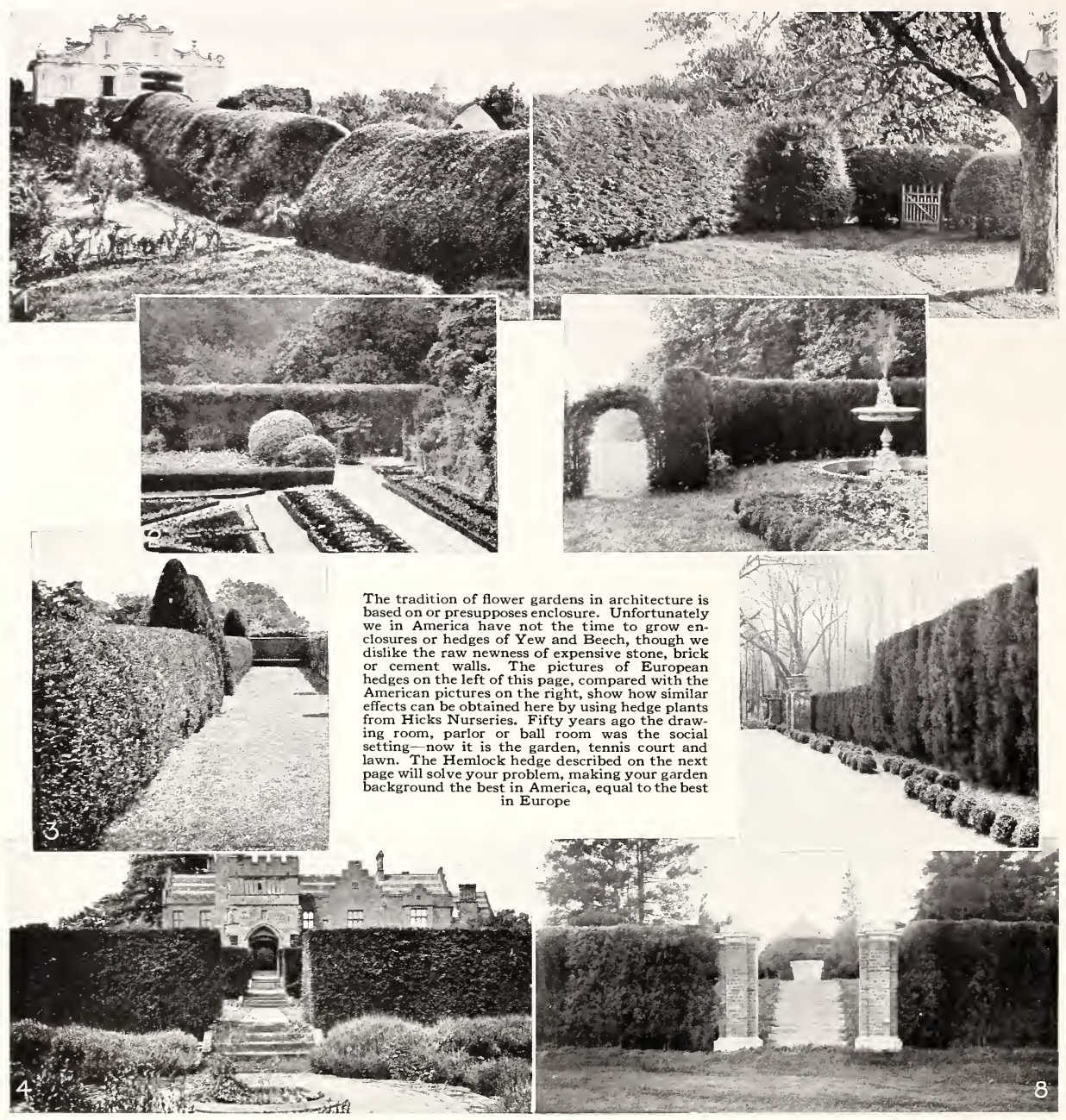

1. A hedge in Italy, where the charm of the gardens depends largely upon the hedges and walls. Hicks Nurseries can help you achieve such results immediately

2. This English Yew hedge is high enough to shut out the view and rouse curiosity to explore the next garden

3. An alley in an English garden hedged by Yew, used as a bowling green

4. At Saighton Grange, Cheshire, England, the gardens are divided by a series of Yew hedges adding charm, mystery and quietness
5. Hemlock hedge at the Hicks homestead to form windbreak on the northeast side of the house. The chickens know the warmth of a wind break for they are sunning themselves at the left

6. Cedar hedge planted by Hicks Nurseries for Mr. Stanley Mortimer, Roslyn House, Roslyn, L. I.

Nathan F, Barrett, landscape architect

7-8. Cedar hedges in the Italian garden of the above estate planted by Hicks Nurseries. Such hedges can be supplied in any quantity at any time, up to $25 \mathrm{ft}$. high, handled in the right way 


\section{A HEMLOCK HEDGE FIFTY YEARS OLD}

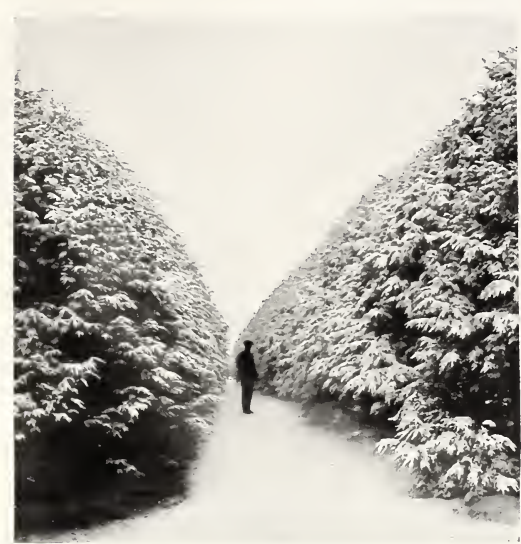

A Hemlock hedge fifty years old for sale in the Hicks Nurseries. It was transplanted a few years ago and is ready to be moved to your estate, adding all the beauty and comfort that trees can shipped by truck, rail or barge

COLR place may need just the finishing touch of this hedge to make a beautiful whole. Perhaps the architect and landscape architect have done their best, but have not known or had the imagination to look for such mature and bea tiful material. Your satisfaction can be that of putting the finishing touches on your place.

Hemlock is native from Canada to North Carolina and Wisconsin. This hedge can be successfully transplanted within this area.

Artists and flower lovers know that the essential part of the picture is the background. You may collect the best roses, dahlias, gladiolus or holly, but they do not look their best when seen against street and adjacent buildings. No background can be better than the soft, velvety texture of this hedge.

Does the entrance court of your house need a frame? Should it be shut off from the flower garden or the service court? Does your house stand up, big, bald and new? Does it need the softening effect of tall shade trees or this hemlock hedge?

You have only to say the word and it will be on your place. Ask your architect and landscape architect to advise you.

Have you a little place in the suburbs of two or three acres, where you want to shut off the street because you cannot afford the time to go an hour further into the country to get quiet? Is there room for good soil fifteen feet wide, two feet deep? We have planted a number of places with evergreens like this. They have solved the problem.

Assume you are a busy business man, your wife and children like the country all the year, you are willing to spend two hours a day in travel and spend a month in the mountains, but you do not want the old-fashioned way of three months in the mountains and nine months in the city. You can put in this hedge, or evergreens of similar height that will shut out the top of the moving vans, shut off the view of your grounds except perhaps from the third story windows. Or you can use

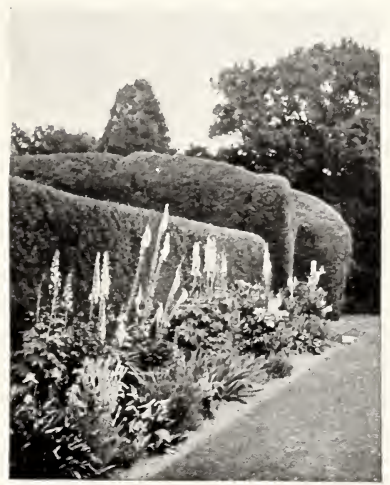

An English flower garden, with a background of Y ew hedge. The Hemlock hedge from Hicks Nurseries can make an equalground for your flowers or garden parties
A garden walk at Coombe Abbey, Warwickshire, England. The Hemlock hedge on this page will add to your garden the same privacy and aristocratic dignity

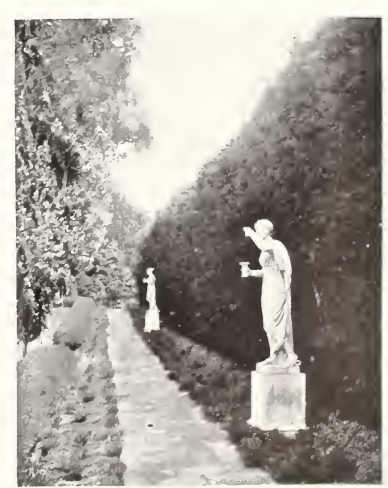




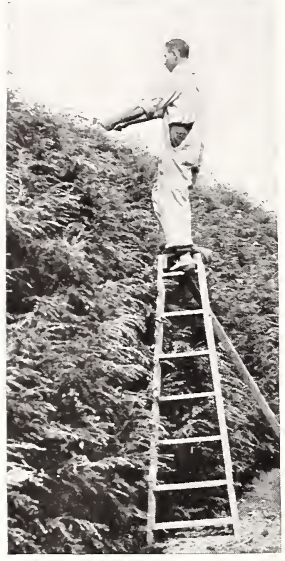

This is how we have been keeping this Hemlock hedge in good condition for your garden. It is accurately measured and lines drawn
keep it in alignment. It is 630 feet long this hedge for part of your boundary and tall pines for another part; it will shut out the noise and achieve your ambition of a quiet little place in the right air and social and educational surroundings, without wasting too much of your time in daily travel.

The best use of your land is to divide it into areas dedicated to various uses. Perhaps this hedge should separate your vegetable garden, garage, stable and service court from your flower garden and lawn. Two or three sides of the house should belong to the family, the balance for entrance court, service court, laundry yard, garage, vegetable garden and orchard. Our guarantee that this hedge will grow satisfactorily means we will study your condition so that you run no serious risk.

It has surrounded the garden of a plant lover. We bought it and when the place was offered for sale moved it to the nursery in August. It has been kept in condition for safe transplanting.

When it is transplanted to your place you can feel you are making the best use of the most graceful evergreen and utilizing the most time saving material for developing your place. Time saving is the greatest material achievement of the age. Those who are users of time saving methods are useful citizens.

\section{HEMLOCK (Tsuga)}

$\longrightarrow \mathrm{HE}$ most graceful evergreen for the northeastern states. It is native on Long Island at The Alley Pond near Douglaston, Port Washington, Oyster Bay and a few other places. There are single plants in the woods. It prefers the north slope of the mountain or the depths of the ravine where it is sheltered from dry winds and bright sun. Plant it among other trees and shrubs and you have one of the happiest and brightest evergreens imaginable.

\section{AMERICAN HEMLOCK, Tsuga canadensis}

For the vista you would like to make through the woods, Hemlocks will do. You can keep them clipped to a vertical wall, although it is better to have them wider at the bottom. Does your woodland look monotonous? Scatter Hemlocks about as you see them in the north woodland.

$\begin{array}{crrcrc}\text { Height } & \text { Each } & \text { Ten } & \text { Height } & \text { Each } & \text { Ten } \\ 3 \mathrm{ft} . & \$ 5.00 & \$ 45.00 & 5 \mathrm{ft} . & \$ 8.00 & \$ 75.00 \\ 4 \mathrm{ft} . & 6.00 & 55.00 & 6 \mathrm{ft} . & 12.00 & 100.00\end{array}$

The Hicks system of root pruning produces a dense, beautiful growth on your grounds because the trees have been root pruned to make numerous fibrous feeding roots in the ball of earth and are dug to save these roots

\section{JAPANESE HEMLOCK, Tsuga diversifolia}

A hardy and sturdy species accustomed to sun and wind. You will find them valuable for foundation planting with Japanese Yew, Holly and Laurel. The foliage is lighter than our native Hemlock.

$\begin{array}{cc}\text { Height } & \text { Each } \\ 2 \mathrm{ft} . & \$ 4.00 \\ 3-4 \mathrm{ft} . & 7.00\end{array}$

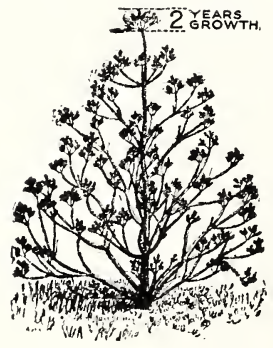

Without the Hicks system the tree may look good in the nursery tree may look good in the nursery make a thin open growth for one or two years or die 


\section{Section III \\ BROAD LEAVED EVERGREENS}

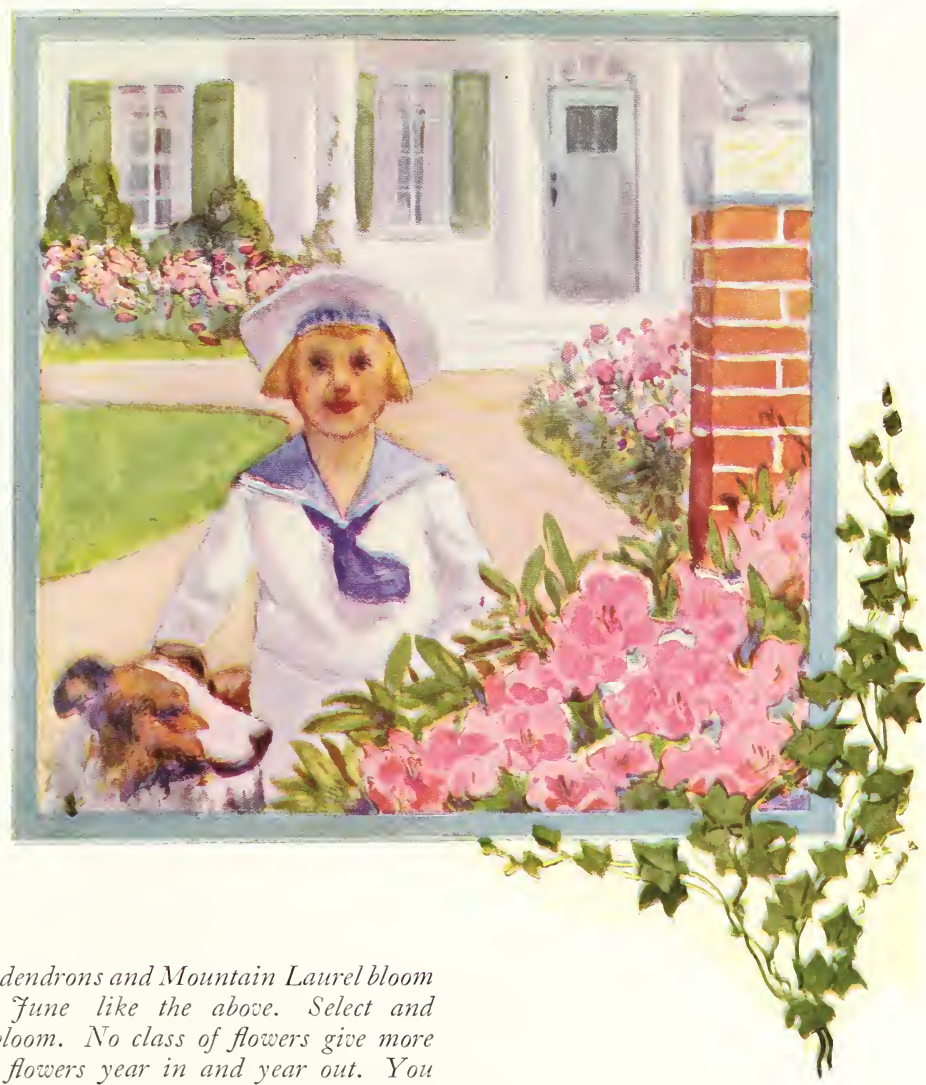

Azaleas, Rhododendrons and Mountain Laurel bloom in May and Fune like the above. Select and take home in bloom. No class of flowers give more in foliage and flowers year in and year out. You can buy small plants, sure to bloom, at low cost. There is little or no uncertainty. They are guaranteed to grow satisfactorily. 


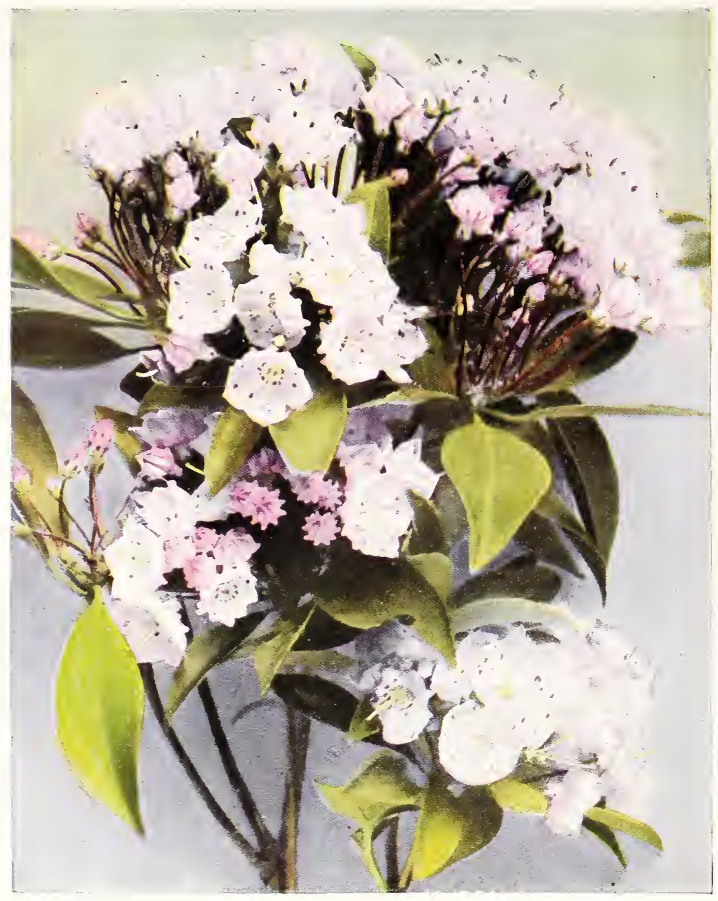

Mountain-laurel can be planted all summer in any quantity. Reproduced from "The Burgess Flower Book for Children," by permission of the publishers, Little, Brown \& Co. (See page 48)

\section{BROAD LEAVED EVERGREENS}

T ON $\mathrm{NG}$ ISLAND is fortunate in having sandy soil free of lime, with a climate tempered by the ocean. A large variety of beautiful foliage, flowers and berries is therefore available.

We have grown this class in large quantity by economical methods and you can get lots of fun with these little plants. Many are in smaller sizes and lower prices than in this catalogue. The best way is to come, see what you are getting, and understand how easily you can arrange them on your grounds. Few other classes of plants, except perhaps the hardy flowers give you as much show and fun for the time and money. You need hesitate no longer for you will see them here in all stages; in little plants smaller than a pin, or big holly and rhododendrons many years old. As a class the soil requirements are simple-decaying leaves, plus the soil you have. We will tell how to grow them on lime stone soil which is not favorable to plants of the heath family or ericaceous plants, Blueberry, Azalea, Rhododendron, Andromeda and Laurel. Boxwood on the other hand grows better when some lime or bonemeal is mixed in the soil.

ABELIA, Glossy abelia

Abelia is a little shrub with pink bells all summer. Protect it with cornstalks or burlap and it will not be killed back. Blooms like a miniature Weigelia, with flowers as pleasant to discover as Arbutus.

$$
\text { Height, 8-12 ft.; Each, \$ .75; Ten, \$6.50 }
$$

\section{AZALEA, Karume and hinodigira}

These are described with the other Azaleas on page $5 \mathrm{I}$. Come and see them because they are the most important addition to early garden color. They hold their foliage during the winter.

\section{BLACK BARBERRY, Berberis gagnepaini}

An upright shrub with dark green leaves, held in good condition through the winter. One of the introductions of the Arnold Arboretum from China to be tested in shady places.

Height, 1-11/2 ft.; Each, $\$ 1.00$
WARTY BARBERRY, Berberis verruculosa

Of the new things from China this has the most interesting foliage. Glossy green and bronze all winter. Orange yellow flowers. Begin the habit of buying little plants in pots or with clumps of earth. Tuck them in where there is room for a plant one foot high at the house foundation or under the evergreens. See Rare Plants, page 60.

Height, $4-6$ in, Each, $\$ 1.00$

\section{BOX, Buxus sempervirens}

The dark green color of Boxwood is best developed by giving it bone meal and not letting it suffer from drought.

Height, 6 in.; Each, \$ .50; Ten, \$ 4.50; Hundred, 335.00 $\begin{array}{llll}1-1 \frac{1}{2} \mathrm{ft} . & 2.00 & 17.50 & 150.00\end{array}$ 
TREE BOX, Pyramidal form

These are trimmed up cone shaped.

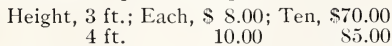

\section{TREE BOX, Bush form}

Bush form.

Height, 2 ft.; Each, $\$ 5.00$; Ten, $\$ 45.00$

HEATHER, (Scotch Heather), Calluna vulgaris

Everybody loves the Heather, but few have thought it available. It has escaped and run wild along the north Atlantic coast. There is no difficulty in its cultivation. It will grow and spread like a great mat of sod. It will grow so thickly as to possess the soil, but never make any trouble by spreading too far. Use it to carpet a sweep of ground. Tuck it in the edge of your foundation planting, to draw out the border of the shrub group. If you have a steep bank use Heather to hold it up. You can come any day of the year and take home Heather in little pots or with clumps of soil. You can find a place for it no matter how small your area.

Each, $\$ .75 ;$ Ten, $\$ 6.50$; Hundred, $\$ 60.00$

\section{WHITE HEATHER, Calluna vulgaris alba}

In Scotland White Heather is rare and highly prized. We have hundreds of plants here that you can pick all summer.

Each, \$ .75; Ten, \$6.50; Hundred, $\$ 60.00$

\section{CALLUNA CUPREA}

It has bronzy red foliage making a pleasant contrast like a low, rich, red velvet. You will find it a pleasure to arrange new gardens with carpet plants.

Each, $8.75 ;$ Ten, $\$ 6.50$; Hundred, $\$ 60.00$

\section{CALLUNA VULGARIS MONSTROSA}

Dark green crested moss-like foliage.

$$
\text { Each, \$ .75; Ten, \$6.50; Hundred, } \$ 60.00
$$

\section{KOCK COTONEASTER, Cotoneaster horizontaiis}

A charming little plant you should not miss. It arches out about two feet wide and eight inches high with bronzy red leaves in winter and fruit like strings of coral. Its flowers in May are like its relative the apple. Plant it at the edge of foundation plantings or borders of evergreens, along a path, against a rock or wall. Come and get it any time; the plants are in pots.

$$
\text { Height, 3-in. pots; Each, \$ .75; Ten, \$6.50 }
$$

\section{ROSE DAPHNE, Daphne cneorum}

A little evergreen about one foot wide with clusters of spicily fragrant pink flowers all summer.

$$
\text { Age, } 2 \text { years; Each, } \$ 1.00 \text { Ten, } \$ 9.00
$$

SHARP LEAF WINTERCREEPER, Euonymus radicans acutus

A variety recently introduced from Japan, with longer and sharper leaves, red in winter.

Each, \$ .50; Ten, $\$ 4.50$
WINTERCREEPER, Euonymus radicans (See page 59)

A creeping vine you can use on walls, to run up the trunks of trees, cover stumps, or carpet the ground. The leaves are perfectly hardy and bright green all winter. It has orange berries like its relative the Bittersweet. Use it freely to border paths and rock gardens, in the woods and in shady places.

$$
\text { Each, } \$ .50 ; \text { Ten, } \$ 4.50
$$

SILVEREDGE WINTERCREEPER, Euonymus radicans argenteo-marginatus

A conspicuous white plant which will give welcome contrast. It can be kept trimmed as a border in the flower garden or planted in the collection of Ferns and other little plants around your rock and stump garden.

$$
\text { Each, } \$ .75 ; \text { Ten, } \$ 6.50
$$

\section{BABY WINTERCREEPER, Euonymus radicans $k \theta-$ wensis}

A diminutive or Tom Thumb variety with leaves oneinch long. Use it as a border to the garden of little evergreens, in the rock garden, in the flower garden or to carpet the ground beside the woodland path.

$$
\text { Each, } \$ .75 \text {; Ten, } \$ 6.50
$$

\section{BIG LEAVED WINTERCREEPER, Euonymus vegetus}

With broad round leaves one inch or more in diameter; can be used both as a creeper or a little dome. It is heavily loaded with orange berries even when the snow is on the ground.

$$
\text { Each, } \$ .75 ; \text { Ten, } \$ 6.50
$$

\section{JAPANESE HOLLY, Ilex crenata}

A bush with leaves the size of Boxwood, and black berries. It occasionally winter kills at the top, but most winters stays such a beautiful dark green that the winter killing is not a veto.

$$
\text { Height, 1-11/2 ft.; Each, \$1.50; Ten, \$12.50 }
$$

\section{INKBERRY HOLLY, Ilex glabra}

A native shrub making a round green bush about three feet high like Box. Has small black berries. Use it in quantity for your evergreen garden and foundation planting; naturalize it along ponds, streams or sand dunes.

Height, $1 \mathrm{ft}$; Each, \$1.25; Ten, $\$ 11.00$

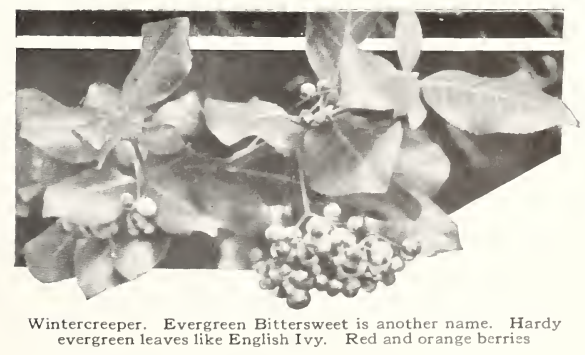




\section{AMERICAN HOLLY, Ilex opaca}

Not many know that this is native along the coast to Massachusetts and that there are occasionally large trees on Long Island. Now that we can offer it to you in all sizes, from twelve inches to twelve feet, you can put it in the woods, make a place among your shrubs and evergreens, use it in your foundation planting and along the seashore.

$$
\text { Height, 2-3 ft.; Each, \$4.00; Ten, \$37.50 }
$$

\section{MOUNTAIN LAUREL, Kalmia}

Here is something you can use by thousands to decorate your woodland, plant in the open lawn or border and under-plant evergreen windbreak or screen, mass it at the foundation of the house or plant it just for its own beauty. You can add it to your commonplace shrub border. You will get extra quality and value. We have big broad shrubs with big balls of earth. You can plant them all summer. All they ask is to have you tuck them in with leaves and give them a drink the first summer. The flowers are abundant in late June, but the crowning glory is the good allthe-year foliage, in soft billowy masses. You will find it a delight to design your landscape with laurel; it is immediately what it is going to be, and is entirely harmonious in this region.

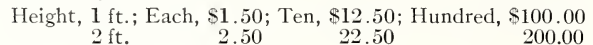

\section{TRUE LABRADOR TEA, Ledum groenlandicum}

On the top of Mount Washington we found cushions of this evergreen with leaves covered like reindeer fur on the under side. It forms a mat about one foot high with white bells like its relative Andromeda.

$$
\text { Height, \$-10 in.; Each, \$ .75; Ten, \$6.50 }
$$

\section{DROOPING LEUCOTHOE, Leucothoe catesbaei}

Evergreen foliage like the Laurel but bronzed in winter. Long arching branches three feet high. Flowers like crowded lily-of-the-valley. Good in sun or shade. Plant it under evergreens, bordering shrubs, in the woods, at the foundation.

$$
\text { Height, 12-18 in.; Each, \$3.00; Ten, \$27.50 }
$$

\section{PARTRIDGEBERRY, Mitchella repens}

In the woods it creeps along the surface, has evergreen leaves marked with white and red berries to satisfy the birds all the winter. The pink flowers are as pretty as Arbutus.

$$
\text { Each, \$ .30; Ten, \$2.50; }
$$

\section{CANBY PACHISTIMA, Pachistima canbyi}

A green cover plant eight inches high. Little leaves, green and bronze. It is native on cliffs in the Alleghanies. Use it in quantity as a green, velvety rug. It is related to Wintercreeper and sometimes called Mountain Lover.

$$
\text { Each, \$ .75; Ten, \$6.50; }
$$

JAPANESE PACHYSANDRA, Pachysandra terminalis

Sometimes called Japanese Spurge. A cover plant with leaves like Laurel growing about eight inches high. Spreads about six inches per year, making an even mat. Use under trees and at the edge of foundation planting. Each, \$ .35; Ten, \$2.00; Hundred, \$18.00

\section{MOUNTAIN ANDROMEDA, Pieris floribunda}

A species native in the southern Alleghanies, makes a compact dome about one foot high. Clusters of white bells appear as if in bloom in the winter. They open early in the spring.

Height, 12 in.; Each, \$3.00; Ten, $\$ 27.50$

\section{CATAWBA RHODODENDRON HYBRIDS, Rhododen- dron catawbiense, hybrids}

Named varieties. Lavender, rose, red and white flowers in early June. Broad evergreen leaves.

Height, 2 ft.; Each, \$8.00; Ten, \$70.00

Seedlings 3 in. $-2 \mathrm{ft}$. high for extensive planting, price on selection.

\section{ROSEBAY RHODODENDRON, Rhododendron maxi- mum}

This species grows from Nova Scotia southward, with big pink flowers in early July.

$$
\text { Height, 11/2-2 ft.; Each, \$3.00; Ten, \$27.50 }
$$

\section{LEATHERLEAF VIBURNUM, Viburnum rhytidophyl-} lum

A new plant from Western China with glossy leaves like Rhododendron Maximum, flat white flowers like Arrowwood and little berries. Try it in sheltered portions of the evergreen garden and in the woods.

Height, 1-2 ft.; Each, \$5.00; Ten, \$45.00

\section{COMMON PERIWINKLE, Vinca minor}

A creeper about six inches high with glossy green leaves, and blue flowers coming with the first violets. Use it as a carpet under evergreens, Oaks and Locust or to border the evergreens and Rhododendrons, for it helps hold the mulch. You can plant it any time and in any quantity.

Each, \$.30; Ten, \$2.50; Hundred, $\$ 20.00$

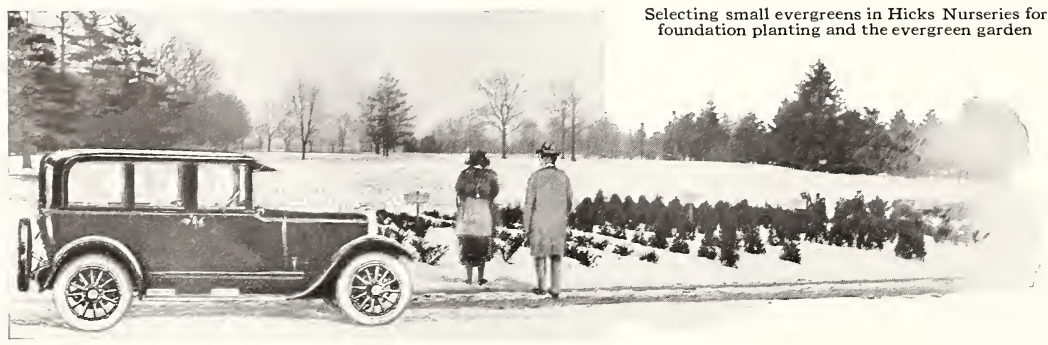




\section{FLOWERING SHRUBS}

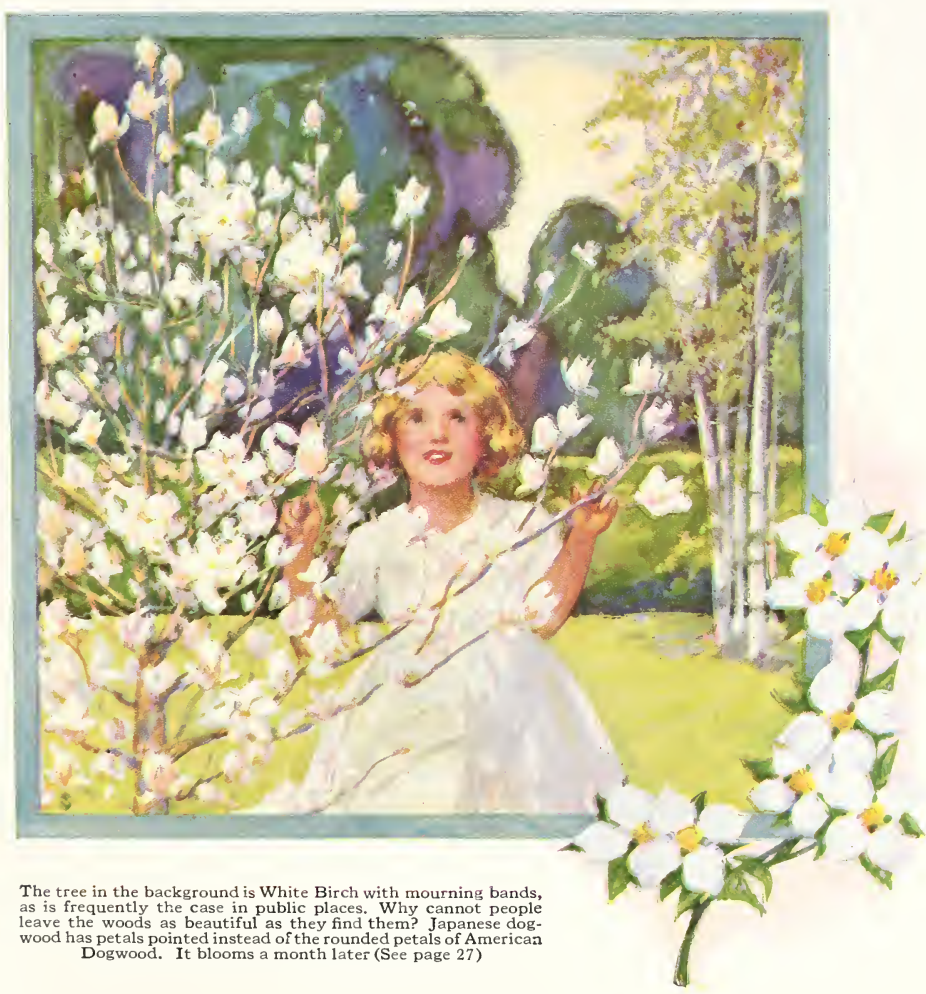




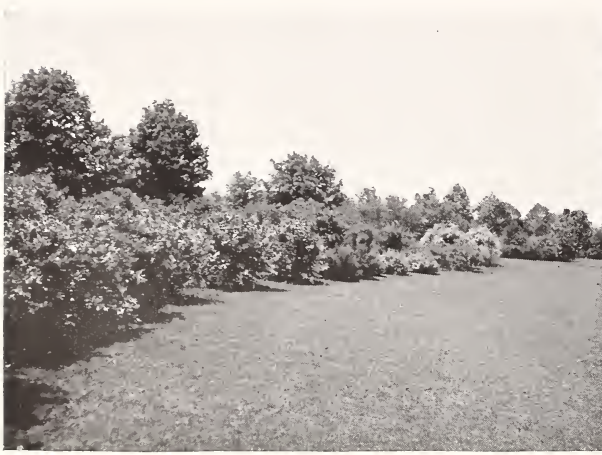

Border of trees and shrubs. Is not this the best way to shut off the street or to separate your property from your neighbor's? We could bring you truck loads of shrubs any time of the year. Most of them transplant successfully in mid-summer. They are big and round like this, not little sticks that you must grow several years. For the summer planting sticks that you must grow several years. For the summer planting
shrubs see Arrowwood, Black Chokeberry, Swamp Azalea, Highbush Blueberry

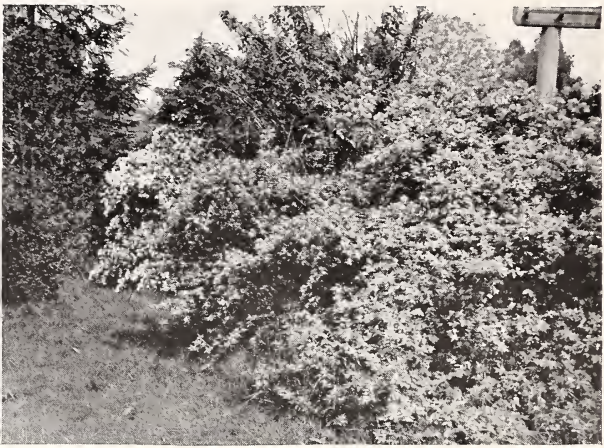

Morrow honeysuckle, broad fluffy masses of white and cream flowers in June, produces red berries soon after, the first of conspicuous berries. The favorite nesting place of catbirds and brown thrush, and their favorite food supply for many weeks

\section{FLOWER AND BERRY BEARING SHRUBS}

YHRUBS are usually plants growing from two to twelve feet high branching with many stems. While called flowering shrubs they should be mainly valued as foliage, the flowers being an incident. You may think of your favorite shrubs with the fragrance of Syringa, Sweet Shrub and Lilac, or the bright colors of Weigelia, Forsythia and Deutzia. You can buy that way and make no mistake. Landscape architects use them in broad sweeps of foliage of ten or twenty of a kind to tie the landscape together, to sketch in the outlines of the lawn, arrange the vistas, or to separate a portion of the ground from another used for a different purpose.

The arrangement of shrubs on your grounds may be what is puzzling you. It need not. Come to the nursery and you will get an idea of the height and spread of the different varieties and so decide whether they should be six or four feet apart. Stake or sketch out on your ground the outline of the shrub border. In your mind plan the high points and the low points. For the tall portions select Arrowwood, Syringa, Deutzia and Dogwood. For the lower portions where you are willing to look over there is another series. For the edge, still another. Sometimes no edging is needed; let the big shrubs tumble over the ground.

Summer planting is practical with most shrubs. They may look a little wilty, some leaves may turn yellow and drop off, but they will pick up and keep on growing and you will find you have had the fun of extending the planting season, and not bothering your memory with something to do next year.

Don't forget things for you and the birds to eat. We have them ready for any time, spring, summer, autumn and much of the winter. Blueberry, Beach Plum, Silverthorn, Shadblow, Cranberry Bush, Black Haw, Hazelnut and a few others for you, and many others for the birds.

\section{TATARIAN MAPLE, Acer tataricum}

The earliest and brightest autumn color with the Virginia Creeper, Dogwood and Liquidambar. It makes a shrub twelve feet high and eight feet broad. Use them for a hedge three feet apart and in mixed planting of shrubs and trees.

$\begin{array}{rrrr}\text { Height, } 2-3 \mathrm{ft} . ; & \text { Each, } \$ .50 ; & \text { Ten, } \$ 4.50 ; \text { Hundred, } \$ 40.00 \\ 3-4 \mathrm{ft} . & .75 & 6.50 & 60.00\end{array}$

\section{SHADBLOW, Amelanchier ovalis}

Sometimes called June-berry. In the Scrub Oaks and Pine barrens we found this delightful sweet berry on bushes about two feet high. It ripens in June before the Huckleberry. One of the first flowers to appear in the spring. It will make a good edging for tall shrubs. (See page 54.)

Height, 1-2 ft.; Each, \$ .50; Ten, \$4.50 


\section{DOUBLE FLOWERING ALMOND, Amygdalis} communis

An old-fashioned shrub with spikes of double pink rosettes about two feet high, among the first in spring.

Height, 1/1/2-2 ft.; Each, $8.75 ;$ Ten, $\$ 6.50$

\section{ARALIA PENTAPHYLLA}

A shrub with inconspicuous flowers but of good foliage, as glossy as the privet and gracefully arching like Vanhoutte Spirea.

Height, 2-3 ft.; Each, $\$ .75 ;$ Ten, $\$ 6.50$

\section{RED CHOKEBERRY, Aronia arbutifolia}

Have you ever found one growing wild. It is rare. The bright red berries were held all winter, almost as showy as the Japanese Barberry. (See page 57.)

Height, 2-3 ft.; Each, \$1.00; Ten, $\$ 9.00$

\section{BLACK CHOKEBERRY, Aronia melanocarpa}

A shrub native in the Pine barrens, Scrub Oaks, hedge rows of the Hempstead Plains and swamps forming a thicket about three feet high. They have juicy black little apples to keep the birds from starving in late winter and early spring. A botanist reports its fruit used for mince pies. Sometimes you eat them by mistake with huckleberries. The white flowers are showy in May. Plant a hundred or a thousand as game cover, to hold the mulch and save the labor of weeding, and on a hillside. As a Privet hedge substitute plant Arrow wood five feet high and this at the base. You can plant them all summer.

Height, 2-3 ft.; Each, \$ .75; Ten, \$6.50; Hundred, \$50.00

\section{AZALEA}

\section{SWEET AZALEA, Azalea arborescens}

Similar to the Swamp Azalea and native in the southern mountains. It is a mound of white flowers in early June.

Height, 1-11/2 ft.; Each, \$1.00; Ten, $\$ 9.00$

\section{FLAME AZALEA, Azalea calendulacea}

Orange and yellow the middle of May. Bartram, the early botanical explorer of Philadelphia, said when they were in bloom it looked as if the woods were afire.

Height, 6-10 in.; Each, \$ .75; Ten, $\$ 6.50$

\section{HINODEGIRI AZALEA, Azalea hinodegiri}

See the picture in the article on Mrs. Bacon's garden. The brightest spot in your landscape in early May. It makes a little low plant one foot high thickly covered with bright carmine red. Give it a mulch of leaves and the shade of other trees and shrubs. Don't expect it to stand out alone like a Bayberry bush. Even if the winter kills it back in part it is worth all your trouble.

$$
\text { Height, 8-10 in.; Each, \$2.50; Ten, \$22.50 }
$$

\section{TORCH AZALEA, Azalea kaemferi}

A shrub three feet high with bright red flowers in May sometimes continuing in to June.

$$
\begin{array}{rrr}
\text { Height, } 6 \mathrm{in.;} \text { Each, } \$ \text {.75; Ten, } \$ 6.50 \\
1 \mathrm{ft} .
\end{array}
$$

\section{CHInese AZAleA, Azalea Mollis}

Large funnel formed, orange and yellow flowers in early May before the leaves appear.

Height, 1-11/2 ft.; Each, \$2.00; Ten, \$17.50
Planting Hazel Nuts in April. This is a hedge Planting Hazel Nuts in April. This is a hedge
on a place in Westbury, $40 \times 100 \mathrm{ft}$. You will
be surprised how much food for you and for be surprised how much food for you and for
the birds there is on this place, Holly, Arrowwood, Red Chokeberry, Apples, Grapes, Rhubarb and vegetables (See page 53)

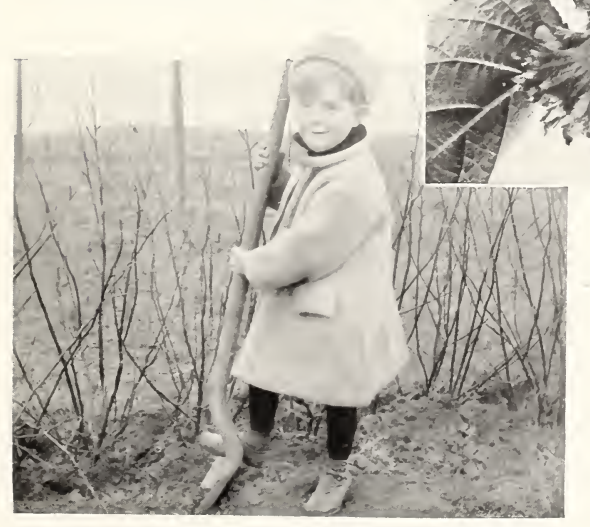

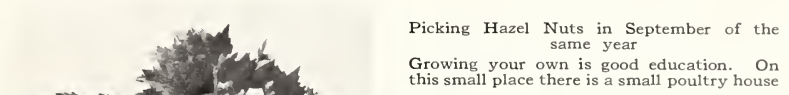

Growing your own is good education. On
this small place there is a small poultry house 


\section{PINXTERBLOOM, Azalea nudifiora}

Some hikers and botanists know where they bloom on Long Island. It is usually on the north slope, protected from dry winds and bright sun. You can plant it in similar places.

$$
\begin{array}{rr}
\text { Height, } 6-12 \text { in.; Each, } \$ .75 ; \text { Ten, } \$ 6.50 \\
1-11 / 2 \text { in. } & 9.00
\end{array}
$$

\section{KYUSHU AZALEA, Azalea obtusa kiusiana}

Better known as Kurume Azalea. Professor Sargent wrote us to come to the Massachusetts Horticultural Society for the first showing of the Kurume Azaleas. He said their introduction is the horticultural event of the century. The colors range from white through varying shades of pink to bright red. We imported by special permit of the United States Department of Agriculture, the six best varieties. We propagated them in quantity, and have them in pots ready for you to take home and plant among your Laurel and Huckleberry in the woods, along a woodland ramble to make a fairy woodland, on the edge of your roads or on the shady sides of the house. Come to the nursery and we will show you how to experiment with them and develop a method of protecting them over winter. Of the many new plants in Hicks Nurseries these are perhaps the most showy. Let us make up a collection and start you on a new series of garden pleasures.

Height, 3-in. pots; Each, \$2.00; Ten, \$17.50

\section{PINK SHELL AZALEA, Azalea vaseyi}

Sometimes called Carolina Azalea. Of all the Azaleas we most highly regard the delicate beauty of this species. Do you remember the pink color of the shells used for ornaments forty years ago? These vary from nearly white through all the shades of pink to a deep pink. The flowers
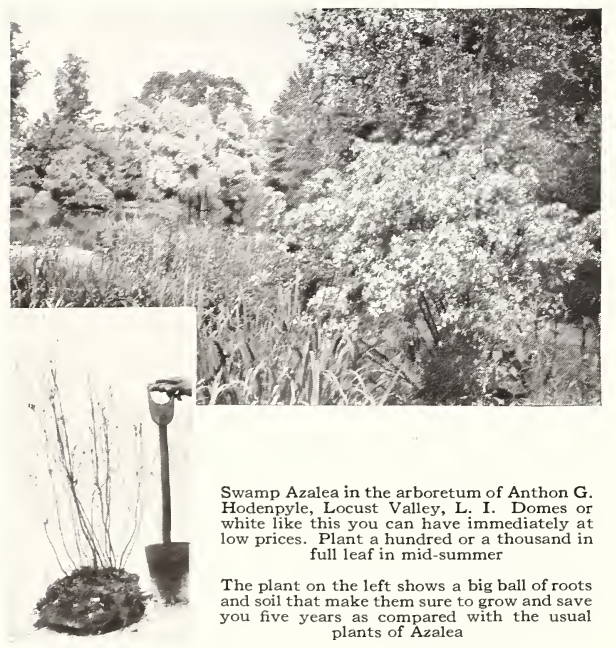

Swamp Azalea in the arboretum of Anthon G. Hodenpyle, Locust Valley, L. I. Domes or white like this you can have immediately at low prices. Plant a hundred or a thousand in full leaf in mid-summer

The plant on the left shows a big ball of roots and soil that make them sure to grow and save you five years as compared with the usual plants of Azalea are large, full and of waxy texture. They come out earlier than the other Azaleas, you will enjoy your gardening season longer for planting them. They don't take up much room. Put them along your woodland walks and drives, on the north side of the house. Plant by the hundred.

$$
\text { Height, 1-11/2ft.; Each, \$1.25; Ten, } \$ 11.00
$$

\section{SWAMP AZALEA, Azalea viscosa}

Here is where you can get tons and tons or truck load after truck load. These plants come up with great big balls of peat as big as a dish-pan. They are sure to grow and grow vigorously. You will get big bushy plants with big roots. The ball of earth will keep it alive and make it bloom vigorously for you the first year.

You will be delighted with the fragrant white and pink tinted flowers that bloom for a month or more. Perhaps you have often caught a whiff of fragrance on a damp evening when crossing the bridges on the Merrick Road; it was the Swamp Azalea and Sweet Pepper Bush. You can plant them in among other shrubs or make a new plantation along your boundary, under your trees, up on the hill or in the valley. Let these be the bulk of your Azalea garden for the first year. 'The combination of these big plants and our little plants at low rates and our knowledge of how to arrange and take care of them will probably give you the most for the money. If you will take up Azaleas we will go a long way to help you because it is lots of fun to introduce a new, more beautiful and economical type of gardening.

Height, 2-3 ft.; Each, \$1.50; Ten, \$12.00; Hundred, $\$ 100.00$

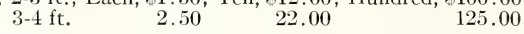

\section{JAPANESE BARBERRY, Berber is thunbergi}

A popular shrub which is a glow of red all winter. A low dome of prickers. For hedges plant one and onehalf feet or two feet apart, for border shrubs four feet apart.

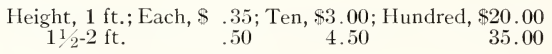

\section{BUTTERFLY BUSH (Summer Lilac), Buddelia}

Rightly named Butterfly Bush for they are fluttering over it most of the time when the sun shines. From June until frost long arching raceums of Lilac flowers. Even if it winter kills it shoots up vigorously the next year.

$$
\text { Age, } 2 \text { years; Each, \$ .50; Ten, \$4.50 }
$$

\section{COMMON SWEETSHRUB, Calycanthus floridus}

Remember the fragrance of the little brown flowers? A shrub four feet high with fragrant flowers in June. Plant in mass at the border of the shrubbery for they will hold the mulch.

$$
\text { Height, 2-21/2 ft.; Each, \$ .60; Ten, \$5.50 }
$$

\section{BLUEBEARD or BLUE SPIREA, Caryopteris}

A shrub one and one-half feet high with blue flowers all summer. The foliage smells like turpentine. They may winter kill, but you will have your money's worth.

$$
\text { Age, } 2 \text { years; Each, } \$ .75 ; \text { Ten, } \$ 6.50
$$




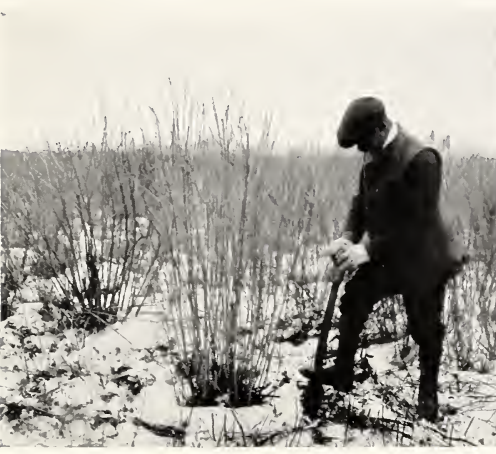

Arrowwood. Big shrubs like this or taller are available as the cheapest, most immediate shrub foliage for you. You see how thick and dense they are, even in winter time they make a screen without leaves. You can use one plant where you would use three, four or five ordinary little shrubs. Consider yourself fortunate that such shrubs are now available and plant them by the hundred all the year for hedge, shrub border, flowers and fruit

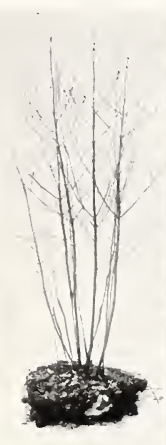

Big ball of earth on this arrowwood shows they carry a full dinner pail always with them. Such a ball of earth permits their safe transplanting all summer

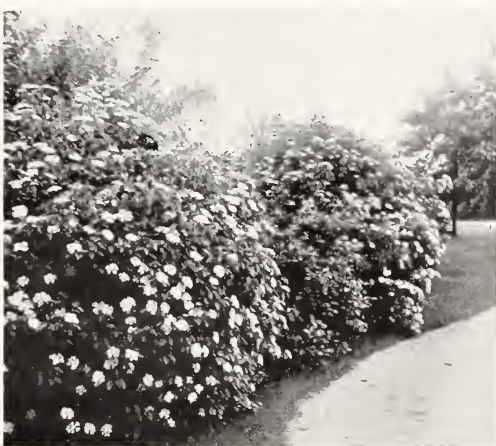

Results like this you can get by planting in full leaf in midsummer. Truck loads and truck loads until your place is hedged off from the street or your laundry yard Waiting till next spring is not necessary. Waiting for little shrubs to grow for five years is not necessary. You can get a $7 \mathrm{ft}$. screen immediately. It is a real economy in height, breadth and beauty (See page 58 )

\section{SUMMERSWEET, Clethra alnifolia}

Sometimes called Sweet Pepper Bush. Spikes of white, fragrant flowers in June and July when most shrubs are out of flowers. It is beloved by the bees. You have probably caught its spicy fragrance crossing the streams along the Merrick road. Use it to add variety and fragrance to your existing shrubbery, under plant grove of trees, make a thicket for the birds and a hedge. For a shelter along the seashore where the soil is moist, mix in other shrubs grown in the same way as Black Chokeberry, Swamp Blueberry and Swamp Azalea. Don't be afraid to use these on the upland and plant all these all summer. (See page 58.)

Height, 2-3 ft.; Each, \$ .75; Ten, \$6.50; Hundred, $\$ 60.00$

\section{DOGWOOD}

\section{For Flowering Dogwood see page 27}

\section{CORAL DOGWOOD, Cornus albasiberica}

Sometimes called Redtwigged Dogwood. The brightest bark in winter. If you cut the older branches to the ground you will get a big growth of bright red twigs. It grows about six feet wide.

$$
\text { Height, } 3 \text { ft.; Each, } \$ .75 \text {; Ten, } \$ 6.50
$$

\section{CORNELIAN-CHERRY, Cornus mas}

A tall shrub with bright yellow flowers earlier than the Forsythia, having cranberry-like fruits in September. Height, 2-3 ft.; Each, \$ .75; Ten, $\$ 6.50$

\section{GRAY DOGWOOD, Cornus paniculata}

Better known as Panicled Dogwood. It has handsome panicles of white flowers in late June and July and has showy white berries in September enticing to the birds.

$$
\text { Height, 2-3 ft.; Each, \$ .75; Ten, \$6.50 }
$$

\section{GOLDENTWIG DOGWOOD, Cornus stolonifera flaviramea}

Sometimes called Yellow Twigged Dogwood. Like the Coral Dogwood, but bright yellow. Use them both to brighten your winter landscape. The twigs are like a yellow pencil.

$$
\text { Height, } 2-3 \mathrm{ft} \text {; Each, \$ .75; Ten, } \$ 6.50
$$

\section{AMERICAN HAZELNUT, Corylus americana}

Do you remember picking these? Plant them in a hedge or in shrubbery, among Oaks and Pines or out on a wind swept hillside. They will take care of themselves, give you or the mice, chipmunks or squirrels an abundant crop. Look for them early, don't wait for frost, September Ioth is better than September 25 th. (See page 51.)

$$
\text { Height, 11/2-2 ft.; Each, s .50; Ten, \$t.50 }
$$

\section{FLOWERING QUINCE, Cydonia japonica}

The old-fashioned Japonica or Fire Bush. It is just as handsome today as it was years ago.

$$
\text { Height, 11/2-2 ft.; Each, S .75; Ten, \$6.50 }
$$

\section{CHINESE QUINCE, Cydonia sinensis}

A big shrub ten feet high with large delicate pink blossoms in late May and fruit like the garden Quince, except a little dryer.

Height, 3-4 ft.; Each, \$1.00; Ten, \$9.00

\section{DEUTZIA}

\section{SLENDER DEUTZIA, Deutzia gracilis}

A little mound of white, two to three feet high. Use it as an edging.

Height, $1 \mathrm{ft}$; Each, $\$ .75 ;$ Ten, $\$ 6.50$ 


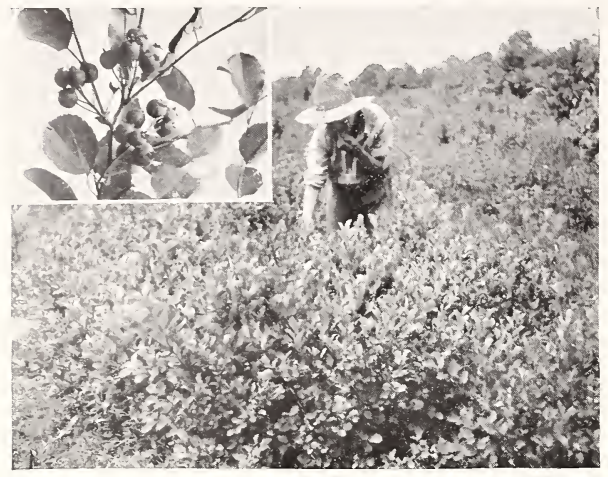

Shadblow. The sweet red berries give it its name of June-berry. It has a mass of white flowers with or before the earliest cherry blossoms. Use it as an edging or cover plant on sandy ground (See page 50)

\section{DEUTZIA, PRIDE OF ROCHESTER}

A tall shrub becoming perhaps eight feet high or more, with pink and white bells.

$$
\text { Height, 2-3 ft.; Each, \$ .75; Ten, } \$ 6.50
$$

\section{EUONYMUS}

\section{WINGED EUONYMUS, Euonymus alatus}

One of the showiest shrubs we know of. It combines the corky ridged bark of sweet gum with the bright foliage of the Tatarian Maple and the abundant brilliant carmine fruit of the Japanese Barberry. Plant a hundred through the woods for the birds, scatter along the edge of your shrubbery, even if you think you haven't room for something new. Try it for a new hedge two feet apart.

$$
\text { Height, 2-3 ft.; Each, \$ .75; Ten, } 86.50
$$

\section{SPINDLE TREE, Euonymus siebolidanus}

A big shrub thickly hung with berries like its relative the Bittersweet. Use them for the tall points in the shrubbery. For a mass underneath taller trees where needed or as a little specimen tree. They will have a heavy burden of little yellow and orange fruit the first year, so you will get good value.

$$
\text { Height, 3-4 ft.; Each, \$1.50; Ten, \$12.50 }
$$

\section{FORSYTHIA}

\section{FORTUNE FORSYTHIA (or Golden Bell), Forsythia fortune $i$}

The first conspicuous and common flowering shrub of spring, sometimes by the middle of April it commences to hang out its festoons of golden bells. It will grow eight to ten feet high and keep perfect foliage all the season.

Height, 2-3 ft.; Each, \$ .50; Ten, $\$ 4.50$

\section{WEEPING FORSYTHIA, Forsythia suspensa}

Like the last, except that it does not grow so high and the long trailing runners take root like Strawberries so that you can use it at the edge of the shrubbery or to hold a steep bank. Sometimes it grows up tall and the branches hang straight down like the Weeping Willow.

$$
\text { Height, 2-3 ft.; Each, \$ .50; Ten, \$4.50 }
$$

\section{WITCH-HAZEL}

\section{VERNAL WITCH-HAZEL, Hamamelis vernalis}

A new species from Missouri blooming in February with small red and yellow blossoms.

$$
\text { Height, 2-3 ft.; Each, \$1.00; Ten, \$9.00 }
$$

\section{COMMON WITCH-HAZEL, Hamamelis virginiana}

A tall shrub from which Pond's Extract is made. It is a mass of fragrant yellow flowers, the last in autumn, holding almost until Christmas.

Height, 2-3 ft.; Each, $\$ .75$; Ten, $\$ 6.50$

\section{BUSH ALTHEA (Rose of Sharon), Hibiscus}

A Hollyhock-like flower in late summer on a shrub ten feet high; white, pink and magenta.

$$
\text { Height, 2-3 ft.; Each, } \$ .75 \text {; Ten, } \$ 6.50
$$

\section{HYDRANGEA PEEGEE, Hydrangea paniculata grandi- flora}

A well-known shrub with big panicles nearly a foot long of white flowers in August. This is not the pink or blue variety that prefers the seashore.

$$
\text { Height, 2-3 ft.; Each, } 8.75 \text {; Ten, } \$ 6.50
$$

\section{ST. JOHNSWORT, Hypericum densiflora}

A low shrub two feet high with yellow flowers in midsummer. Plant at the border of the shrubbery.

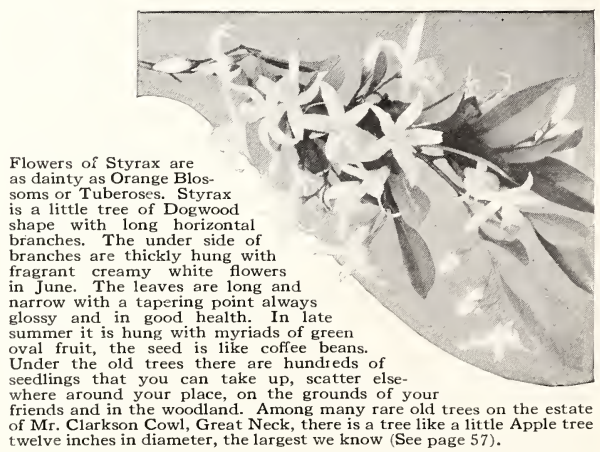




\section{COMMON WINTERBERRY, Ilex verticillata}

The bright holly-like berries hold on all winter; you occasionally see them in a hedge row or swamp. Plant them among the trees and shrubs where you will find them on a winter walk.

Height, 2 ft.; Each, $\$ .50 ;$ Ten, $\$ 4.25$

\section{PRIVET}

\section{CALIFORNIA PRIVET, Ligustrum ovalifolium}

The most popular hedge is California Privet. It grows quickly, has deep green foliage held late in autumn. Plant one foot apart and cut back to an even height.

Height, 2-3 ft.; Each, \$ .25; Ten, \$2.00; Hundred, \$15.00

\section{IBOTA PRIVET, Ligustrum ibota}

It is hardy north and inland where the California Privet occasionally winterkills. It bears abundant black fruit so thick as to be conspicuous all winter. The birds like it in early spring.

\section{Height, 2 ft.; Each, $\$ .50$; Ten, $\$ 4.50$}

\section{REGEL PRIVET, Ligustrum regelianum}

A shrub with the habit of Japanese Barberry. The lower branches arch downward and always cover the base. Excellent for low mass plantings.

Height, $4 \mathrm{ft}$; Each, \$1.50; Ten, \$12.50

\section{HONEYSUCKLE}

\section{MORROW HONEYSUCKLE, Lonicera morrowi}

Similar to the Tatarian Honeysuckle except that its foliage is gray green and the flowers yellow and cream colored. It spreads out more widely and therefore you can put it six or eight feet apart.

\section{Height, 2-3 ft.; Each, \$ .75; Ten, $\$ 6.50$}

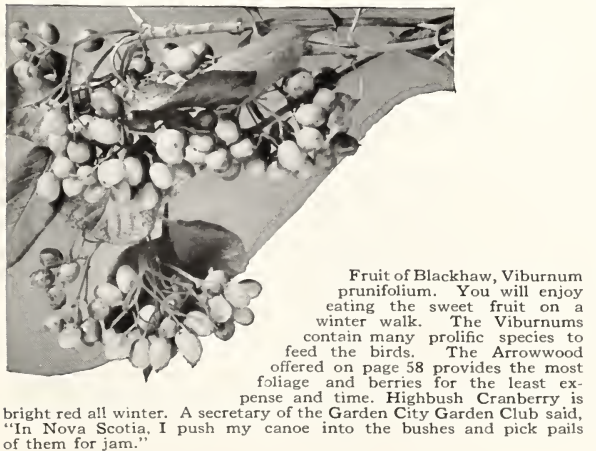

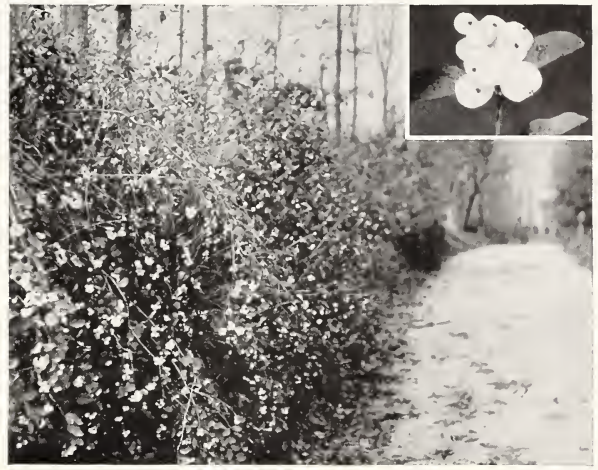

Snowberry on a bank. The pithy white berries are decorative in late summer and autumn. Children like to play with them

\section{MANCHURIAN HONEYSUCKLE, Lonicera ruprech- tiana}

A big broad shrub with pink flowers in May and red berries in July.

$$
\text { Height, 2-3 ft.; Each, \$ .75; Ten, \$6.50 }
$$

\section{TATARIAN HONEYSUCKLE, Lonicera tatarica}

Other names are Upright Honeysuckle and Bush Honeysuckle. What the catbirds and robins call it we do not know, but it is their principal food supply in July and August, when it is heavily laden with juicy currant-like bitter fruit. The flowers are bright pink or white the first half of May. You will like also its broad-shouldered oaklike branches. It grows ten feet high.

Height, 2-3 ft.; Each, $\$ .75 ;$ Ten, $\$ 6.50$

\section{NORTHERN BAYBERRY, Myrica carolensis ( $M$. cerifera)}

This common shrub is a pioneer on abandoned fields and sand dunes. The white wax-covered berries were used by the early settlers for candles. The birds like them. They are decorative for the house both for the berries and for the glossy, shiny foliage. Use it with Beach Plum on the sand dunes. Use it to feather down your shrub groups. Let it carpet a hill of Pine and Oak. It will hold the leaf mulch as mentioned in the preface of shrub department.

$$
\text { Height, } 2 \text { ft.; Each, \$ .75; Ten, \$6.50 }
$$

\section{SWEET MOCK ORANGE, Philadelphus coronarius}

This is the big, sweet white flowers that you remember. It will make a shrub eight or more feet high, gracefully arching under its burden of white flowers in late May or early June. Sometimes called Syringa.

Height, 2-3 ft.; Each, $\$$.75; Ten, $\$ 6.50$ 


\section{PHOTINIA VILLOSA}

The birds soon strip off its clusters of sweet red berries in October. The fruits are miniature apples like the Shadblow and Chokeberry. It grows ten feet high. This is one of three showy autumn berries introduced by the Parsons Nursery, now Kissena Park, Flushing. The others are Symplocus paniculata, Asiatic symplocus or Turquoise Berry and the Japanese Bittersweet or Celastrus orbiculatus. We have helped rescue these from oblivion.

$$
\begin{array}{rrr}
\text { Height, } 2 \mathrm{ft} . ; & \text { Each, } \$ 1.00 \text {; Ten, } \$ 9.00 \\
3 \mathrm{ft} . & 1.50 & 12.50
\end{array}
$$

\section{BEACH PLUM, Prunus maritima}

Now you have a chance to plant something small and cheap that will take care of itself on poor sandy ground and be good to eat. Beach Plum jam is a good spread for bread. Make a hedge as does Edwin Foster, Central Park, near Farmingdale, Long Island, who finds them profitable in the Pine barrens. Plant them as fruit in the orchard. Plant them to hold a drifting sand dune. Use them for reforesting and undercover. Plant them for game cover.

Look through the fruit on your plants and in the wild for better varieties. You may get something comparable in value to the improved Whitesbog Blueberry.

Height, 11/2-2 ft.; Each, \$ .50; Ten, \$4.50; Hundred, $\$ 35.00$
$3 \mathrm{ft}$.
.75
6.50
60.00

\section{NANKING CHERRY, Prunus tomentosa}

A low round shrub about four feet high with myriads of bright pink flowers in early May. Use them for a hedge two feet apart. Add to your shrubs, put them out with the Beach Plum in the wild. We have been fortunate to get a quantity and want to pass on the good luck to you. If you can use a hundred you will enjoy the big sweep of color at the earliest date. You and the birds will enjoy the fruit.

$$
1 \text { year seedlings }
$$

Height, 6-\$ in.; Each, \$ .25; Ten, \$2.00; Hundred, $\$ 15.00$

\section{DOUBLE FLOWERING PLUM, Prunus triloba}

This is similar to the old-fashioned Flowering Almond you occasionally find around cellar holes with spikes of double pink before the Peach blooms. They are bright pink, warm and cheerful, when you are bringing in your first garden flowers. Put them in the flower garden, shrubbery or at house foundation. See color picture in "Gardens for Commuters," a separate catalogue sent on request.

$$
\text { Height, 2-3 ft.; Each, \$1.50; Ten, \$12.50 }
$$

\section{KOREAN RHODODENDRON, Rhododendron mu- cronulatum}

Similar to R. Dahuricum. Here is your opportunity to get one of several earliest spring flowers that you have not had before. It is a hardy deciduous shrub growing four feet high with pink rose purple flowers in March. Use them in your woods, in the Rhododendron and Azalea garden, and among the shrubs.

Height, 1-1 1/2 ft.; Each, \$1.50; Ten, \$12.50

\section{JETBEAD, Rhodotypos kerrioides}

Better known as White Kerria. Light green foliage; single white flowers. One of the conspicuous flowers in its period.

Height, $1 \frac{1}{2} \mathrm{ft}$; Each, $\$ .50 ;$ Ten, $\$ 4.50$

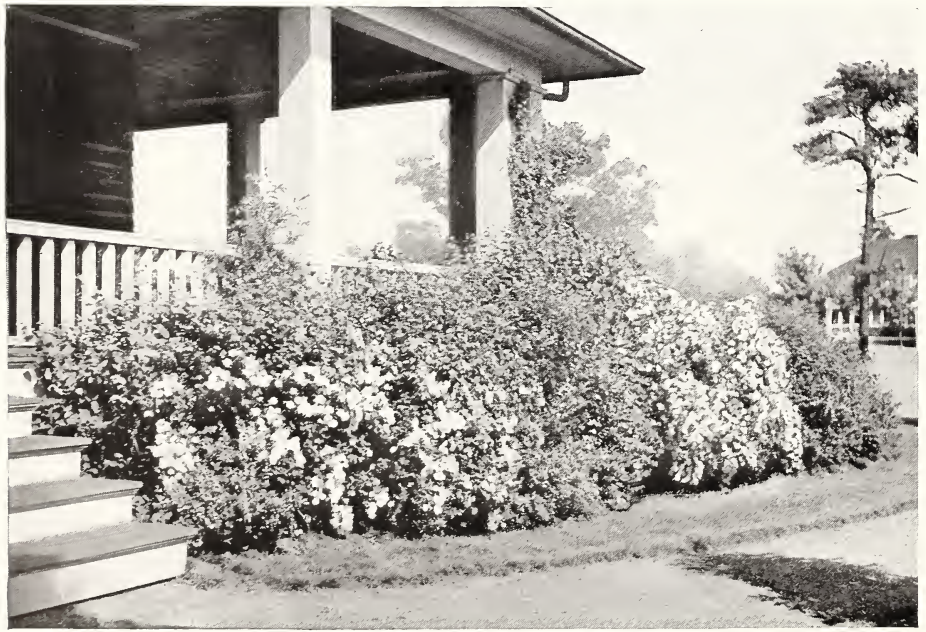

Foundation Planting at Brightwaters, Long Island. A few shrubs like Vanhoutte Spirea, Arrowwood and evergreens like the Cedar at the corner decorate the foundation cheaply in harmony with small cottages. The old Pitch Pine on the right shows how this development was carved out of a forest along a stream on the south side of Long Island. There is room on Long Island for thousands of such residential colonies 


\section{Berberry \\ 2. Japanese Dogwood \\ 3. Arrowwood \\ 4. Red Chokeberry \\ 5. Silver Thorn}

The bluebird does not need a name. The bluebirds and robins and many other insect eating birds would starve if they did not have would starve if they did not have berries when they first come north in the spring. At the Arnold Arboretum a representative of th U.S. Department of Agriculture counted over 140 species of berrybearing trees and shrubs in winter. We have seen mocking birds there in March. L. O. Howard, in hi presidential address before the American Association for the Ad vancement of Science, on the Warfare between Man and Insects, emphasizes how close is the struggle. As entomologist, U. S. Dept. of Agriculture, he knows

We will be glad to help your game preserve or your community to plan out an economic supply of bird food. The American Association of Audubon Societies will be glad to help you

\section{RUGOSA ROSE, Rosa rugosa}

The fruit is like big red apples. The flowers are white or rose pink. Use a dozen or more in shrubbery or on the sea shore.

Height, 2 ft.; Each, $\$ .75$; Ten, $\$ 6.50$

\section{JAPANESE PUSSY WILLOW, Salix multinervis}

The earliest pussy willow and the largest. Often in bloom when you are skating in February. The school children will keep it broken down.

Height, 1-2 ft.; Each, \$1.00; Ten, \$9.00

\section{SPIREA}

\section{ANTHONY WATERER SPIREA}

Almost approaches the Geranium in continuous bloom. It is a low shrub two to three feet high with a flat cluster of bright rose pink or red flowers.

$$
\text { Height, 1-11/2 ft.; Each, \$ .50; Ten, } \$ 1.50
$$

\section{THUNBERG SPIREA, Spirea thunbergi}

A fluffy little white snow drift three feet high in early May. The leaves are beautifully tinted in the autumn.

$$
\text { Height, 2-3 ft.; Each, } \$ .75 \text {; Ten, } \$ 6.50
$$

\section{VANHOUTTE SPIREA, Spirea van houttei}

The most commonly used and generally beloved Spirea. It is a fountain of white the latter part of May.

$$
\begin{array}{rrr}
\text { Height, } 11 / 2 \mathrm{ft} . ; \text { Each, } \$ .50 ; \text { Ten, } \$ 4.50 \\
2-3 \mathrm{ft} .
\end{array}
$$

CUTLEAF STEPHANANDRA, Stephanandra flexuosa A low shrub with fleecy foliage like Thunberg Spirea. Height, 11/2-2 ft.; Each, \$ .60; Ten, \$5.50

\section{JAPANESE STYRAX, Styrax japonica}

A shrub or little tree hung with orange-like blossoms in June. Coffee-like berries in winter.

$$
\text { Height, } 2 \text { ft.; Each, \$1.00; Ten, } \$ 9.00
$$

\section{ASIATIC SWEETLEAF, Symplocus paniculata}

Better known as Turquoise or Sapphire Berry. Robin's egg blue berries in early autumn. Very rare.

Height, 2-3 ft.; Each, \$2.00; Ten, \$17.50

\section{SNOWBERRY, Symphoricarpos}

Do you remember white marbles in September and October on bushes three feet high? It is an old-fashioned shrub. Naturalizing it in the woods or along a hedge row will give the birds a treat. Put it along your drive for the fun of catching a new note.

Height, 2 ft.; Each, $\$ .50$; Ten, $\$ 4.50$

\section{CORALBERRY, Symphoricarpos vulgaris}

Sometimes called Indian Currant. One of the best things we know of for a tangle to hold a bank or to hold the leaves at the edge of a mass of shrubs or trees.

No plant has more berries per cubic foot than this. They are crowded in ropes and look much like the oldfashioned coral beads. Ask us for other berry bearing shrubs to continue the food supply to the birds and the pleasure to your eye.

Height, 11/2-2 ft.; Each, \$ .50; Ten, $\$ 4.50$

\section{LILAC}

\section{LILAC, Syringa}

An old fashioned shrub beloved for fragrance. Don't depend on Lilacs for the big bulk of your shrub foliage for they are not as much at home here as in heavier soils. Use Arrowwood and Blueberry.

COMMON LILAC, Syringa vulgaris

Height, 3-4 ft.; Each, \$1.00; Ten, \$9.00

For names of varieties of Lilacs, see page $6 I$

HIMALAYAN LILAC, Syringa emodi

Showy pink flowers later than common Lilac and without its fragrance.

$$
\text { Height, } 3 \text { ft.; Each, } \$ .75 ; \text { Ten, } \$ 6.50
$$

\section{PERSIAN LILAC, Syringa persica}

Pale lilac flowers that gracefully bend their slender branches.

Height, 2-3 ft.; Each, \$ .75; Ten, $\$ 6.50$ 
HIGHBUSH BLUEBERRY (Swamp Blueberry), Vaccinium corybosum and BLACK BLUEBERRY, Vaccinium atrococcum

These two species are abundant on Long Island. It is difficult to tell them apart. The Highbush Blueberry has blue fruits and the Black Blueberry has black fruits that are sweeter and a few days earlier. For the improved varieties of Highbush Blueberry see Whitesbog Blueberry in the Fruit Department, page 78.

We are here offering Blueberries as ornamental shrubs and for food. Plant them for a hedge. They will grow six or eight feet high. The beauty of the Blueberries as an ornamental shrub on the upland is known to but few.

We strongly advise you to plant them in summer in quantity. We can deliver truck loads with balls of earth.

Height, $3 \mathrm{ft}$.; Each, $\$ 2.00 ;$ Ten, $\$ 17.50 ;$ Hundred, $\$ 125.00$
400.00 $\begin{array}{llll}4 \mathrm{ft.} & 3.00 & 27.50 & 200.00 \\ 5 \mathrm{ft} . & 4.00 & 35.00 & 225.00\end{array}$

\section{AMERICAN CRANBERRY BUSH, Viburnum americana}

Native in the northern part of the United States. The big clusters of Cranberry-like fruit hang on all winter. They are said to make good jam.

$$
\text { Height, 2-3 ft.; Each, \$ .75; Ten, } \$ 6.50
$$

\section{CANBY VIBURNUM, Viburnum venosum canby $i$}

Related to the Viburnum dentatum, Arrowwood, but more dense and compact a shrub, blooming somewhat later.

$$
\text { Height, 2-3 ft.; Each, \$ .75; Ten, \$6.50 }
$$

\section{ARROWWOOD, Viburnum dentatum}

In May a mass of white blossoms like their relative the Snowball. In September and October the birds feast on the bluish black berries. Use for the big shrubs at the corners of the house. Plant all summer. You can plant a thousand in mid-summer for immediate results. (See page 53.)

\begin{tabular}{lrrr} 
Height & Each & \multicolumn{1}{c}{ Ten } & Hundred \\
$2-3 \mathrm{ft}$. & $\$ .75$ & $\$ 6.50$ & $\$ 60.00$ \\
$3-4 \mathrm{ft}$. & 1.00 & 9.00 & 75.00 \\
$4-5 \mathrm{ft}$. & 1.50 & 12.50 & 110.00 \\
$5-6 \mathrm{ft}$. & 2.00 & 17.50 & 150.00 \\
$6-7 \mathrm{ft}$. & 3.00 & 27.50 & 250.00
\end{tabular}

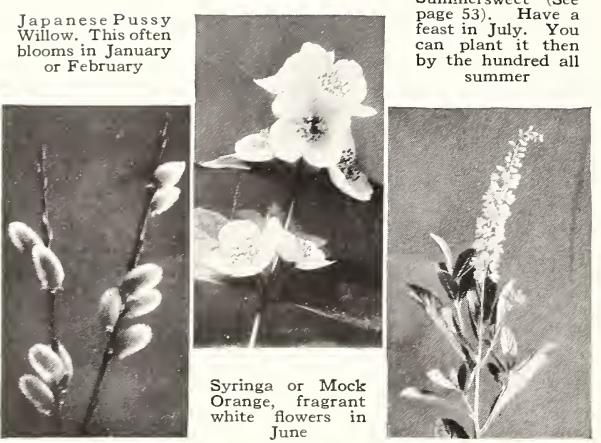

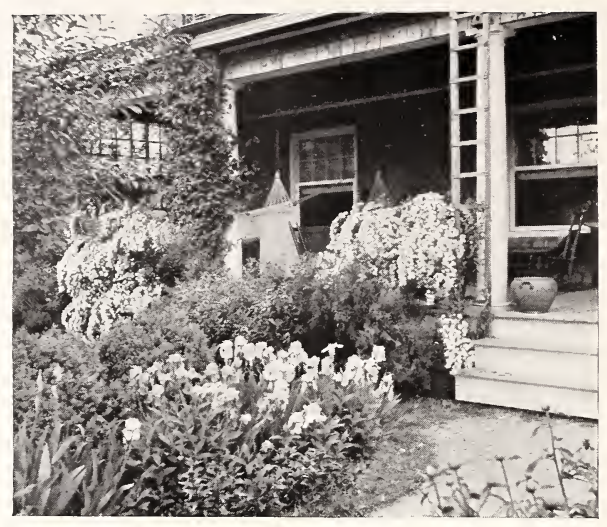

Pretty planting like this could be made almost anywhere, almost any time, with Van Houtte Spirea, Climbing Rose, Iris and Peony

\section{EUROPEAN CRANBERRY BUSH, Viburnum opulus}

One of the most useful berry-bearing shrubs, the fruit remaining all winter.

Height, 2-3 ft.; Each, \$ .75; Ten, \$6.50

\section{COMMON SNOOWBALL, Viburnum opulus sterilis}

An old-fashioned shrub with balls about three inches in diameter at Decoration Day.

Height, 2-3 ft.; Each, \$ .75; Ten, \$6.50

\section{SNOW WEIGELIA, Weigelia candida}

A fine, vigorous shrub with white flowers in June. Keep it toward the back of the shrubbery.

$$
\text { Height, 2-3 ft.; Each, \$ .75; Ten, \$6.50 }
$$

\section{EVA RATHKE WEIGELIA}

This has crimson flowers that cover the whole plant.

$$
\text { Height, 2-3 ft.; Each, \$ .75; Ten, \$6.50 }
$$

\section{PINK WEIGELIA, Weigelia rosea}

Big shrub growing six feet high with pink bells in May and June.

Height, 2-3 ft.; Each, \$ .75; Ten, $\$ 6.50$

\section{YELLOWROOT, Xanthorhiza}

A mat of yellow roots like quack grass and grows about two feet high, has good foliage and inconspicuous flowers; native in shady woods; valuable at the edge of the shrubbery.

Height, 1-11/2 ft.; Each, \$ .30; Ten, $\$ 2.50$ 


\section{VINES}

T INES are nature's lace. They decorate the thicket, fence, bank, hillside and brookside. You can add vines where there is not room for a tree or shrub. Carpeting the ground is a new use for vines that is not only beautiful but often more economical than grass, for when established they almost crowd out the weeds. The expense need not be great for the free use of vines. Nany of them can be planted all summer for they are available in pots or they can be cut back and will sprout out again. (For Climbing Roses see page 63.)

Come to the nursery, talk over your problems and see where vines will aid.

\section{BOWER ACTINIDIA, Actinidia arguta}

A vine as big as Wisteria, heavily laden with sweet edible Gooseberry-like fruits. The flowers are large, white and fragrant like the Orange Blossom.

Each, $\$ .75 ;$ Ten, $\$ 6.50$

\section{VIRGINIA CREEPER, Ampelopsis quinquefolia}

The five-fingered plant that you have seen holding the sand dunes, turning tall trees to pillars of fire or waving red banners from the top of evergreens.

Height, 2-3 ft.; Each, $\$ .50$; Ten, $\$ 4.50$

\section{JAPANESE CREEPER, Ampelopsis tricuspidata veitchi (Japanese Ivy)}

A vine with three pointed or three parted leaves which will cling to brick walls.

Height, 1 ft.; Age, 1 year; Each, $\$ .30 ;$ Ten, $\$ 2.50$

\section{SWEET AUTUMN CLEMATIS, Clematis paniculata}

A bank of these are like a snowdrift in August and September. With thousands available, plant the hill or steep bank, plant them to tumble over trees and shrubs at the border of the woods, over a tennis backstop, to change the old fence into a thing of beauty or give a picturesque touch to your garage; pleasing all with their spicy fragrance.

$$
\text { Age, } 2 \text { years; Each, \$ .50; Ten, } \$ 4.50
$$

\section{AMERICAN BITTERSWEET, Celastrus scandens}

A familiar vine spiraling up tall trees, with clusters of red and orange fruit.

$$
\text { Each, } \$ .75 ; \text { Ten, } \$ 6.50
$$

WINTERCREEPER, Evergreen bittersweet or Euonymus. (See page 47)

These are not used one per cent as much as they should be. They will run up the tall trees, branching out with long festoons of red berries and bright green leaves. You can transform your woodland into a bower of beauty for winter. We will map out a list of places for you to see where this has been done. You can plant them along the walls and make them as beautiful as walls can be. To carpet the ground in the woods, at the border of an evergreen group, at the foundation of your house they are beautiful and economical. You can plant them all summer. The small plants are very cheap.

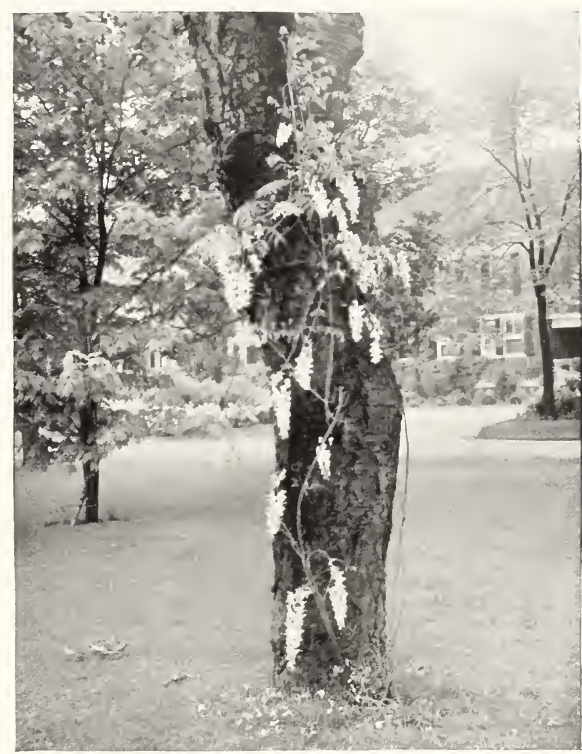

Chinese Wisteria. You can decorate the tallest trees. Wisteria like its relatives Clover, Alfalfa and Locust feeds itself from the nitrogen in the air and thrives on the poorest soil

\section{ENGLISH IVY, Hedera helix}

A favorite vine especially suitable for shady places on the north sides of the walls, in the woods or for carpeting the ground.

$$
\text { Each, \$ .60; Ten, \$5.50 }
$$

\section{WINTER JASMINE, Jasminum nudiflorum}

More like a fountain of gold stars than a vine. Plant it on the south side of the building and in the winter after ten days of warm weather it will hang out its golden stars of Forsy thia-like flowers.

$$
\text { Height, 2-3 ft.; Each, \$ .75; Ten, \$6.50 }
$$

HALL JAPANESE HONEYSUCKLE, Lonicera japonica halliana

White flowers in June and again in autumn, black berries all winter, the foliage green until mid-winter. Use it in quantity for banks and fences, also as ground cover.

Height, 2 ft.; Each, $\$$.75; Ten, $\$ 6.50$ 


\section{HALL VARIEGATED HONEYSUCKLE}

A change in color is welcome in small gardens and even in large ones where a bit of surprise will do no harm. This is bright golden yellow.

$$
\text { Each, } \$ .75 ; \text { Ten, } \$ 6.50
$$

\section{HENRY HONEYSUCKLE, Lonicera henryi}

A new Honeysuckle described by the Arnold Arboretum as the hardiest evergreen vine in New England. The leaves stay bright all winter.

$$
\text { Each, \$ .75; Ten, } \$ 6.50
$$

\section{CHINA FLEECEVINE, Polygonum auberti}

A new vine related to Smartweed, with festoons of white similar to Clematis.

$$
\text { Each, \$ .75; Ten, } \$ 6.50
$$

\section{KUDZU BEAN, Pueraria thunbergiania}

A gigantic Lima Bean growing forty feet a year with fragrant flowers.

$$
\text { Each, } \$ .75 ; \text { Ten, } \$ 6.50
$$

BIGNONIA RADICANS, Tecoma radicans, or trumpet creeper

Native in Maryland and southward. Climbing the tallest trees, festooning them with scarlet trumpets in mid-summer.

$$
\text { Height, 1/2/2-2 ft.; Each, \$ .75; Ten, \$6.50 }
$$

PORCELAIN AMPELOPSIS, Ampelopsis heterophylla or Vit is heterophylla

A grapelike vine with light blue berries, a rare and beautiful color.

$$
\text { Each, } \$ .75 ; \text { Ten, } \$ 6.50
$$

\section{LONGCLUSTER WISTERIA, Wisteria multijuga}

Seedlings of Japanese Wisteria, festooning the bridges, etc. in clusters three feet long.

$$
\text { Each, } \$ .75 ; \text { Ten, } \$ 6.50
$$

\section{CHINESE WISTERIA, Wisteria sinensis}

The old favorite that climbed the tops of the tallest trees, festooning them with fragrant blue flowers in early May.

Each, \$ .75; Ten, $\$ 6.50$

\section{NEW AND RARE PLANTS}

T $\mathrm{T}$ is impractical to catalogue the species, varieties and sizes grown by a nursery that has been carefully experimenting for your benefit since 1853. Professor Sargent, head of the Arnold Arboretum says, "It takes seventy-five years to test a tree." Each of these seventy-five year tests indicates a degree of unhappiness, slow growth, lack of beauty, cheerfulness or profit. It will affect you within five, ten or fifteen years. You cannot be cynical and say you do not care so long as the tree looks well while young. We have tested almost every species we thought valuable.

When studying the development of your place, don't confine yourself to reading books and catalogues, go where you can see the plants. You will enjoy riding and walking through Hicks Nurseries. Most of the plants are labeled. You can see whether they like it or not, and decide what you should plant. You can find a host of plants not in the catalogue and enjoy the discovery.

To find a place is easier if you have seen them, therefore we repeat the invitation to come to the nursery, roam around, find what you like, see a salesman and take it home with you.

"Adventures in My Garden and Rock Garden" by Louise Beebe Wilder, illustrated by Miss Winegar, Doubleday Page and Company, \$5.00.

“The Cultivated Evergreens" edited by L. H. Bailey, MacMillan Company, \$7.50. Henry Hicks is author of one chapter.

The fun of rare plants collecting is described in the March, '24 "Atlantic Monthly" by Mr. Geo. P. Brett, president of MacMillan Company.

"The Garden Magazine," Garden City, L. I.; "Bulletin of Popular Information," Arnold Arboretum, Jamaica Plains, Mass.; "Horticulture," Massachusetts Agricultural Society, Boston; these will aid you to keep up with the rare and new plants. We will help you get acquainted with other literature, botanic gardens and private collections and show you how to get into the game. 


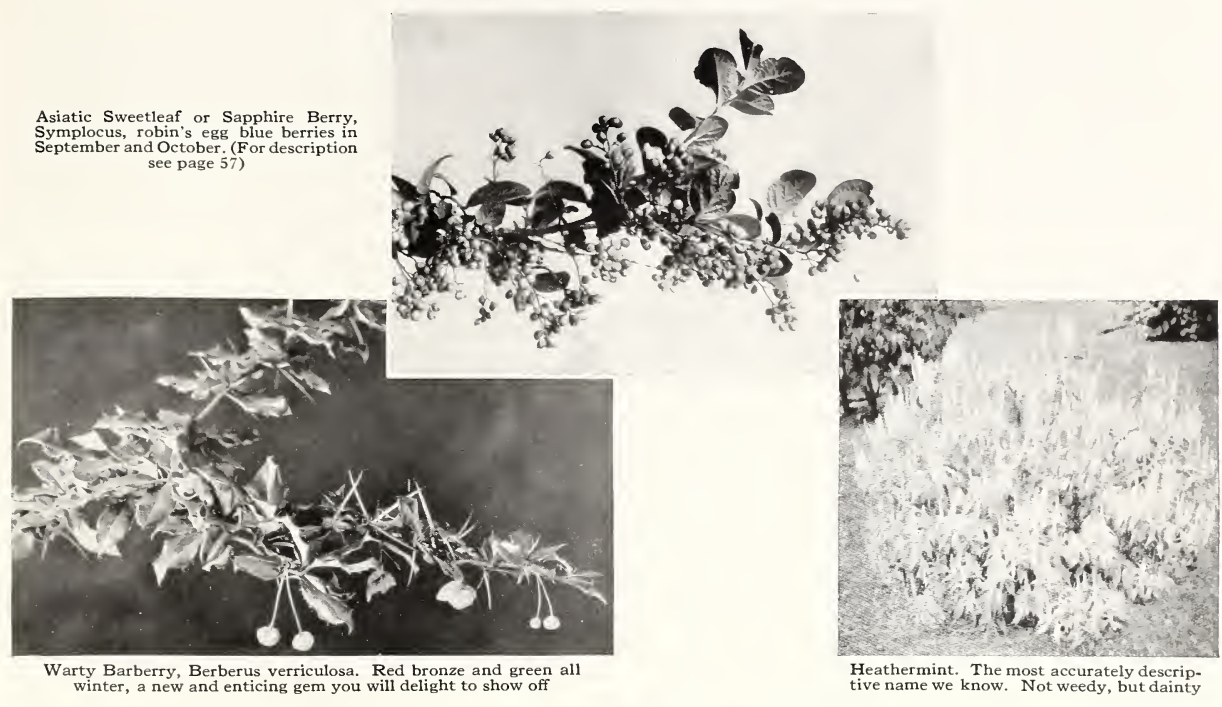

\section{DUNBAR'S DOGWOOD, Cornus Dunbari}

A Coral Dogwood named for John Dunbar, superintendent of Highland Park, Rochester, one of the foremost introducers of valuable plants, who has built up an arboretum only exceeded by Arnold Arboretum.

$$
\text { Height, 5-6 ft.; Each, } \$ 3.00
$$

\section{LITTLELEAF DOGWOOD, Cornus paucinervis}

Similar to the Coral Dogwood, but darker red.

Height, 3 ft.; Each, $\$ 1.00$

\section{TREE HAZEL, Corylus colurna}

We raised our plants from a tree in Highland Park twenty-five feet high, one foot in diameter. The nuts are an important food product and are shipped in quantity from the south shore of the Black Sea.

$$
\text { Height, } 2 \text { ft.; Each, } \$ 1.50
$$

\section{PEKING COTONEASTER, Cotoneaster acutifolia}

This eventually becomes a slender bush twelve feet high having black fruit.

$$
\text { Each, } \$ 1.50
$$

\section{DIELS COTONEASTER, Cotoneaster dielsiana}

This has showy bright red fruit.

$$
\text { Height, } 2 \mathrm{ft} \text {; Each, } \$ 1.50
$$

\section{SPREADING COTONEASTER, Cotoneaster divaricata}

This has the most showy, glossy, dark green leaves, turning bright scarlet in fall; bright red berries all winter.

Height, 2-3 ft.; Each, $\$ 1.00$
FRANCHET COTONEASTER, Cotoneaster francheti

A densely branched spreading shrub with orange-red fruit.

Height, 11/2 ft.; Each, \$1.50

\section{ZABELS COTONEASTER}

This is the handsomest of the Cotoneasters; graceful, drooping habit, silky leaves and having abundant dark red fruits.

Height, 2 ft.; Each, $\$ 1.50$

\section{HEATHER MINT, Elscholtzia stauntoni}

A plant of the mint family, two feet high, with showy lavender-purple flowers in late summer. Add it to your flower garden, the bees like it and you will like its perfume.

$$
\text { Age, } 2 \text { years; Each, } \$ 1.00
$$

\section{REDVEIN ENKIANTHUS, Enkianthus campanulatus}

It resembles its relative the Highbush Blueberry in size and brilliant autumn foliage. It has pink bells in May like the Andromeda.

$$
\text { Height, 1-2 ft.; Each, \$1.25 }
$$

\section{EVODIA HUPEHENSE}

Belongs to the Toothache Tree family. One of the smallgrowing flowering trees recently introduced from Northern China. Yellowish white flowers.

$$
\text { Height, } 4 \mathrm{ft} \text {; Each, \$1.50 }
$$

SHOWY BORDER FORSYTHIA, Forsythia intermedia spectabilis

An improvement, if that is possible, on its parent Fortune Forsythia.

Height, 3 ft.; Each, $\$ 1.00$ 


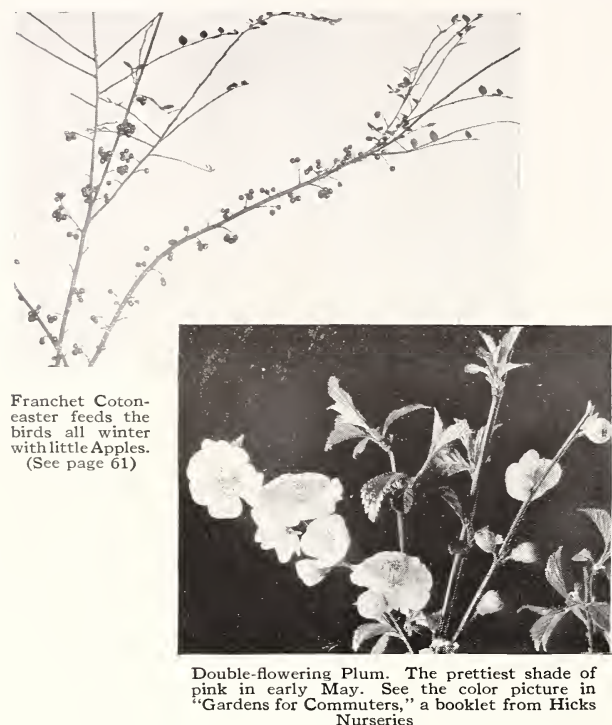
Nurseries

\section{MOUNTAIN SILVERBELL, Helesia monticola}

Recently discovered. Grows eighty feet high. Flowers like snowdrops.

Height, 3-t ft.; Each, $\$ 3.00$

\section{CHINESE WITCH-HAZEL, Hamamelis mollis}

You know the Witch-hazel in December. This blooms in February with the Japanese Pussy Willow, Jasmine and fragrant Honeysuckle, but is more certain. Start a winter garden and contradict those who say the country is dull in the winter.

$$
\text { Height, } 1 \frac{1}{2} \mathrm{ft} \text {; Each, \$2.50 }
$$

STANDISH HONEYSUCKLE, Lonicera standishi

Fragrant yellow blossoms sometimes covered by ice in early spring.

$$
\text { Height, 2-3 ft.; Each, \$ .75 }
$$

\section{ARNOLD CRAB-APPLE, Malus arnoldiana}

A dwarf Apple soon becoming six feet high and eight feet broad, thickly hung with white blossoms and cherrylike fruit as good as cider when frozen and welcome to the birds.

$$
\text { Height, 4-5 ft.; Each, \$1.50 }
$$

\section{ACID MULBERRY, Morus acidosa}

A broad bush with acid fruit.

$$
\text { Height, 3-t ft.; Each, } \$ 1.00
$$

\section{FATHER HUGO'S ROSE, (Golden Rose of China) Rosa Hugonis}

Named for Father Hugo who discovered it in China. See illustration in Bacon Garden, page 8 . A mound of gold at Lilac time, long before other roses.

Height, 21/2 ft.; Each, \$2.50

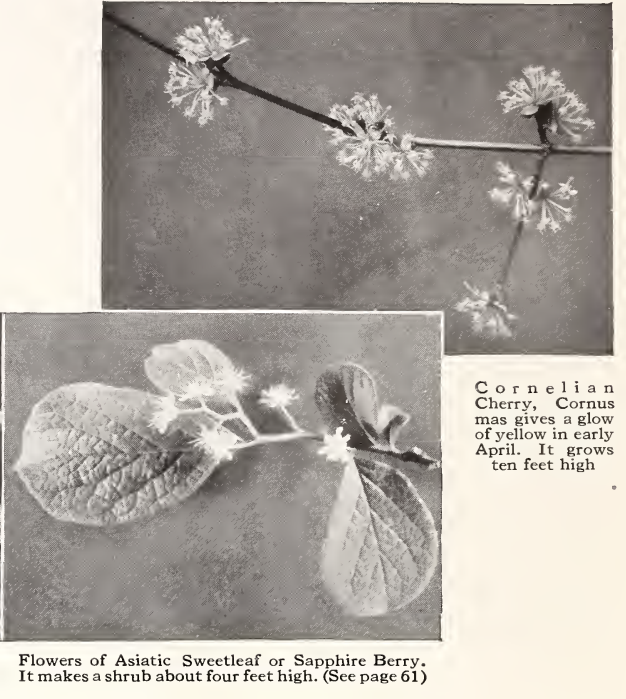

LILAC, Syringa

Named varieties. Ask for list.

Height, $2-3 \mathrm{ft}$.; Each, \$1.50

CHENGTU LILAC, Syringa sweginzowi

Pink. Each, \$1.50.

FELTY LILAC, Syringa tomentella

Pink. Each, \$I.50.

NODDING LILAC, Syringa reflexa

All other lilacs have upright panicles, these hang gracefully down. Each, \$I.5c.

WOLF LILAC, Syringa wolfi

One of the newer varieties from Korea, having long pointed dull green leaves and large clusters of violet purple flowers. Late blooming. Each, \$I.50.

CHAMAEDRYS GERMANDER, Teucrium chamaedrys

Cover plant, edge plant or rock garden plant. A cushion of deep green little leaves about six inches high. Pink flowers in early summer. They are in pots so that you can plant them any time.

Height, 3-in. pots; Each, \$ .50; Ten, \$4.50

\section{WRIGHT VIBURNUM, Viburnum wrighti}

Similar to the Japanese Bush Cranberry, with bright red berries all winter. Named for the botanist of the Perry Expedition, which opened commerce and diplomatic relations with Japan.

Height, 2 ft.; Each, $\$ 2.00$ 


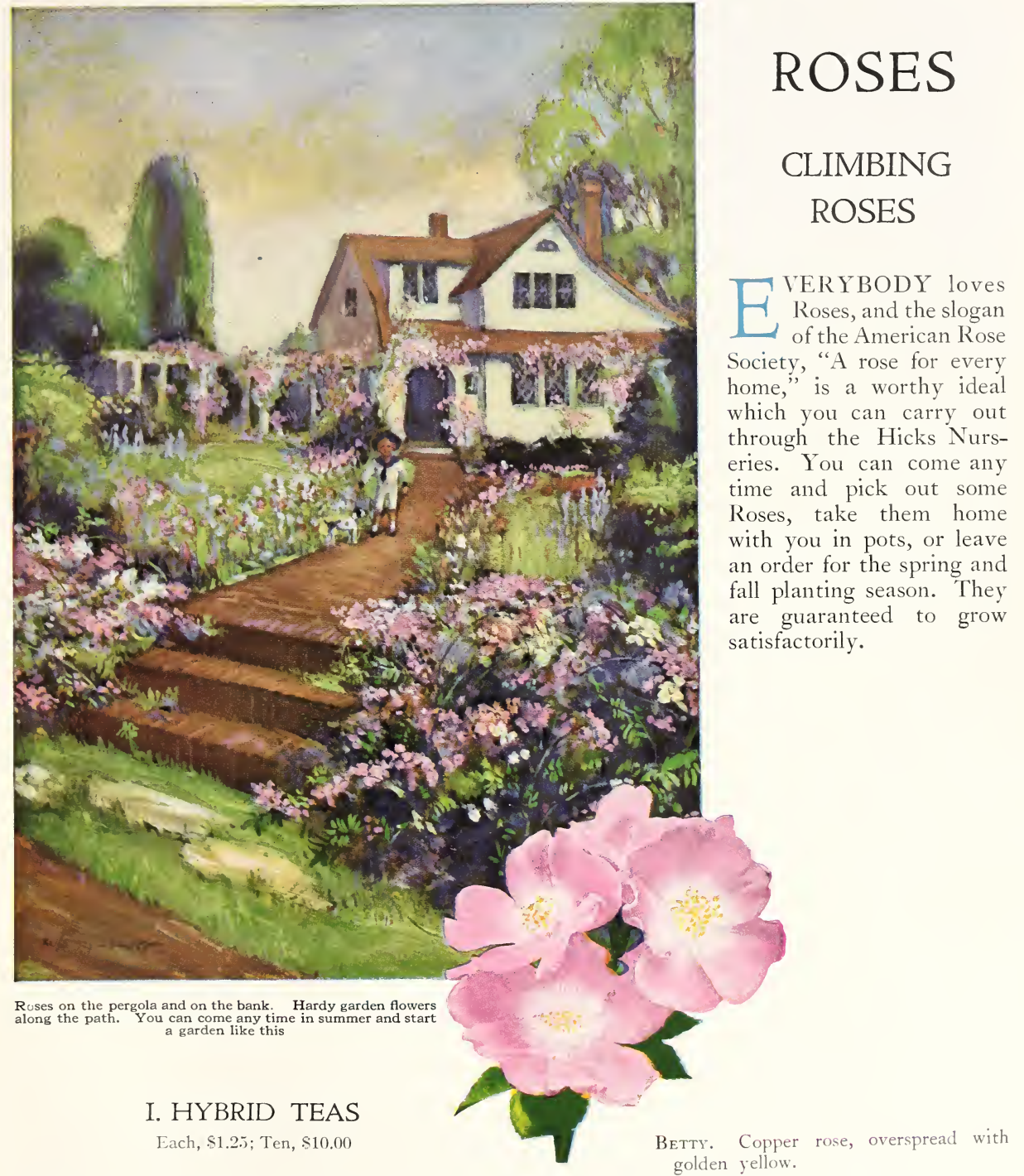

Similar to the kinds you buy from the greenhouse. They bloom all summer. Protect them during the winter by mounding up the plants one foot high; after freezing, mulch with strawy manure or leaves to keep frozen. Enrich the ground either with bone-meal or manure and hoe thoroughly. They like clay soil, but that is scarce on Long Island, so make up with bone-meal, manure, hoeing and water.
Chateau de Clos Volgeot. Deep, soft, velvety scarlet flowers.

DeAn Hole. Silvery carmine, shaded salmon.

Dorothy Page Roberts. Coppery pink, suffused apricot-yellow.

Duchess of Wellington. Semi-double, saffron-yellow flowers, stained with crimson, changing to lighter yellow. 


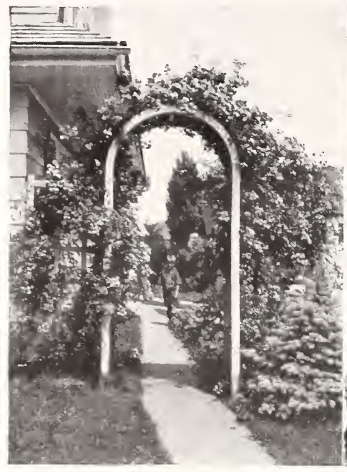

An arch of climbing roses. There is often room for a touch of beauty like this even on a narrow lot

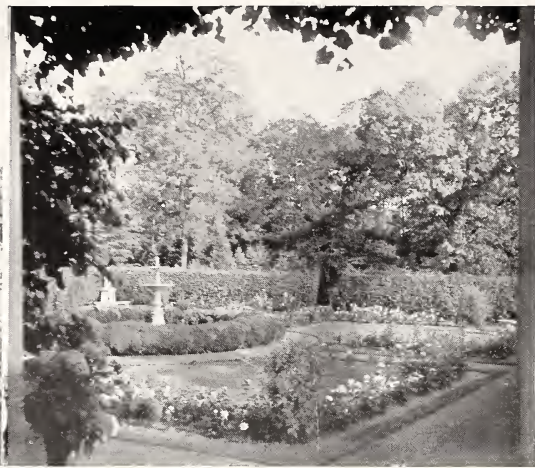

A rose garden on Long Island, bordered with box and hedged with hemlock. Leave plenty of space between the roses and surrounding shrubbery so that the shrubs cannot stretch their roots into the beds and steal the roses' food

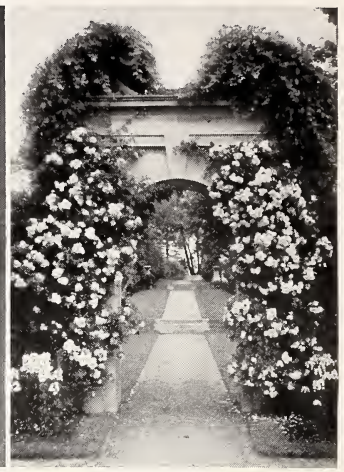

An arch of Dorothy Perkins roses in the walled garden on the estate of Mr. John S. Phipps, Westbury
Gruss an Teplitz. Clear crimson-scarlet flowers.

HadLEY. Bright red flowers.

Harry Kirk. Clear yellow.

Kaiserin Augusta Victoria. Creamy white, shading to delicate primrose.

Lady Alice Stanley. Deep coral-rose on outside of petals, pale flesh on inside.

Lady Ashtown. Pale, carmine-pink shading to golden yellow.

Lady Hillingdon. Clear apricot-yellow.

Madame Butterfly. Brilliant pink, suffused apricot and gold.

Marie Van Houtte. Clear yellow, petals tipped rose color.

Molly S. Crawford. Pure white.

Juliet. Outside petals old-gold, and inside vary from scarlet to crimson.

Los Angeles. Flame-pink, toned with coral, shaded yellow at base.

Mme. Edouard Herriot. Coral-red, shaded yellow to scarlet.

\section{HYBRID PERPETUALS}

Each, $\$ 1.25$; Ten, $\$ 10.00$

These bear big, double Roses and grow into bushes three feet high. They bloom freely in June.

Beaute de Lyon. Coral-red, slightly shaded with yellow. Frau Karl Druschisi. Large white.

Other varieties are in stock or we will get them for you.

\section{CLIMBING ROSES}

\section{Each, $\$ .75 ;$ Ten, $\$ 6.00$}

These are particularly happy on Long Island, as much at home there as their relative, the Running Blackberry; covering sandy fields, climbing over trees or buildings.

They make a good hedge when trained on a fence. Their use for tennis back-stops and poultry-yard fences is well known. A Rose garden or flower garden is frequently surrounded by a pergola decorated with climbing Roses. Climbing Roses need not climb; if left alone they make most effective shrubs. They are frequently used on pillars, and can be transformed into standard Roses by staking up one stem.

Climbing American Beauty. Flowers rich carmine, large and fragrant. A vigorous grower.

American Pillar. Cherry-pink with white center, forming a lovely contrast with the golden stamens.

Dorothy Perkins, Pink. Perhaps the most popular of all Climbing Roses. Makes a strong growth and produces blooms in greatest profusion. The flowers are light pink in color, fragrant, and very double in form.

Dorothy Perkins, White. With the exception of the white flowers, the same as the preceding variety. Makes a lovely contrast when planted with the pink sort.

DR. W. VAN FLEET. A splendid pink Rose, with a pointed bud, opening into a double flower. Makes a strong growth, and has splendid foliage.

Excelsa. Almost a glorified Crimson Rambler; the foliage dark, glossy green and entirely free from mildew. The flowers are carried in large trusses of the most brilliant scarlet-crimson imaginable.

Roserie. Similar to standard Tausendschon in form, thornless plant and habit of growth, but having blooms of an even shade of deep pink or carmine in its cupped flowers. A rose that is worth more attention than it has yet had.

Paul's Scarlet Climber. The most brilliant Rose of any class, because of its clear, vivid shining scarlet in large, semi-double flowers which remain unusually long and in good condition on the plants.

Rosa Wichuraiana. A trailing Rose from China, with creamy white flowers and golden stamens. The leaves are small and glossy, and make an impenetrable mat about one foot deep. Dry, sandy ground does not prevent its making good growth, and therefore it can be used on the pine barrens and on the sand-dunes.

\section{MISCELLANEOUS ROSES}

\section{Each, $\$ 1.25 ;$ Ten, $\$ 10.00$}

Conrad F. Meyer. H. Rug. Clear, bright silvery rose. Persian Yellow. AB. Yellow. 


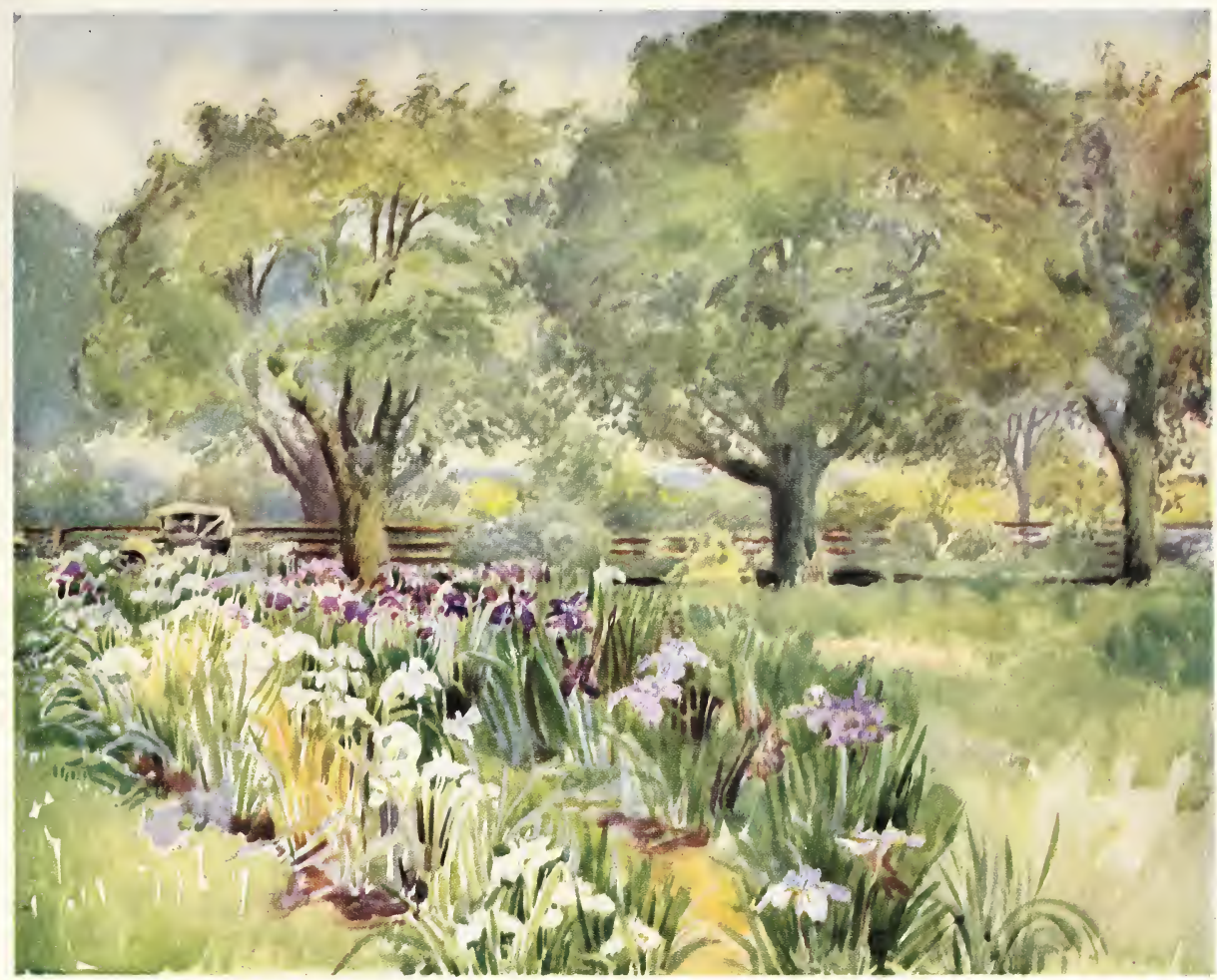

Japanese Iris at Hicks Nurseries. Come and pick them out in bloom, take them up with a shovelful of dirt. They pay you immediately and the clumps get bigger and bigger every year. To describe the colors is almost impossible white, blue, pink and purple. You can make a sheet of color like this on your place, or along a stream or pond for the public benefit. From a painting by Mrs. Pennypacker

\section{HARDY GARDEN FLOWERS}

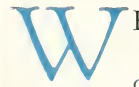

HY do you grow flowers? Because you love color and fragrance.

To help you get the most color, arranged in the most beautiful way, is the object of this Department.

How grow flowers?

Take any bit of ground, dig in decayed leaves or other decaying vegetable matter, as grass, weeds, salt hay, or manure; add wood ashes or commercial fertilizers. Select your favorite plants from this catalogue, or, better, call at the nursery and get them. When you plant them, space them from 8 inches to 2 feet apart.

We believe it is not an exaggeration to say that you can come to the Hicks Nurseries and get a garden that is nearly perfection.

Plants from Hicks Nurseries are guaranteed to grow satisfactorily, or we replace them free. We hope you will report to us your success or failure, so we can pass on the knowledge.

In planning out your flower-borders, make them wide. Mr. Walter Parish, superintendent of the Hardy Garden Flower Department, Hicks Nurseries, says, "People make a mistake in planting little narrow borders three to four feet wide. They cannot get a sweep of color, and after one thing is out of bloom, there is not enough room for other plants. Make the borders eight feet wide." Plant ten, twenty, or fifty of a kind, if you have room. 


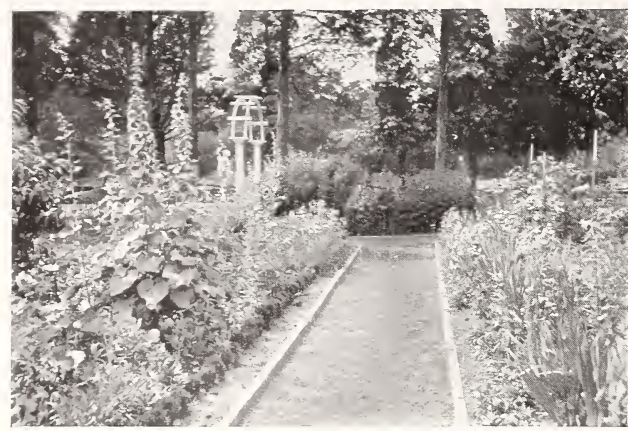

Garden of Mrs. Warren, Halesite, L. I. The background of old Cedar trees sets off the Hollyhocks, Foxglove and Iris. Many gardens need a frame or setting of trees or hedges

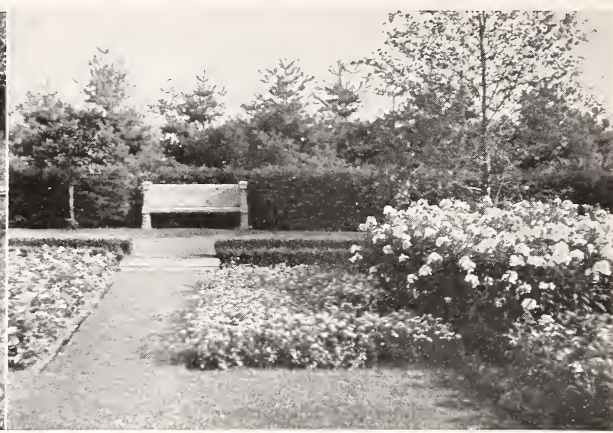

Garden of Mr. Sterling Postey, East Norwich. Back of the hedge Hicks Nurseries planted a border of tall Pines for a screen to the entrance drive. The flowers on the right are white Phlox

Naturalizing or planting among the grass and shrubs is an art but little developed in this country. Mr. Wm. Robinson, author of "The English Flower-Garden," has clearly set forth the principles for this type of gardening. It is based on matching plants and situations so that nature does most of the work. The plants take care of themselves. (See pages 2-9.)

\section{YARROW, Achillea, the Pearl}

The rather small, double white flowers, resembling those of the Bridal Wreath, are borne all summer, in fine clusters on long stems and are excellent for cutting. Grows one and one-half feet high.

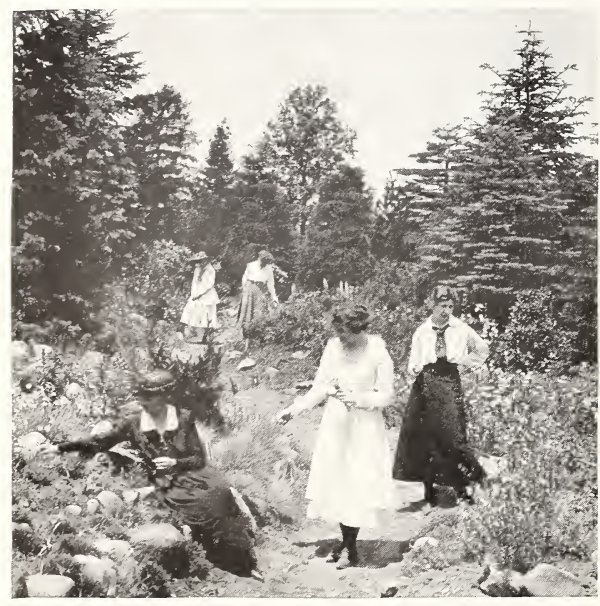

The Rock Garden at Hicks Nurseries. Many people like to stroll through because it is quiet and shut off from the noise of the public highway and other activities. The border of evergreens on the right was moved in mid summer and then the stones were placed, helping to keep the soil cool and moist. Roots go down between the stones and do not compete with
weeds. You can come to Hicks Nurseries and get plants for your rock weeds. You can come to Hicks Nurseries and get
garden any time of the year

\section{HOLLYHOCK, Althaea}

Its stately spires, six feet high, include white, clear pink, salmon, scarlet, and blackish-maroon and are borne in July.

\section{Double}

The flowers of the double Hollyhocks are like paper rosettes. They are charming in the walled garden.

\section{Single}

Nothing surpasses the old-fashioned single Hollyhock.

\section{GOLDENTUFT, Alyssum saxatile}

These look like little mounds of gold when in bloom in April and May. Used for bordering with Iris pumila and white or lilac Moss Pink.

\section{DROPMORE BUGLOSS, Anchusa dropmore opal}

A flower that ranks with the Delphinium for producing tall masses of blue. It will continue to bloom from June to September if not permitted to go to seed and is fine for the back of the border. Grows three to five feet high.

\section{ITALIAN BUGLOSS, Anchusa italica}

The same as preceding, except in color, which is a lighter shade of blue. Use some of each.

\section{YELLOW CAMOMILE, Anthemis tinctoria}

A compact bushy plant, covered with yellow flowers throughout the summer. It will do well in poor soils.

\section{COLORADO COLUMBINE, Aquilegia caerulea}

Large blue and white flowers. Aquilegias seem to thrive in either sun or shade. If you have a woodland path, give them a trial.

\section{GOLDEN COLUMBINE, Aquilegia chrysanthea}

A yellow variety with long spurs. The drop of honey at the tip feeds the hummingbirds on their way from the tropics in May. 


\section{PLANTAIN THRIFT, Armeria plantaginea}

A grass-like plant, suitable for bordering paths. Thrives at the seaside; also good for the rock-garden. Bright red flowers.

\section{CLIMAX ASTER, Aster climax}

One of the most desirable on account of the large lavender flowers. Grows three to four feet high and blooms in August and September.

\section{GLORY OF NANCY, Aster Glorie de Nancy}

Soft pink, single flowers, quite similar to St. Egwin.

ASTER, Rosy New England, Aster novae-angliae roseus

A hybrid of our wild Asters. Large, single deep rose flowers.

\section{ASTER, ST. EGWIN, Aster St. Egwin}

Dwarf pink-flowered variety. Plant in front of taller growing kinds.

\section{TATARIAN ASTER, Aster tataricus}

Stems six feet high, bearing azure-blue flowers in October. The latest showy flower.

\section{BLUE WILD-INDIGO, Baptisia austrilis}

Rather a bushy plant and very showy, with its long racemes of sweet-pea-shaped indigo-blue flowers. Blooms in June and July and grows three to four feet high.

\section{ENGLISH DAISY, Bellis perennis, white and pink}

The dainty English Daisy can fill a niche in every garden. Pink and white flowers in May.

\section{WHITE BOLTONIA, Boltonia asteroides}

Small, daisylike flowers throughout the summer. Grows four to five feet. Fine for natural plantings or wild gardens.

\section{DWARF PINKRAY, Boltonia latisquama nana}

Compact, aster-like blossoms through the summer and autumn. Grows two feet high.

\section{CARPATHIAN BELLFLOWER, Campanula carpatica}

Dense tufts of leaves from which numerous, broad blue, salver-shaped flowers are thrown up singly on wiry stems about eight inches high. A splendid plant for bordering beds.

CANTERBURY BELLS, Campanula medium, pink, white and blue

The best-known of all the Campanulas, and its magnificent spikes of blue, pink and white flowers produce an effect in the garden not equaled with any other plant. Requires extra winter protection.

PEACHLEAF BELLFLOWER, Campanula persicifolia, white and blue

This is one of the best of the Bellflowers. It grows two to three feet high, with large blue or white bells, in spikes, in June and July.

\section{CHIMNEY BELLFLOWER, Campanula pyramidalis, blue}

This is the showiest and tallest of the Campanulas, growing + to 6 feet high. Needs protection here in winter.

\section{SNOW-IN-SUMMER, Cerastium tomentosum}

A low-growing plant, with silvery gray foliage. Good for carpeting or bordering. Use it freely in the rock-garden. White flowers in June and July.

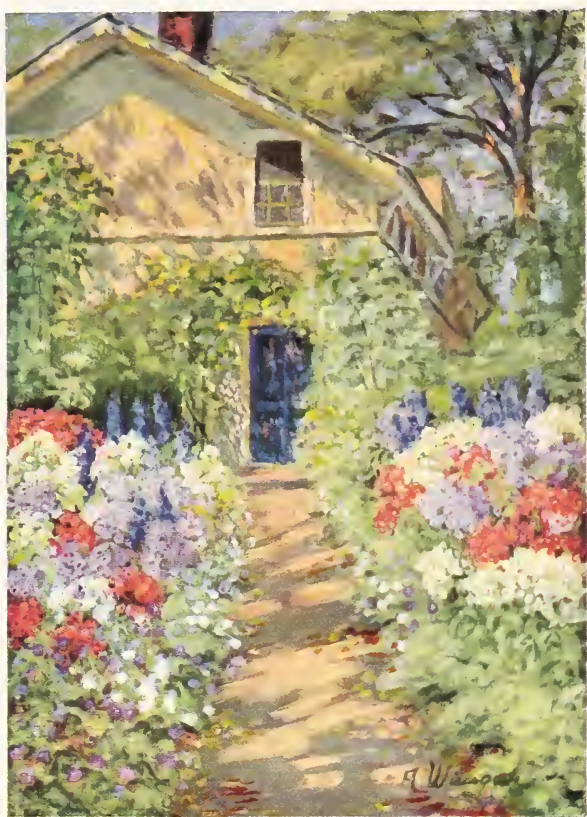

Painted for Hicks Nurseries by Miss Winegar, showing her garden a Bronxville, N. Y. The house is a remodelled barn. The pink and white Phlox contrast with the blue spikes of Delphinium or Larkspur. This is a view in mid-summer. In spring it is bright with Tulip and Spirea. (See page 70 for the fall)

\section{PINK TURTLEHEAD, Chelone Iyoni}

A poor name for a good plant. A native of the Virginia mountains, the Turtlehead thrives in moist, shady spots. Deep pink flowers.

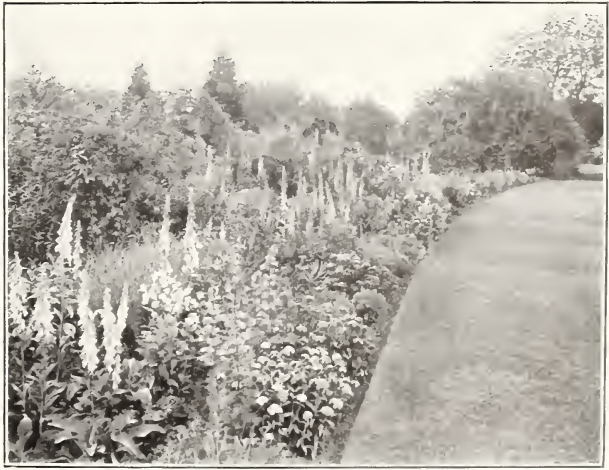

Almost anyon? can have a border like this; tall Foxglove in the back. Canterbury Bells in the middle, Sweet William and lower things at the edge. Come to Hicks Nurseries and get something which is comin used in the best gardens. You can use Hicks Nurseries as a source of supply for renewing your garden 


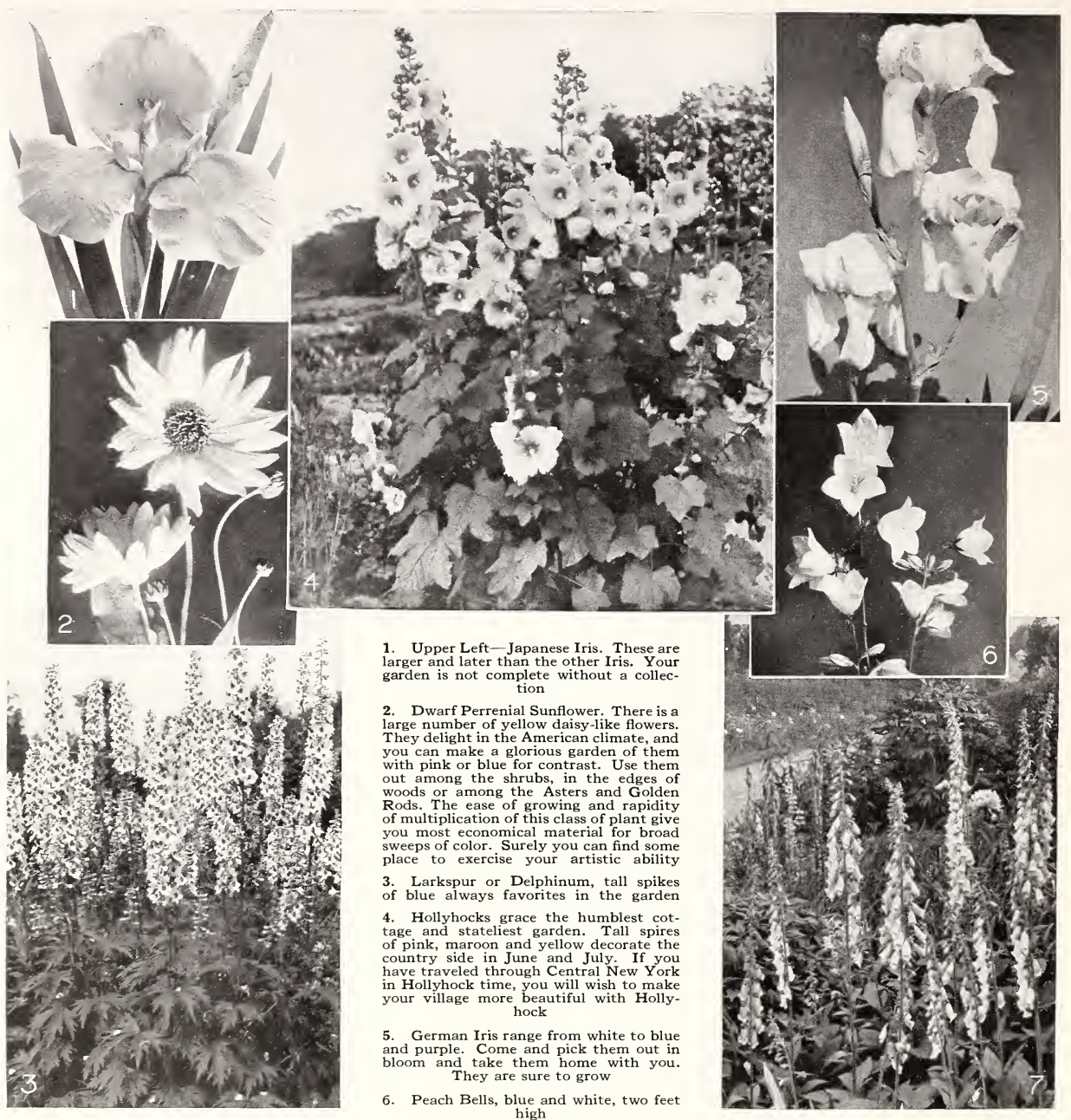

7. Foxgloves are pink and white

\section{CHRYSANTHEMUMS, Chrysanthemums pompon}

The Chrysanthemum is one of the standbys for a fine show of flowers from early October to frost. The flowers vary from one to three inches. To get good results, come to the nursery in summer and early autumn and pick out plants just coming into bloom to replenish your garden. The Long Island season, with late frost, favors them.

$\begin{array}{lll}\text { BRONZE } & \text { RED } & \text { YELLOW } \\ \text { WHITE } & \text { PINK } & \end{array}$

\section{LILY-OF-THE-VALLEY, Convallaria majalis}

This, with the Bleeding-heart and Hollyhock, is always associated with old-fashioned flower-gardens. Nothing has ever surpassed it in delicate fragrance.

\section{LANCE COREOPSIS, Coreopsis lanceolata}

Brilliant yellow flowers on long, slender stems about two feet high. It blooms all summer, and is superior in delicacy and grace to many of the yellow flowers. 
BELLADONNA LARKSPUR, Delphinium belladonna

With many garden enthusiasts, if a flower is blue, it needs no further recommendation. The Larkspur is a universal favorite. This variety is that exquisite light blue so much esteemed and so seldom encountered. Blooms through the summer.

\section{LARKSPUR, Delphinium Gold Medal Hybrid}

Grown from selected seed and bound to produce strong, handsome flower-spikes.

\section{SIBERIAN LARKSPUR, Delphinium grandiflorum}

Slender stems, two to three feet high. Flowers vary from blue to white, with long, tapering spurs. A favorite.

\section{SWEET WILLIAM, Dianthus barbatus}

Nothing will yield a more solid mass of color in June than this. It is old and popular. If you want a carpet of pretty salmon-pink or scarlet, or a sheet of pure white or crimson, this should be your selection.

\section{FOXGLOVE, Digitalis}

The tall, dignified spikes of the Foxglove, with heavily spotted throat of the individual pink, white and yellow blooms, are always charming. Valuable in the border or can be planted freely along the wood edge. They bloom in June.

\section{LOW GLOBETHISTLE, Echinops humilis}

Globular heads of deep metallic blue flowers make this a showy and interesting plant. They should be massed against the coarser-growing plants, like Helianthus.

\section{MISTFLOWER, Eupatorium ceolestinum}

Toward the middle of September this is an unbroken sheet of light blue. The flowers are like tufts of blue moss, and the long stems make it excellent for vases. Grows fifteen inches high. Also called Hardy Ageratum.

\section{AMETHYST ERYGO, Eryngium amethystinum}

You have probably seen the Teasel with its prickly stem and head. Here is something similar but with a blue flower and steel-blue stem.

\section{BLUE PLANTAIN LILY, Hosta caerulea, Funkia caerulea}

The Day Lilies improve with age, producing more of their lovely deep blue bell-shaped flowers every year.

FORTUNE PLANTAIN LILY, Hosta fortunei, Funkia fortunei

Pale lilac flowers. One of the best of the Day Lilies.

PLANTAIN LILY, Hosta, Funkia media picta

Similar to above but with light lavender flowers.

\section{PLANTAIN LILY, Hosta, Funkia ovata}

Grows two feet high and produces its blue flowers in June and July. Thrives in the shade.

\section{BIG PLANTAIN LILY, Hosta plantaginea grandiflora (Funkia subcordata)}

No flower gives the impression of greater purity. The delicate orange perfume of these long, waxy white lilies pervades the garden in August.
COMMON PERENNIAL GAILLARDIA, Gaillardia artistata (grandiflora)

Probably nothing is better for continuous blooming from June I. It grows two feet high. The daisy-like flowers are a gorgeous combination of orange and crimson and are excellent for cutting.

\section{BABYSBREATH, Gypsophilla paniculata}

Pleasing for its extremely delicate foliage, thickly set with tiny white flowers. Can be used advantageously in arranging bouquets.

\section{COMMON SNEEZEWEED, (Riverton Gem) Helenium} autumnale

Orange-bronze, daisy-like flowers resembling the single Chrysanthemum. Grows three to four feet high and blooms in August and September.

\section{GREAT SNEEZEWEED, Helenium autumnale super- bum}

The daisy-like flowers of yellow and orange, with yellow disc, are produced all summer. Fine for cutting. Grows one foot high.

\section{PITCHER HELIOPSIS, Heliopsis helianthoides pitch- eriana}

A small-growing Sunflower that thrives without any care, even in 'dry soil.

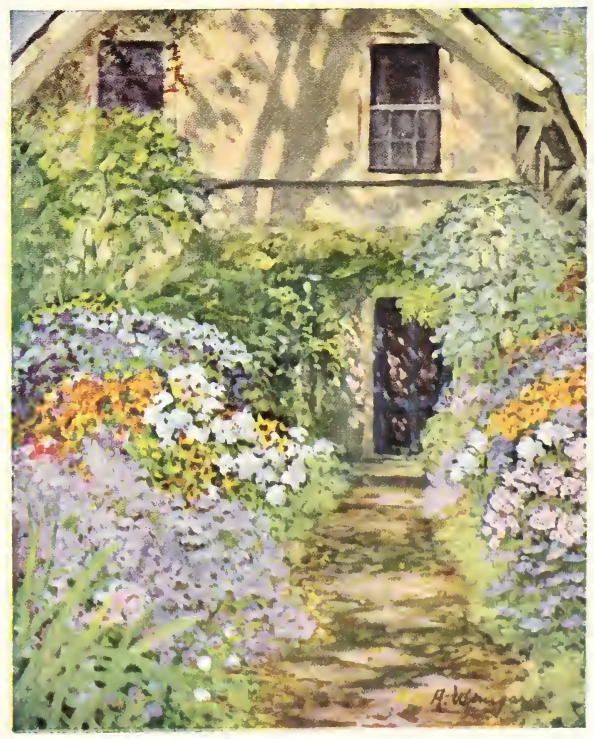

Miss Winegar's fall garden; between spring and summer these flowers have been waiting. Light blue is Aster; dark purple is the New England Aster; the orange is Sneeze Weed-Riverton Gem. The pink in the right foreground is Japanese Anemone 


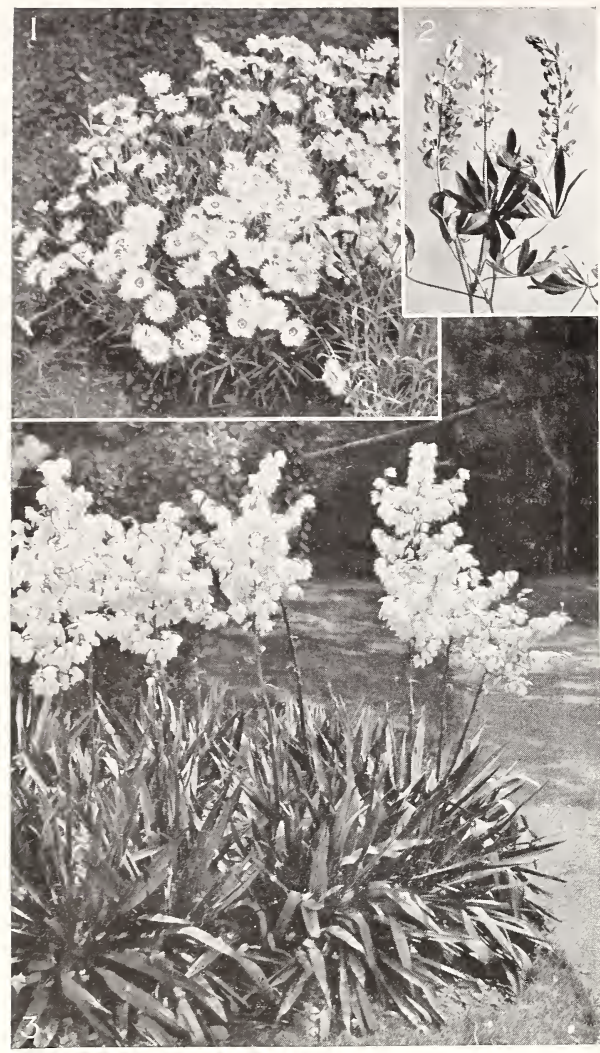

1. Pink. This carnation-like flower makes sweeps of color along a border or on a dry bank

2. Lupin, spikes of blue, pea shaped flowers. Like clusters of Wisteria, they make sheets of color for sandy ground in Suffolk County, L. I. 3. Yucca. This century-plant-like flower is native to South Atlantic states with sandy soil. It has white flowers in early summer. The Bayonet and Adam's Needle. If you have a dry situation, try all three of these

\section{TAWINY DAY LILY, Hemerocallis fulva}

Large, double, orange-colored flowers with deeper shadings are borne on flower-stalks three feet high in June and July.

\section{ROSEMALLOW, Hibiscus}

Along the edges of the salt marshes, this is the largest wild flower of this region-great hollyhock-like blossoms, six inches across, of cerise-pink. It is one of the handsomest of all perennial plants if massive effects are desired. Although native of damp ground, it thrives in the garden or shrubbery and grows four feet high. Blooms in August. IRIS, Iris cristata

A very dainty Iris. Little blue flowers, like stars, that peep from the foliage in May. Grows three inches. Use freely in the rockery or at the edge of the border.

\section{GERMAN IRIS, Iris germanica}

Aurea. Rich chrome-yellow; large and fine.

Beauty. White, pale blue veins.

Beethoven. S. Lavender; F. purple.

Black Prince. S. deep velvety blue; F. purple.

DARIUS. S. yellow; F. lilac, white margin.

Dr. Bernice. S. bronze; F. crimson; large; beau tiful.

Florentina alba. Creamy white, faintly flushed lavender. Blooms early in the season. Fine for cutting.

Her Majesty. S. rosy pink; F. veined crimson. Exquisite.

Honorabilis. S. golden yellow; F. mahogany-brown.

Jacquesiana. S. bright coppery-crimson; F. maroon.

Mme. Chereau. White, frilled edges of clear blue.

Mrs. H. Darwin. S. white; F. violet at base. Freeflowering.

Pallida Dalmatica. S. lavender; F. deeper lavender. Superb. Three feet.

Purple Queen. Purple.

Queen of May. Lovely soft rose-lilac. Two and one-half feet.

ReBecca. S. buff; F. rich brown.

Rhein Nixe. S. pure white; F. deep blue, white edge.

SAPpho. S. white, frilled lilac; F. white, lilac at base. A fine variety.

JAPANESE IRIS, Iris kaempferi

Gold Bound. Double; white.

Mr. Hood. Light blue, shaded darker.

Pyramidalis. Double; light blue, veined blue.

Robert Craig. Grayish white with veins of violet.

Templeton. Double, lavender mottled red and pink.

Victor. Double; white, veins of purple in center of bloom.

\section{SIBERIAN IRIS, Iris sibirica}

Orientalis. Blue. I 5 cts. each; $\$ 1.00$ for IO, $\$ 8.00$ per 100 .

Snow Queen. White. I5 cts. each; \$I.00 for IO, $\$ 8.00$ for 100 .

\section{CATTAIL GAYFEATHER, Liatris pycnostachya}

The Gay Feather is native on the plains of Long Island and ranks next to the Viola pedata in the beauty of its purple flowers.

\section{SPIKE GAYFEATHER, Liatris spicata}

Tall spikes of purple flowers in July. This is a native of the southwestern prairies and is perhaps the showiest of the genus.

\section{LILIES}

\section{\$ I.00 each; \$7.50 for I0; \$60.00 per I00}

Lilies prefer shady situations where the ground may be kept cool and moist by a mulch of leaves and the protection of other plants. Plant the bulbs about six to eight inches deep, with a handful of sand under each bulb to provide drainage.

\section{ROYAL LILY, Lilium regale}

A new variety of which seems certain to attain great popularity because of its attractive coloring. The white flowers are shaded with pink and have canary-yellow centers. 


\section{PERENNIAL FLAX, Linum perenne}

Pale blue flowers from May to August on plants one and one-half feet high.

\section{PHLOX, paniculata}

Baron Vax Dedem. Very large flowers and trusses. Red. Bridesmaid. Tall, pure white with large crimson carmine eye.

Elizabeth Campbell. Pale pink.

Eugene Danzanvilliers. Lavender.

Europa. Large white flowers with crimson eye.

Ferdinand Cortez. Deep crimson, overlaid coppery bronze. A tall, strong grower.

Fred Passex.

Gen. VAn Heutz. Intensely brilliant salmon-red, with a white eye. Sure to please.

Henri Murger. White, pink eye.

INDEPENDENCE. Tall-growing white variety.

Jules Sandeau. Dwarf. Deep solid rose.

Le Mandr. Bluish violet blooms in fine, large panicles.

Limineaux. Extra-large, rose, carmine center.

Miss Lingard White, lilac eye. Five weeks earlier than others. Bloums till frost. Good foliage.

Mrs. Jenkins. Pure white. Very early.

Queen. White. Grows two to three feet high.

Rheinlander. Soft salmon-pink, deep red eye.

R. P. Struthers. Bright rosy red, crimson eye. One of the best.

Rynstrom. Deep pink, white center. Large trusses.

Sir Edwix Landseer. Bright crimson.

THor. Salmon-pink with a deep red eye. Individual flowers are as large as a half-dollar. A rare and handsome variety.

\section{MOSS PINK, Phlox subulata}

Here's an opportunity to make the showiest carpet on a sunny bank in May.

Alba. White. Lilacina. Lilac. Rosea. Rose

\section{PEONY, Paeonia}

Albert Crousse. Rose-white; fragrant. Late. \$I.50 each.

Armand Rousseat. Dark violet-rose. Midseason. 75 cts.

Duchesse de Nemolrs. Medium size; pure white crown, sulphur-white collar. Early. Fragrant. 75 cts. each.

Felix Crousse. A brilliant red, in fact, one of the best red varieties. Strong, vigorous grower. \$2.00 each.

Festiva Maxima. The most popular white variety. A tall, strong, vigorous grower with very large flowers. Early. \$i.00 each.

LA Tulipe. Flesh-pink, center and outer petals freely striped with carmine. \$1.50 each.

Lotis Van Houte. Brilliant rose. \$2.00 each.

Mine. Calot. Flesh, center darker. 75 cts. each.

Mme. Ducel. Silvery pink. 75 cts. each.
Mme. Forel. Violet-rose. Late. \$i.oo each.

Officinalis Rubro-plena. Brilliant crimson. This is the early-flowering variety so common in old gardens. Usually in bloom for Memorial Day. \$1.00 each.

Solfatare. Cream. Fragrant. Midseason. \$ 1.00 each.

Triomphe de l'Exposition de Lille. Very large, pale pink flowers; guard petals fade to nearly white. Fragrant. \$ $\$$.०0 each.

\section{COWSLIP PRIMROSE, Primula veris}

In shades of yellow and red. Come in May and take them in bloom in pots. Make a children's garden with them.

\section{OXLIP PRIMROSE, Primula elatior}

Pale yellow. Grows four to eight inches high.

\section{PEARLWORT, Sagina subulata}

A close, green moss one inch high. Very attractive and happy in the rock-garden.

\section{AZUREA SAGE, Salvia azurea}

One of the rare blues that are always welcome. In early autumn it waves its slender wands of sky-blue flowers four feet high.

\section{STONECROP, Sedum}

In variety. A creeping, moss-like plant, with bright yellow star-like flowers in June. Delightful among rocks and on sand banks like Moss Pink.

\section{THRIFT, Limonium latifolium, Statice latifolia}

A valuable rock-plant with immense heads of very showy and lasting small blue flowers in August. Grows two feet high.

\section{STOKESIA LAEVIS, blue and white}

One of the most desirable of perennials. Clusters of blue aster-like blossoms in August and September. The bluest flower in the garden in its season.

\section{SPIDERWORT, Tradescantia}

An old-fashioned plant two feet high, with bright blue flowers from May to August. Closes at noon.

\section{COMMON YUCCA, Yucca filamentosa}

This is one thing that will grow in poor soil. The swordlike leaves remain green all winter and in July there is a stately spike five to six feet high loaded with beautiful cream-colored bells. Excellent at the seaside. 

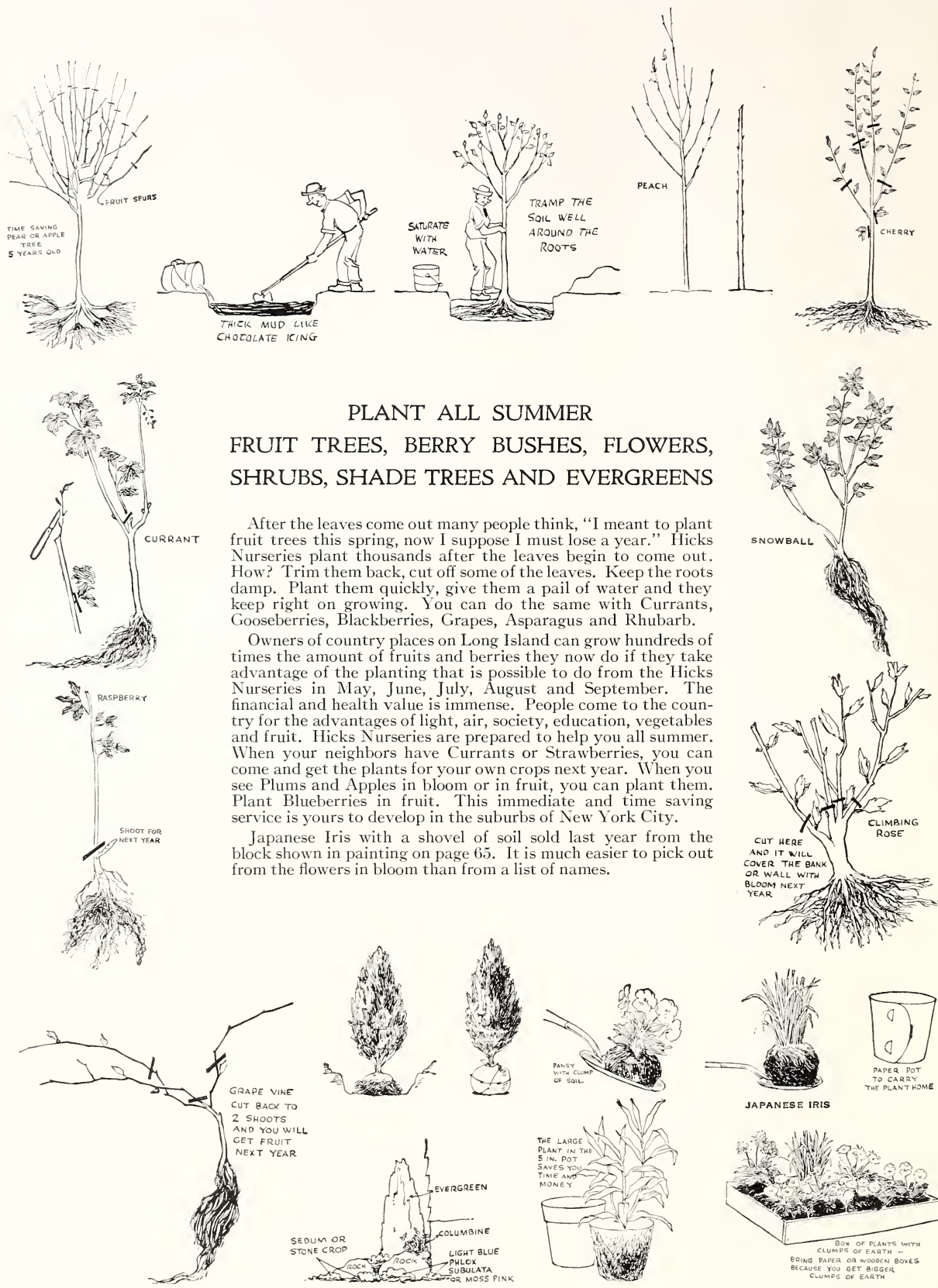

\section{PLANT ALL SUMMER}

FRUIT TREES, BERRY BUSHES, FLOWERS, SHRUBS, SHADE TREES AND EVERGREENS

After the leaves come out many people think, "I meant to plant fruit trees this spring, now I suppose I must lose a year." Hicks Nurseries plant thousands after the leaves begin to come out. How? Trim them back, cut off some of the leaves. Keep the roots damp. Plant them quickly, give them a pail of water and they keep right on growing. You can do the same with Currants, Gooseberries, Blackberries, Grapes, Asparagus and Rhubarb.

Owners of country places on Long Island can grow hundreds of times the amount of fruits and berries they now do if they take advantage of the planting that is possible to do from the Hicks Nurseries in May, June, July, August and September. The financial and health value is immense. People come to the country for the advantages of light, air, society, education, vegetables and fruit. Hicks Nurseries are prepared to help you all summer. When your neighbors have Currants or Strawberries, you can come and get the plants for your own crops next year. When you see Plums and Apples in bloom or in fruit, you can plant them. Plant Blueberries in fruit. This immediate and time saving service is yours to develop in the suburbs of New York City.

Japanese Iris with a shovel of soil sold last year from the block shown in painting on page 65 . It is much easier to pick out from the flowers in bloom than from a list of names.
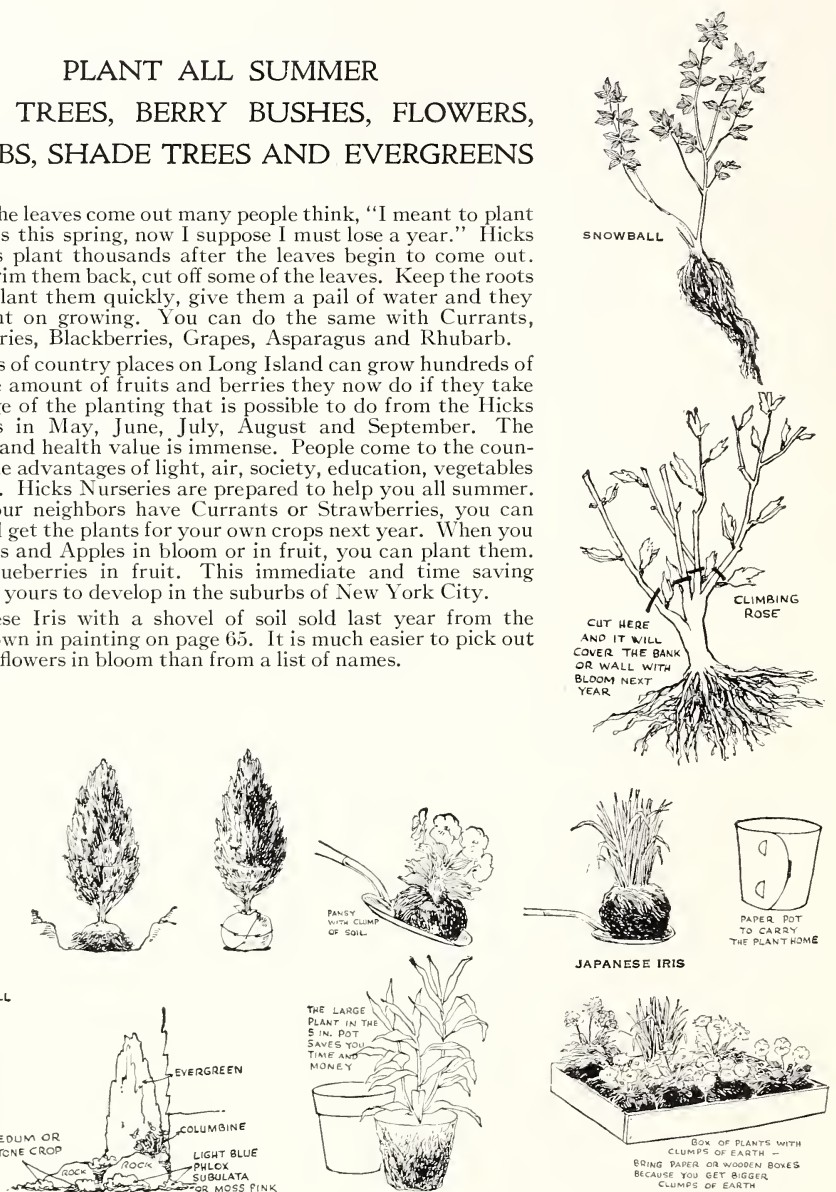

JAPANESE IRIS

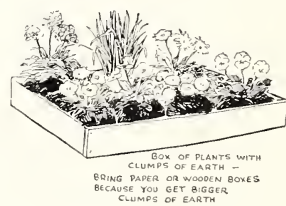




\section{PLANTATERIA (Help Yourself)}

$\mathrm{B}$ UDGET your country place for $\$ 10.00$ per month all summer. We will be glad if you can make it $\$ 50.00, \$ 100.00$ or $\$ 500.00$. We will promise you satisfaction and a good investment whatever the amount. This enthusiasm of ours for summer planting is based not only on desire of income to meet payroll, but on the fact that you can be added to the thousands who are already planting from Hicks Nurseries all summer.

The idea of spring and fall planting only has grown up from the fact that in spring and fall plants can be shipped without earth on the roots and in some varieties like Apples and Poplars can be stored in cellars like sheaves of wheat. Leonard Barron, editor of Garden Magazine, in an editorial on summer planting recommending the system of Hicks Nurseries says that spring and fall is the time when planting can be done most carelessly. The best way for moving a large variety of plants, especially those suitable for sandy soil like Long Island is with ball of earth. If that method is used in the summer it is equally successful as if used in spring and fall. If you do your transplanting in the best way not in the most careless way, the season of the year is of very little or no importance.

The old idea of planting in spring and fall they make roots in late summer and autumn. only, is abandoned at the Hicks Nurseries. Next year they make a normal or nearly normal Eighty per cent or more of the different classes of plants can be transplanted safely all summer. Many of them do better with summer planting. They have the growth of the present season and are not cut back,

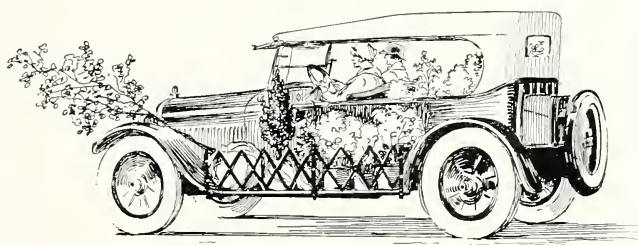

Come to the nursery, select what you want. In many cases it can be dug immediately, packed and put in your car growth, instead of short growth as when moved in the old way with bare roots in spring or autumn. Twenty - five years ago Hicks Nurseries demonstrated this with evergreens, ten years ago with shade trees and shrubs.

\section{POTTED PLANTS \\ Each, $\$ .60$ \\ Ten, $\$ 5.00$}

YARROW, Achillea, the Pearl

GOLDENTUFT, Alyssum saxatile

DROPMORE BUGLOSS, Anchusa dropmore opaI

YELLOW CAMOMILE, Anthemis tinctoria

AMERICAN COLUMBINE, Aquilegia canadensis

MUNSTEAD WHITE COLUMBINE, Aquilegia nivea

SEA PINK, Armeria plantaginea

WHITE MUGWORT, Artemisia lactiflora

ENGLISH DAISY, Bellis perennis, white and pink

CANTERBURY BELLS, Campanula medium, pink, white and blue

PEACHLEAF BELLFLOWER, Campanula persicifolia, white and blue

CHIMNEY BELLFLOWER, Campanula pyramidalis, blue

MOUNTAIN-BLUET, Centaurea montana

SNOW-IN-SUMMER, Cerastium tomentosum

PINK TURTLEHEAD, Chelone lyoni

LANCE COREOPSIS, Coreopsis lanceolata

LARKSPUR, Delphinium belladonna

LARKSPUR, Delphinium hybridum

MAIDEN PINK, Dianthus

PINKS, mixed; Dianthus mixed

FOXGLOVE, digitalis, white, pink and purple

LOW GLOBETHISTLE, Echinops humilis

PURPLE OREGON FLEABANE, Erigeron grandiflorus

MISTFLOWER, Eupatorium coelestinum

COMMON PERENNIAL GAILLARDIA, Gaillardia aristata (grandiflora

BABYSBREATH, Gypsephila paniculata

HIBISCUS, white, red and pink
CATTAIL GAYFEATHER, Liatris pysnostachya

GAYFEATHER, Liastris scariosa

LILY, Lilum album

GREAT SPECIOSUM LILY, Lillium speciosum magnificum

PERENNIAL FLAX, Linum perenne

WHITE LUPINE, Lupine albus

SUN-DIAL LUPINES, Lupinus perennis

LUPINUS ROSEUS

FORGET-ME-NOT, Myosotis scorpioides

PHLOX, Bridesmaid

PHLOX, Independence

PHLOX, Mrs. Jenkins

PHLOX, Jules Sandeaux

PHLOX, Miss Lingard

PHLOX, R. P. Struthers

BLUE PHLOX, Phlox divaricata

BALLOON FLOWERS, Platycoden grandiflorum white and blue

LARPENTEA PLUMBAGO

PYRETHRUM, double French

CONEFLOWER, Rudbeckia purpurea

AZUREA SAGE, Salvia azurea

SHOWY STONECROP, Sedum spectabile

SPIREA ASTILBE, Astilbe astilboides

JAPANESE SPIREA, Astilbe japonica

STOKESIA LAEVIS, blue and white

BASTARD SPEEDWELL, Veronica spuria; amethystina

CUMP SPEEDWELL, Veronica longifolia subsessilia 


\section{FRUITS AND BERRIES}

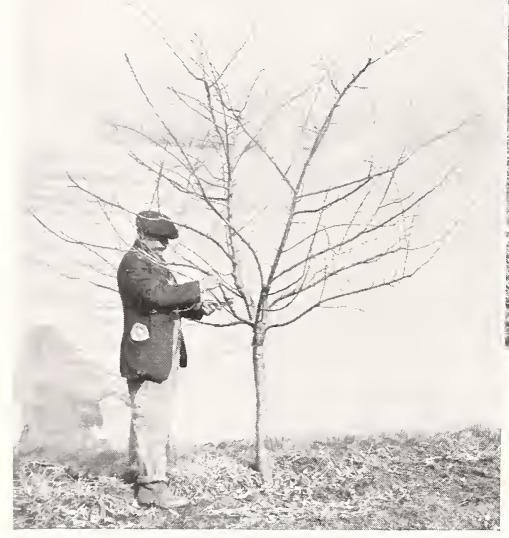

Time-saving Apple photographed last winter. These trees are almost big enough for a child to climb. They are well set with fruit blossoms, and many of them should bear the first or second year after you plant them. The time-saving service of Hicks Nurseries extends to other departments-Shade Trees, Evergreens, Shrubs and Flowers

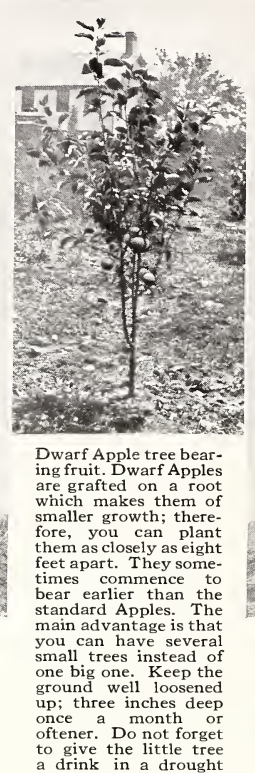

\section{FRUITS}

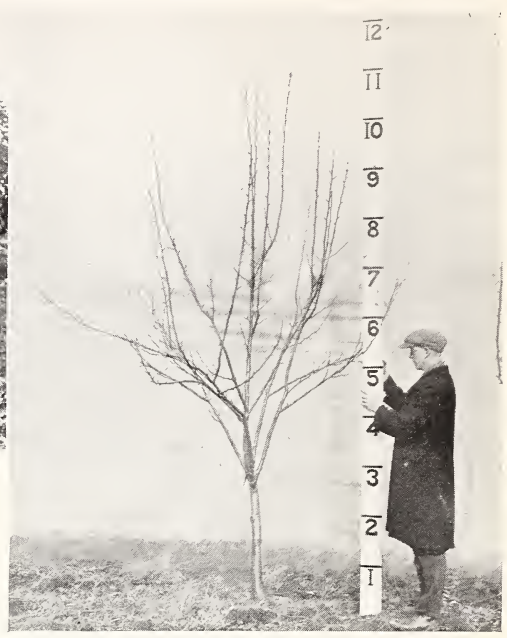

Time-saving Pear. These we have grown for several years. They have been planted six feet apart and cultivated in both directions, are well set with blossom buds and may save you several years waiting for fruit. As these two pictures show, the Pears are more upright and occupy less room than the Apples, therefore you can space them twenty feet apart or even closer

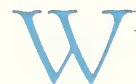

HAT is the poor commuter to do for fruits? His wife goes to the chain stores and buys the essentials, cereals and meats, and has not money for sufficient Apples, Pears, Raspberries, Celery, Lettuce, and Spinach. Everyone knows the importance of bulky foods. Everyone is hungry for the sweet, sour, and bitter of fruits and is anxious to have plenty of vegetables and salads. Perhaps you think you can buy cheaper than you can raise, but that is lazy thinking and lazy work, and you do not buy plenty. If fruit is raised at home there may be plenty in years of a good crop and a balanced ration is possible. Hicks Nurseries has not an answer to all these problems for every month in the year, but it is willing to help and anxious to learn from you what to pass on to the next.

For new food plants, see Beach Plum, page 56; Blueberry, page 58; Shad-bush or Juneberry, page 54 ; Hazelnut, page 5 I.

\section{APPLES}

Standard Apples are placed thirty feet or more apart. You can put them closely on a limited area and keep them cut back.

Dwarf Apples can be placed as close as eight feet.

$$
\begin{aligned}
& \text { Height Age Each Ten } \\
& 5-6 \mathrm{ft} .2 \text { years } \$ .75 \quad \$ 6.50 \\
& \text { DWARF }
\end{aligned}
$$

Age, 2 years; Each, $\$ 1.00$; Ten, $\$ 9.00$

\begin{tabular}{rrrrr} 
& \multicolumn{4}{c}{ True-SAving } \\
Height & Age & Spread & Each & Ten \\
$7-10 \mathrm{ft}$. & 6 years & $4-6 \mathrm{ft}$. & $\$ 8.00$ & $\$ 70.00$ \\
$7-10 \mathrm{ft}$. & 6 years & $6-9 \mathrm{ft}$. & 12.00 & 100.00 \\
$12-16 \mathrm{ft}$. & 16 years & $14 \mathrm{ft}$. & 50.00 &
\end{tabular}

\section{SUMMER VARIETIES}

EArly Harvest. Similar to Yellow Transparent. Pleasantly acid. Late July and early August.

Oldenberg (Duchess). Yellow with streaks of crimson; juicy, acid. Middle of August. Bears early.

Red Astrachan. Red; acid. First half of August.

Sweet Bough. Large; yellow; good for baking.

Yellow Transparent. The earliest variety-ripens July 20. Usually bears the first or second year after planting. 


\section{FRUITS}

\section{APPLES}

\section{FALL VARIETIES}

Fall Pippin. Large; clear yellow; acid. October.

Gravexsters. If you can have but one Apple and are not anxious for a very early variety, this will cover the entire season for dessert and cooking from the middle of August to the last of September.

IcIstosh. The most showy Apple in September and October.

TraNsceNDENT CRAB. Yellow with red cheek. September.

Wealthx. Red; fine quality. September to December.

\section{WINTER VARIETIES}

BALDWIN. Red; crisp, juicy and rich. November to April.

Delicious. Large; red.

HubBardstox (HubBardston's NonSUCH). Red; bears young. October to January.

King. Large; red. October to January. Northers Spy. Red; juicy. November to March.

Opalescent. Very attractive; brilliant red; yellow flesh, tender, juicy. November to January.

Rhode Island Greening. Large; greenish yellow; fine grained, tender, and rich. November to February.

Rome BeAutr. Large; red.

RONBLRY (RLSSET). A standard winter Apple; flesh greenish white, crisp. Keeps late.

SPITZENBURG. Subacid; aromatic; red.

STARk. Large; red and yellow. Keeps until spring.

Stamanan Winesap. High quality; red; juicy.

Twentr-Ouxce. Fruit large; yellow and red; subacid. September to early winter.
Home-canned fruits and vegetables are a source of pride and tables are a source of pride and
economy. Besides the things we grow, Hicks Nurseries will be glad to direct you to a source of supply of Blueberries, Junerries, Beach Plums and other wild fruit. berries and nuts.

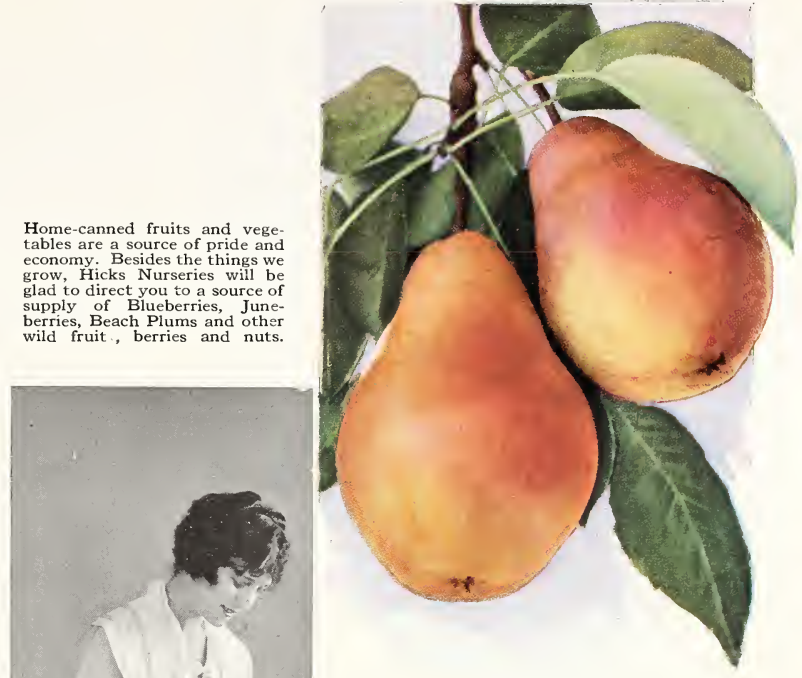

Bartlett Pears are favorites with everybody. They ripen in September. An early fruit of smaller size is Clapp Favorite. Many Pears are so soft they do not readily reach us from distant orchards and to have the best you to have the best you must enough to have plenty ant some to give away

\section{DWARF APPLES}

Can usually be supplied in the following varieties:

BALDWIN

Delicious

FAUETSE

Gravenstein

ICINTOSH

NortherN Spy

OLDENBLRG

Rhode IsLAND Greenivg

STAYMAN WINESAP

Yellow TraNSPARENT

\section{WEALTHY}

\section{TIME-SAVING APPLE TREES}

Four or five years ago we started plantations of Apple trees to save you time. These trees will save you some time and money. Extra-sized trees are as follows:

\section{BALDIIIN}

EARLY HARVEST

Fall Pippin

GRAVENSTEIN

KING

MCINTOSH RED

NoRTHERN SPY

\section{OldENBURG}

RED ASTRACHAY

RHode IslaNd GREening

ROXBURY RLSSET

STARK

Twenty-OCXce

\section{PEARS}

Standard Pears make narrow trees perhaps fifteen feet wide until they get thirty rears old.

Dwarf Pears can be placed eight feet apart.

İeight, 5-6 ft.; Age, 2 years; Each, \$1.2.5; Ten, $\$ 11.00$

DWARF

Height, 2 ft.; Age, 2 years; Each, \$.75; Ten, 96.50

Time-SAVING

$$
\begin{array}{ccccc}
\text { Height } & \text { Age } & \text { Spread } & \text { Each } & \text { Ten } \\
7 \mathrm{ft} & 6 \text { years } & 2-3 \mathrm{ft} . & \$ 8.00 & \$ 70.00 \\
& & 3-6 \mathrm{ft} . & 12.00 & 100.00
\end{array}
$$

Anjou. Large; russet; rich flavor. October and November. Bartlett. Yellow. August and September.

Buerre Bosc. Russet; juicy and delicious; Oct. to Nov. Buerre Clairgeau. Rich yellow. Late October.

Buffum. Medium; russet; juicy and sweet. Sept. and Oct. 


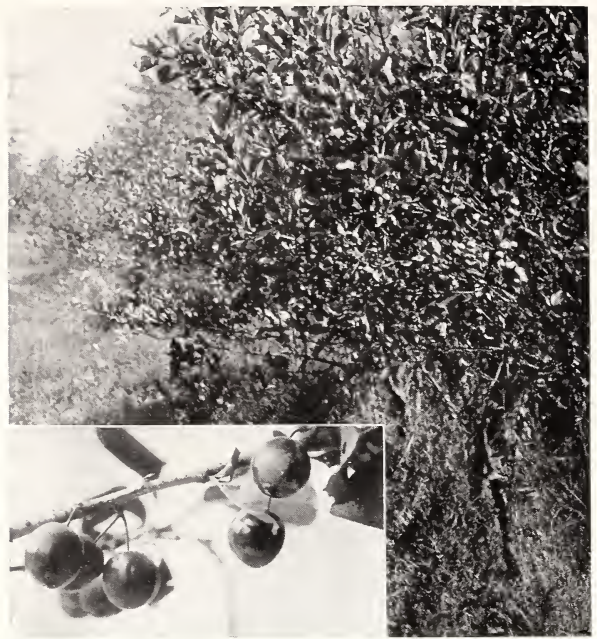
A planting of Beach Plums. Edwin Foster, Central Park, L. I. finds $\mathrm{He}$ is looking for larger and better varieties

Clapp Favorite. Like the Bartlett but two weeks earlier. August.

Duchesse D'Axgouleme. Very large. Yellow; flesh melting and sweet. October and November.

Elizabeth. Among the best summer Pears of good flavor, late autumn.

Howell. A profuse bearer. Very delicious. Sept. and Oct.

Josephine de Molines. Buttery, juicy and perfumed. Ripens from December to March.

KIEFFER. Coarse, yellow fruit, good for cooking and canning. November and December.

LaWrence. Medium size; yellow. Keeps well in winter.

Louise Boxne de Jersey. Fruit from medium to large; excellent in quality; ripening in October.

Osbaxd Summer. Medium size; yellow; flesh white, sweet. Ripens in August.

Pres. Drouard, Resembles the Anjou. Ripens in October.

Rossney. Fruit of large size, excellent flesh and flavor. September.

Seckel. Fruit small, brown. The richest and highest flavored Pear known. September.

Sheldon. Russet fruit; juicy and luscious. October.

Tyson. Excellent quality. Ripens in late August.

Wilder Early. Bright yellow; sweet. Late August.

Winter Nelis. Russet; juicy and sweet.

\section{DWARF PEARS}

Dwarf Pears can usually be supplied in the foilowing:

\section{BARTLETT}

BUERRE BOSC

Clapp Favorite

Duchesse D'ANGOULEME

\section{PLUMS}

Plant 10 to $18 \mathrm{ft}$. apart.

Height, 5-7 ft.; Age, 2 years; Each, $\$ 1.50 ;$ Ten, $\$ 12.50$

Abundance, A Japanese Plum bearing very heavy crops every year. Needs severe thinning. Ripens early in August. It is red, juicy, and sweet.

Apple. A Burbank hybrid with Japanese ancestry, and therefore very vigorous and productive. Fruit large and attractive; deep reddish purple in color; flesh red and firm. August.

Bradshaw. European. Juicy and sweet. August.

Green Gage, European. Small. August.

Lombard. European. Good for preserving. August.

October Purple. Very juicy; sweet. October.

RED June. Japanese. Red and yellow; very early.

Wickson. Japanese from Burbank. Yellow, sweet. September.

\section{BEACH PLUMS}

Wild on the beaches and sandy portions of Long Island. They make bushes eight feet high. Use them for hedges, holding sand dunes, shrubbery planting, with oaks and pines and in the garden. (See page 56.)

$\begin{array}{cccc}\text { Height, } 1 \frac{1}{2}-2 \mathrm{ft} . ; \\ 3 \mathrm{ft} . ; & .75 ; & 6.50 ; & 60.00\end{array}$

\section{CHERRIES}

Mr. Hodenpyle, of Locust Valley, trains them like grapes, covers with mosquito netting.

Don't let the birds scare you from planting Cherries.

Height, 4-6 ft.; Age, 2 years; Each, \$1.50; Ten, \$12.50

Black Tartarian. Purplish red; sweet, juicy.

EARly Richmond. Acid; excellent for pies and canning.

English Morello. Acid; late.

Montmorency. Acid; midseason.

NAPOLEon. Large; rich, sweet flavor; juicy. Commonly called "Ox-heart,"

SchмidT's. Black; meaty; crisp; sweet.

Yellow Spanish. Very large; yellow; sweet.

WINDSOR. Dark red; sweet.

\section{PEACHES}

Peaches bear early, sometimes the second year after planting. Cut them back to keep them low and round. Scrape away the earth, cut out the borers under the jelly. A good rule is to plant a dozen trees once in three years.

Height, 4-6 ft.; Age, 1 year; Each, \$ .60; Ten, \$5.50

Belle of Georgia. Large; white; good quality. August. CARMan. Brilliant red skin; good quality. July.

Champion. White; tender; juicy. August.

Crawford Early. Yellow; juicy. Early September.

Crawford Late. Yellow; very large. September.

Elberta. Yellow; large; excellent for shipping. August.

GLoBE. Yellow-colored fruit; good. September.

J. H. Hale. Yellow; larger than the Elberta. August.

Mountain Rose. White; sweet. August.

OLdmixon. White; flavor excellent; fine for canning. Sept. Stevens' Rareripe. White; September. 


\section{QUINCE}

Two trees may be enough to supply you with quince jelly through the winter.

Height, 3-4 ft.; Age, 2 years; Each, \$1.25; Ten, \$11.00

Champion. Fruit long; very large and handsome

OrANGE. Fruit round. Ripens in midseason.

\section{GRAPES}

Grapes grow almost anywhere, house, garage, trellis or pole. Prune them back severely so but few branches grow. On trellis plant six feet apart.

Age, 1 year; Each, \$ .30; Ten, \$2.50; Hundred, $\$ 20.00$

CONCORD. Black; very popular; early.

DelawARE. A sweet, little red Grape.

Moore's Early. Similar to the Concord.

Niagara. The handsomest white Grape.

Pocklington. White; sweet; rich.

SALEM. Dark red; juicy; good flavor.

WORDEx. Large, earlier and better than Concord.

\section{CURRANTS}

Twelve will supply a family; two dozen a surplus for jelly and canned currant juice. For the currant worm use Hellebore Powder.

$$
\begin{array}{ccccc}
\text { Height } & \text { Age } & \text { Each } & \text { Ten } & \text { Hundred } \\
1 \mathrm{ft} . & 1 \text { year } & \$ .25 & \$ 2.00 & \$ 18.00
\end{array}
$$

Cherry. Large; red; acid.

FaY's Prolific. Red; large; long bunch.

White Grape. Excellent. Sweeter than the red Currant.

\section{GOOSEBERRIES}

Gooseberries are close relatives of Currants. They each require about five foot space.

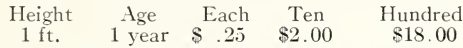

Downivg. Sweet; large; quality very good; red.

RED JACKet. Fruit of especially high quality, juicy; red.

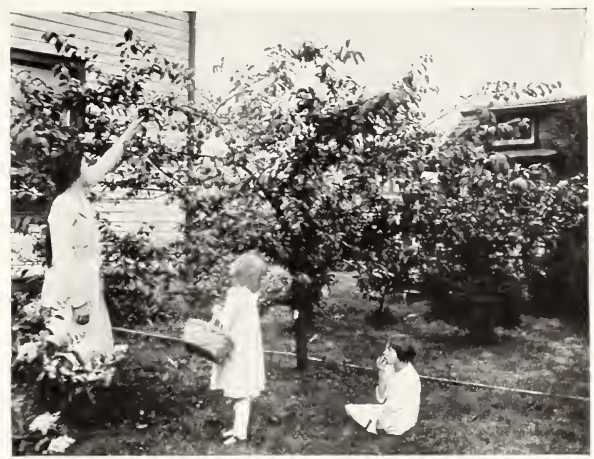

Japanese Plums are perfectly at home. They bear so heavily that it is frequently necessary to thin out the fruit and prop up the branches. When ripe the flavor is a pleasant mingling of sweet and acid

\section{RASPBERRIES}

Many Long Island gardeners boast of a good patch of Raspberries. They keep them pruned, cultivated and fertilized. Plant $3 \times 6 \mathrm{ft}$.

Age, 1 year; Each, \$ .15; Ten, \$1.20; Hundred, $\$ 10.00$

Cumberland. Black. Large; juicy; sweet.

Cuthbert. Red. Midseason; spicy flavor.

Golden Queen. A yellow Cuthbert.

GREGG. Black. Sweet; rich.

MARLboro. Red. Large; juicy.

Miller's Red. Red. Large.

Plum Farmer. Black. Large; early and high quality.

St. Regis. Everbearing Red. July and September.

\section{BLACKBERRIES}

The more rampant spreading of the blackberries should not keep you from growing them. Some tie them up like grapes.

Age, 1 year; Each, \$ .15; Ten, \$1.20; Hundred, $\$ 10.00$ EARLY HARVEST. Sweet; early; ripens over a long season. ERIE. Berries very large; quality good. Midseason.

Lucretia Dewberry. Ripens earlier than the high Blackberries and sure to have a crop when the others winter-kill. SNyder. Medium size; good flavor; sweet. Midseason.

\section{IMPROVED EUROPEAN FILBERTS}

The four named varieties of Filberts described here have been selected from a list of a dozen of the best brought from northern Germany some years ago by a nut specialist in Rochester, New York. They are perfectly hardy, thrifty growers and bear and mature their nuts perfectly. They will thrive in any ordinary garden soil and practically will thrive in most parts of the Lnited States. They are hardy in the North.
The Italian Red and Red Lambert are large pointed nuts and the other two do not have quite such large nuts, but should be selected with the others for pollination. At least two plants and different varieties are necessary for pollination of course, in order to get a quantity of fruit.

Height, 2-3 ft.; Age, 2-3 years; Each, \$2.00; Ten, \$17.50

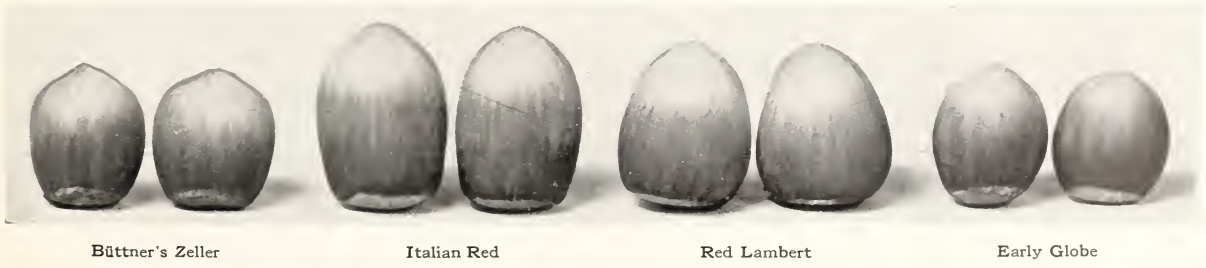




\section{WHITESBOG BLUEBERRIES}

To cultivate Blueberries is new. Bigger, better Blueberries are new. Where, how, what crop and profit to expect is not generally known. The U. S. Dept. of Agriculture, J. J. White Inc., New Lisbon, N. J. and Hicks Nurseries are ready to supply you facts and plants.

The plants from Hicks Nurseries are guaranteed to grow satisfactorily or replaced free. This guarantee is of value in selecting soil and methods of culture. This is the place and time to buy. Blueberries are transplanted like their relatives, Rhododendrons and Azalea with ball of earth and time of year is of little or no importance. The stock offered is the first opportunity to get plants in quantity. Heretofore small quantities have been offered for experiment.

Where to plant them? Are there Blueberries in the woods in your vicinity? Do you grow Rhododendrons, Azaleas and Laurel? There is no mystery about Blueberry culture. They like a layer of decaying leaves, the same as other plants in the woods.

Limestone soil and clay is not favorable to plants of this family. In such situations the soil can be prepared with decaying leaves, peat, sawdust, sand and aluminumsulphate. For details write U.S. Dept. of Agriculture.

Commercial culture of Whitesbog Blueberries should be started on Long Island at once. There are thousands of acres of such land on Long Island from six inches to two feet above the water table. They will grow on higher land also.

How prepare? Plow, harrow, plant $8 \mathrm{x}_{4} \mathrm{ft}, \mathrm{r}, 36 \mathrm{I}$ plants per acre.

The gross returns are over $\$ 1,000$ per acre.

Prices, Nursery-Grown Plants 10-12 in. High

Varieties: Rubel, Sam, Harding, Grover, 1 plant, \$1.60; 10 plants, \$15.00; 100 plants, \$110.00. Varieties Pioneer, Cabot, Adams, 1 plant, $\$ 2.00 ; 10$ plants, \$1\$.00; 100 plants, $\$ 135.00$. Extra size field-grown Blueberry plants $1 \frac{1}{2}$ to 3 ft., $\$ 3.50$ to $\$ 5.00$.

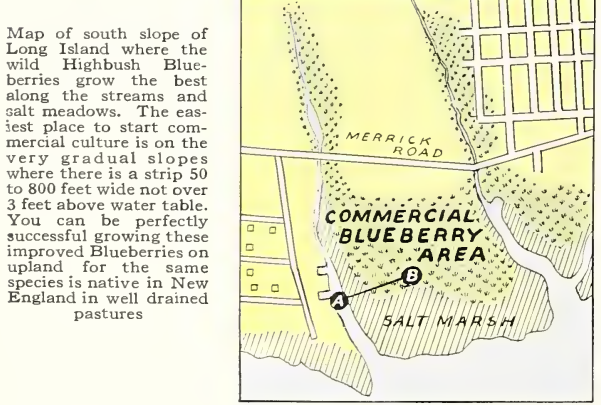

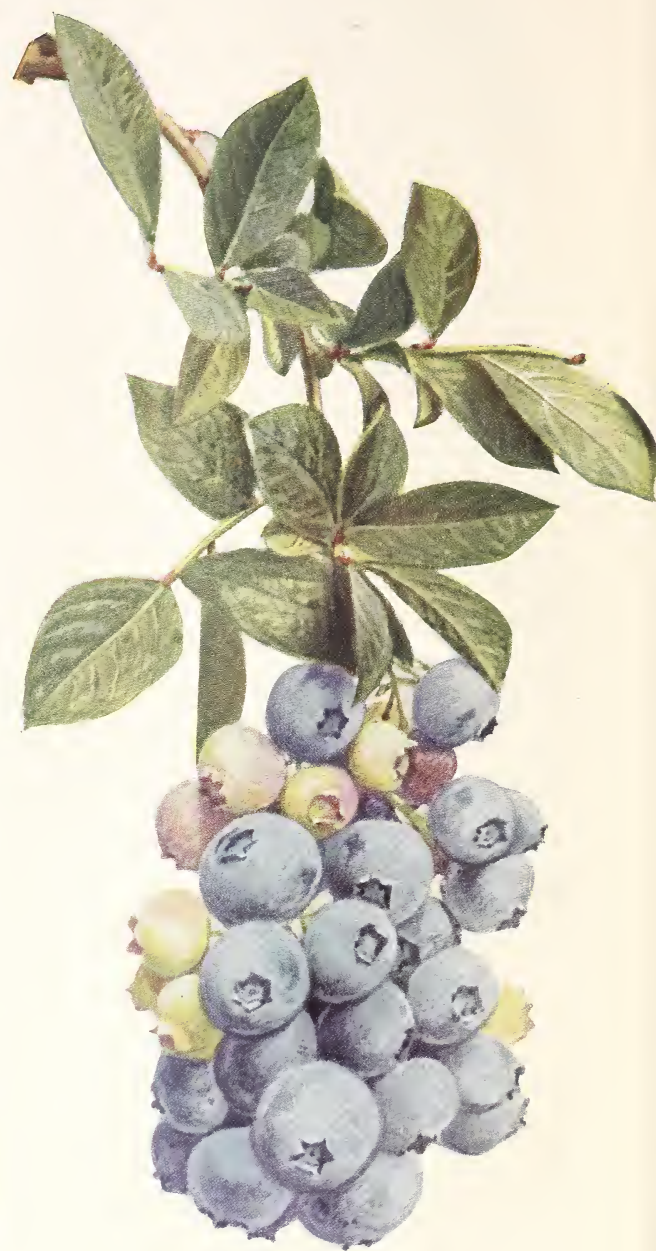

« FROM 100 TO 800 FEET —

B

(A)

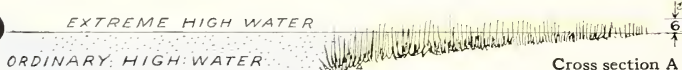

Cross section A B on Map. In the wettest places the wild bushes are on mounds. The Highbush Blueberry is native also to dry upland 


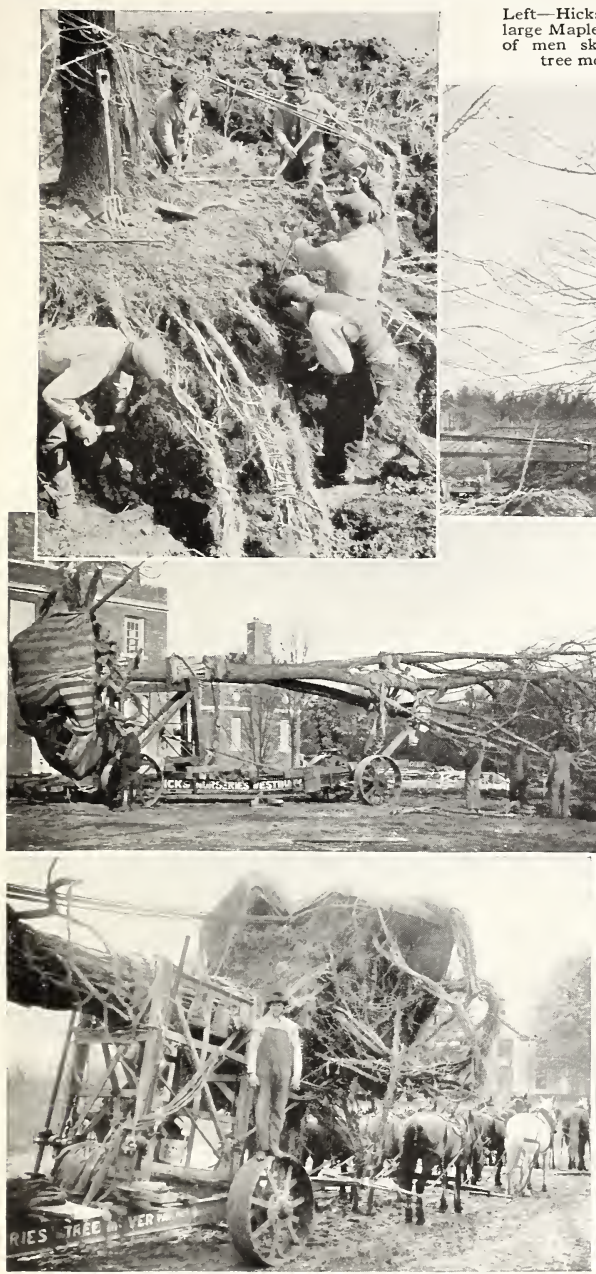

These highly developed appliances and skilled operators under Oscar Wicky, Harry Carr and other tree moving experts are like skilled surgeons and right equipment
Left-Hicks system of dissecting out and bundling the feeding roots of large Maple. These roots are not cut off with a mattock, but a large crew
of men skillfully dissects out and preserves them. For other details of tree moving process developed by Hicks Nurseries, see pages $16-28$

\section{LARGE TREE MOVING}

- HE Hicks inventions for moving large trees are only a part of the service. The best part for you is the knowledge of the Hicks staff of what is worth moving; what is not worth moving; the skill to move trees rightly and the aid in caring for the trees during convalescence. The sympathetic care of you and your gardener is essential to the best results.

The best way to develop your place is to come to the Hicks Nurseries, see the machines and methods, see what has been done in large tree moving in the vicinity, have a representative look over your needs and your region, prepare an estimate and order such part of the work as you think best. Many types of large tree moving can be done with equal success at any time of the year. 


\section{Standardized Plant Names. Compiled by American Joint Committee on Horticultural Nomenclature, Salem, Mass. $\$ 5.00$. The names in this catalogue have been arranged in accordance with above book. We strongly advise you to buy this book for it will help you in developing your place.}

\section{COMMON NAME INDEX}

\begin{tabular}{|c|c|c|c|c|}
\hline PAGE & PAGE & PAGE & PAGE & PAGE \\
\hline Abelia ..............46 & Cherry, Nanking........56 & Gooseberries..........77 & Mulberry, Acid .........62 & Spindle Tree.... \\
\hline Almond, Double Flowering. 51 & Cherry, Flowering.........2s & Grapes...... & & Sneezeweed, Common.... \\
\hline Althea, Bush..........54 & hokeberry,....... & Gum, Sweet..........26 & Nanking Cherry . . . . . . .556 & Snowball, Common.......58 \\
\hline Amethyst Erygo. ..........69 & Chrysanthemum ....... & & New and Rare Plants. .60-62 & Snowberry ........... \\
\hline Ampelopsis, Porcelain . . . 60 & Clematis, Sweet Autumn..59 & Hazel, Tree. . . . . . . . . & & Snow in Summer. \\
\hline Andromeda, Mountain, ....4s & Columbine ..........66 & Hazelnut, American . . . . . . 53 & $.21-24$ & Spiderwort.... \\
\hline Apples..........74-75 & oralberry $\ldots \ldots \ldots \ldots \ldots 57$ & Heathermint. . . . . . . 61 & & Spirea....... \\
\hline Saving. .75 & Cornelian Cherry .......53 & Heather. & Pachysandra, Japanese.. ..48 & Spruce. \\
\hline g Crab. 28-62 & otoneaster. . . . . . . 47-61 & Heliopsis, Pitcher. . . . . 69 & erry........48 & eaf .....57 \\
\hline$\ldots \ldots .41$ & lip Primrose.......71 & Hemlock. . . . . . . .42-44 & .76 & nswort. . . . . . . .54 \\
\hline$\ldots \ldots \ldots 58$ & perry Bush .........5s & $\ldots \ldots 47-48$ & & op $\ldots \ldots \ldots \ldots \ldots 71$ \\
\hline$\ldots \ldots 67$ & Crab Apple, Arnold . . . . . .62 & Hollyhock........ & $.75-76$ & nese.... \\
\hline ...46-51-52 & Currants........... & Honeysuckle . . . 55-59-60-62 & & $t \ldots \ldots \ldots \ldots 53$ \\
\hline$\ldots \ldots \ldots 71$ & Cypress...........40-41 & Hornbeam............28 & & \\
\hline & & Hydrangea ...........54 & mon......48 & Sweetleaf, Asiatic . . . . . . . 57 \\
\hline $\begin{array}{l}\ldots \ldots \ldots \ldots 69 \\
\ldots \ldots \ldots 46\end{array}$ & & Iris & $\begin{array}{l}\text { Perennial Flax......... } \\
\text { Phlox. . . . . . . . }\end{array}$ & Sweet William...........69 \\
\hline Japanese.......52 & 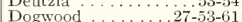 & Ivy, English . . . . . . . & $\ldots \ldots \ldots 32-34$ & \\
\hline & Day Lily, Tawny........70 & & arf........67 & Maple \\
\hline$\cdots 55$ & & & $7-69$ & \\
\hline $.56-77$ & nkianthus, Redvein .....61 & & & Tre \\
\hline$\ldots \ldots \ldots 24-25$ & $\operatorname{in} \ldots .61$ & $.38-39$ & & Tre \\
\hline$\ldots \ldots 67$ & reens. . . . . . . . . 29-44 & & Beach........ & Tre \\
\hline $\begin{array}{r}\ldots 60 \\
\text { an } \quad .59\end{array}$ & Evergreens Broad-Leaved & 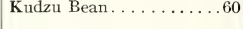 & .76 & Creeper... \\
\hline rican....59 & $\ldots \ldots \ldots \ldots \ldots \ldots 45-48$ & Lab & & .28 \\
\hline Spirea) ...52 & & .68 & $\ldots \ldots \ldots \ldots$ & Turtlehead, Pink... \\
\hline sh....58 & .77 & La & Pussywillow, Japanese. & \\
\hline $\log \ldots 78$ & $\ldots 35-36$ & & & Viburnum, Wright \\
\hline & vine, China.....6 60 & oping .....48 & Oui & Vines ............59-60 \\
\hline$\ldots \ldots+67$ & hia $\ldots \ldots \ldots \ldots$ 54-61 & $\ldots \ldots 57-62$ & & \\
\hline $\begin{array}{l}\ldots \ldots \ldots 59 \\
\ldots \ldots \ldots 46\end{array}$ & $\begin{array}{l}\text { Foxglove } \ldots \ldots \ldots \ldots \ldots \\
\text { Fruits . . . } \ldots \ldots \ldots \ldots \\
\end{array}$ & -of-the-Valley . . . . . 68 & $\begin{array}{l}\ldots \ldots \cdots \\
\ldots \ldots \ldots+56\end{array}$ & \\
\hline .66 & & Linden............... & & \\
\hline .66 & & & & \\
\hline & $65-71$ & 28 & & \\
\hline Butterny Busn...... & & & Rosemallow......... & Witch-Hazel \\
\hline & $\ldots 28$ & .69 & & \\
\hline .48 & Lov & & $.13-28$ & Ya \\
\hline & & $\ldots 48$ & $.49-58$ & \\
\hline .39 & $\ldots \ldots 28$ & 48 & s & ading... . \\
\hline & $\ldots \ldots 66$ & Mountain Silverbell . . . . .662 & Silverbell, Mountain......62 & Yucca, Common .........71 \\
\hline
\end{tabular}

LATIN NAME INDEX

\begin{tabular}{|c|c|c|c|c|}
\hline $\mathrm{P}$ & PAGE & PAGE & PAGE & PAGE \\
\hline Abies............35-36 & Chamaecyparis ......40-41 & Hamamelsis . . . . . . . 54-62 & Malus arnoldiana .......62 & Salix multinervis. . . . . . 57 \\
\hline cer ..........17-18-50 & Chelone lyoni...........67 & Hedera helix...........59 & Mitchella repens........48 & Salvia azurea.......... \\
\hline$\ldots \ldots 66$ & Chrysanthemum pompon .68 & Helenium aut umnale. . & Morus acidosa...........62 & Sedum.... \\
\hline hidia arguta . . . . . . 59 & Clematis paniculata.....59 & Helesia monticola.... & Myrica............... & Spirea... \\
\hline ea.............66 & Clethra alnifolia........53 & thoides & & olia . \\
\hline$\ldots \ldots \ldots 66$ & Convalleria majalis......68 & pitcheriana... & Nyssa sylvatica..... & .57 \\
\hline$\ldots \ldots 66$ & lata. . .68 & is fulva. . & & \\
\hline$\ldots \ldots 50$ & $\ldots 27-53-61$ & Hibiscus. & Pachistima ......... & \\
\hline$\ldots 59-60$ & $.53-61$ & $\ldots \ldots \ldots \ldots \ldots 69$ & .48 & \\
\hline is. ....51 & $\ldots 47-61$ & ngea paniculata & $\ldots 71$ & culata \\
\hline$\ldots 66$ & nia japonica... & lora.........54 & s...55 & $.57-62$ \\
\hline$\ldots 66$ & 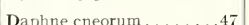 & Hypericum densiflor & $\cdots$ & \\
\hline$\ldots 51$ & $\begin{array}{l}\mathrm{Da} \\
\mathrm{D}\end{array}$ & & .56 & Taxi \\
\hline & $\begin{array}{r}a . .69 \\
\ldots .69\end{array}$ & 5 & $5-36$ & \\
\hline …6.67 & $\ldots \ldots 69$ & & $\ldots .32-34$ & edrys....62 62 \\
\hline$\cdots \cdots+6-51-52$ & Deutzia............ $53-54$ & Jasminum nudiflorum. & erti......60 & \\
\hline & Echinops...............69 69 & & $\ldots \ldots \ldots \ldots \ldots \ldots 1$ & Tradescantia........ \\
\hline $\begin{array}{l} \\
\cdots .676-52\end{array}$ & latus.61 61 & Kalmia ............... & (Picea) doug- & Isuga. . \\
\hline a.6. & hystinum, 69 & & Pueraria thunbergiana.....60 & Vacc \\
\hline & $\ldots \begin{array}{r}-47 \\
\ldots u m\end{array} 69$ &. .48 & & \\
\hline & $\begin{array}{l}\text { Eupatorium ceolestinum . .69 } \\
\text { Evodia Hupehense.......61 }\end{array}$ & $\because 48$ & Quercus... & Vinca minor. \\
\hline & & & Reti & \\
\hline $\begin{array}{l}\ldots \ldots 47 \\
\ldots \ldots 52\end{array}$ & & & & \\
\hline$\ldots 66$ & Gail & & Ros & Xanthorhiza.... \\
\hline & & & & \\
\hline erastium tomemtosum...67 & Halesia tetraptera.......28 & Lonicera . . . . . . .55-59-62 & Sagina sublata........ & Yucca filamentosa.... \\
\hline
\end{tabular}




\section{期osit $=\mathbb{C}$ ard}

\section{Do Not Forget}

to plant bulbs this fall for cheerful spring flowers

A Pleasing Assortment

36 TULIPS, both early and late, single and double

12 NARCISSI and DAFFODILS

Total -48 Choice, Hardy Bulbs

Special price, delivered ...... $\$ 2.50$

HOLM \& OLSON, Inc. FLORISTS

Nurserymen and Landscape Architects SAINT PAUL, MINN.

ASK FOR OUR FALL CATALOGUE

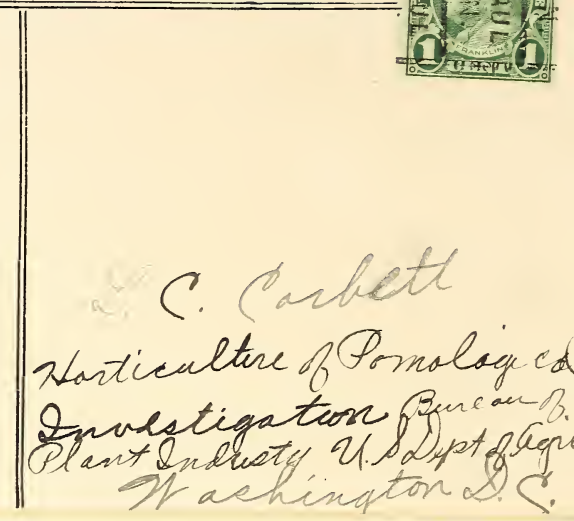




\section{LARGE TREE-MOVING DEPARTMENT}

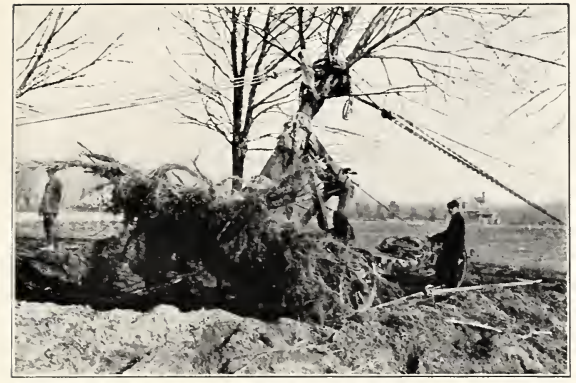

The main value to you is the wide spread of roots dissected out by skilled men under experienced foremen. The Hicks tree movers carry a full circle of roots 30 to 40 feet wide to most quickly make beautiful growth for you.

Moving a tree is a surgical operation. Moving a small tree is easy, because it has the recuperation of youth. It has its roots near by. It quickly re-establishes itself and gets normal balance. Moving large trees is difficult. We have overcome the difficulties and have trained and maintained since 1870 , staff, apparatus and knowledge for doing it right. The knowledge what not to move and the courage to tell you is our greatest value to you. This knowledge and courage to apply, is hereditary for generations, both in the office and in the field.

Maintenance, directions and inspections is of even greater value. It will pay to make monthly reports for the first two years of care given and moisture, drainage, mulching, growth. We cannot inspect all of them all the

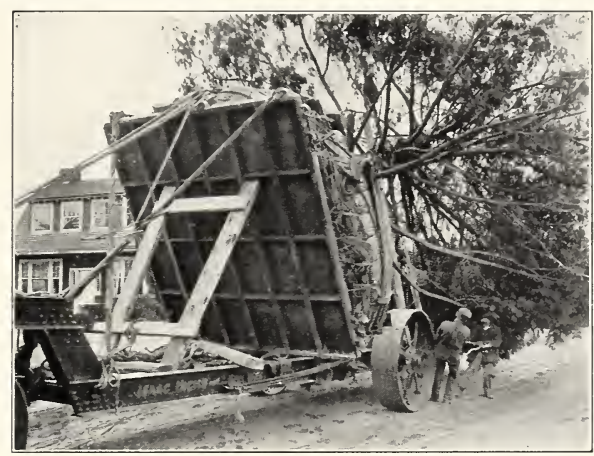

White Pine 50 years old moved from the Hicks Nurseries to the Church of the Advent, Westbury. Look at it. Trees selected and moved the Hicks way are good for a century.
Don't make the usual mistake of saying, "I want some big trees, come look through the woods, you certainly can find them." Trees crowded in the woods are very rarely worth moving. Trees in the open along the ditches and hedge rows are better, but it takes good judgment and years of experience to pick what is worth moving.

Have some of our experts to make a survey of your territory. Most people make the mistake of thinking near by is more economical than to go further and get better, that is, it is better to get a good tree on the right sol for good roots at 15 miles than a poor one at half a mile. Moving big trees is not an extravagance, it is creating beauty. Beauty is its own excuse for being. Moving large trees enables you to live off the country and arrange your landscape in harmony with your environment.

What is possible? Shade trees up to eighty feet high and sixty feet spread, 30 inches diameter at $3 \mathrm{ft}$.

What is practical? Shade trees up to sixty feet high and thirty feet spread because they can be tied in to go through most roads under the wires and bridges.

What is practical with evergreens? Pines, Spruce, Fir, Cedar, Hemlock, Holly thirty to fifty or sixty feet high, depending on root habits and soil formation and on the mutual protection and care which you will give. Moving an evergreen from a sheltered, moist situation to a dry, wind swept hill and expecting that it will continue its former beauty may be a mistake. Wind is the greatest enemy of evergreens; conversely, evergreens are the greatest enemy of wind and will do the most to shelter your home site, and make com fortable the playground of your children.

How is the work carried on? We will look over your problems and report what is best to do, maybe to ship by rail or truck equipment or tree moving apparatus, send a foreman with a crew to do the work. time.

Moving large trees was once thought to be a rich man's gamble. It is now very nearly a certainty, more nearly than small trees. Why? Because of our knowledge, apparatus, skill and nursing through the convalescence.

What do you want to do in moving big trees? Are there trees on your place that need thinning out? Send us a photograph or sketch and we can give preliminary opinion as to what is worth doing. We can visit your property, measure the trees, study local conditions and send you an estimate. Usually people wait too long to move out or cut out. Trees are not killed by waiting. but they lose part of their symmetry. We will tell you which are most likely to make permanently beautiful trees, which to cut back and which to cut out, which to move now and which to move later.

Come to the nursery, look over our various types of apparatus, see how perfectly they are adapted to the best handling of your trees, how skilfully the roots are dissected out and preserved and how quickly the men handle the apparatus. It is not a job to be done like digging a cellar, it is a surgical job, not cubic yards of earth to move.

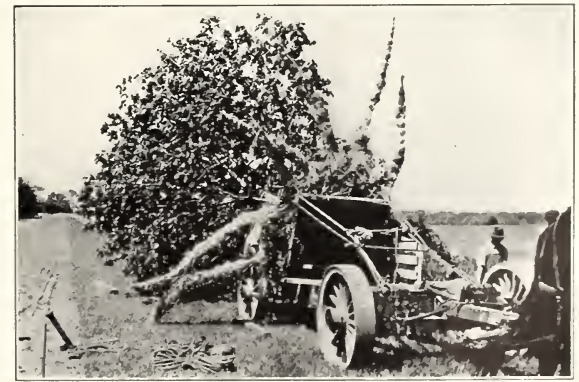

SUMMER PLANTING

Did you know that you can have a big shade tree in where you need shade? Come to the nursery, select the trees-maple, oak, linden, beech, 15-30 ft. high, and it's yours within a week.

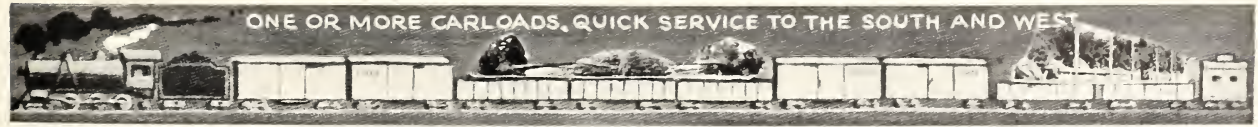

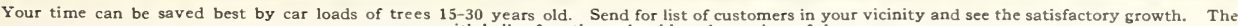
evergreens with balls of earth can be shipped any time of the year. 


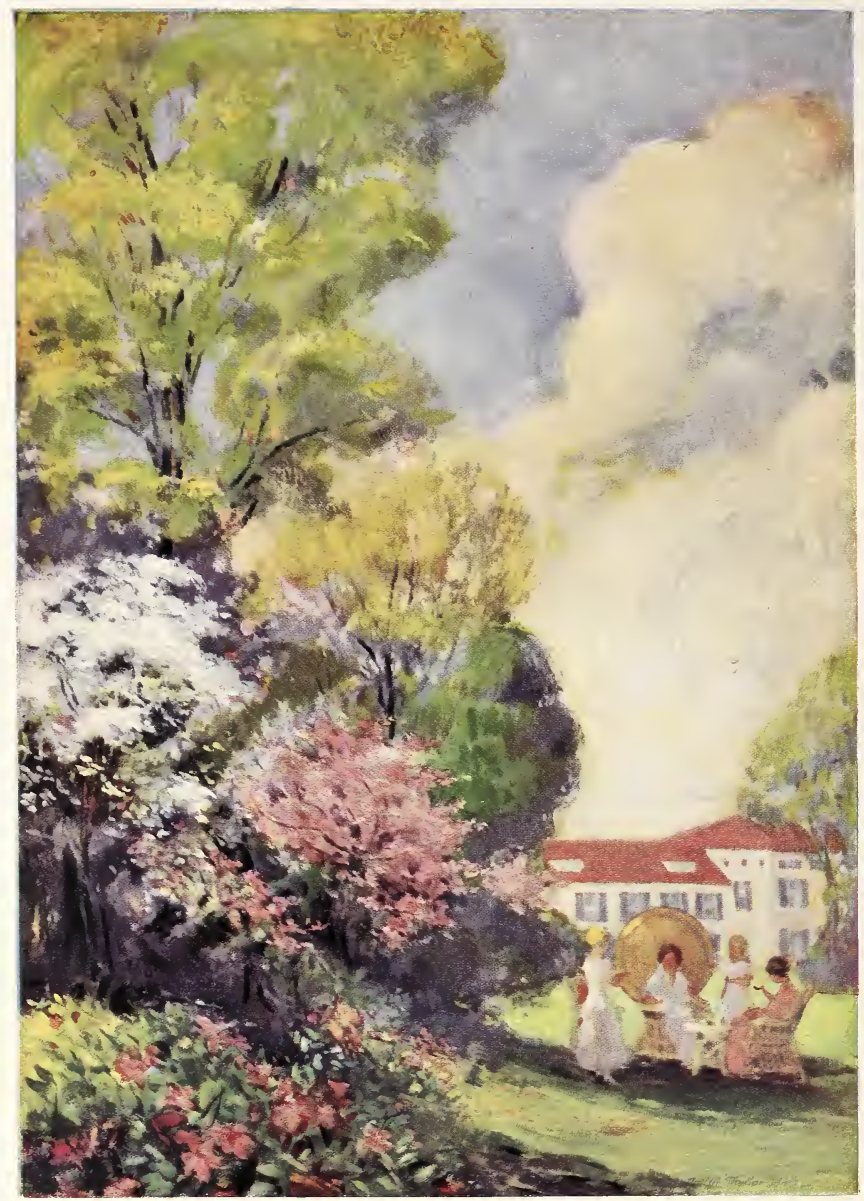

RED AND WHITE FLOWERING DOGWOODS. See page 3

\section{HICKS NURSERIES WESTBURY, LONG ISLAND}




$$
\text { P. }
$$




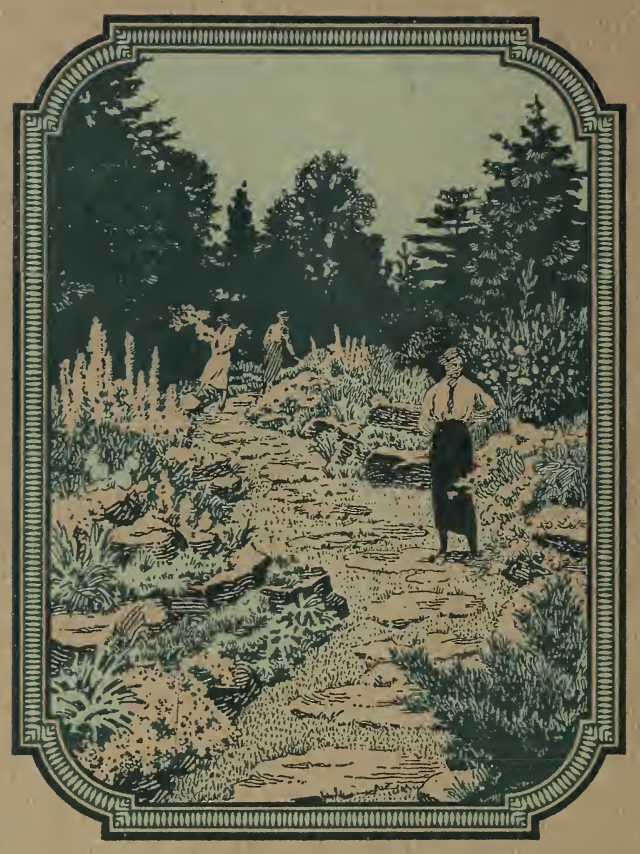

